\begin{abstract}
Title of Dissertation:

AN EXORBITANT PRIVILEGE IN THE FIRST AGE OF INTERNATIONAL FINANCIAL INTEGRATION

Carlos Eduardo Velmovitsky van Hombeeck, Doctor of Philosophy, 2016

Dissertation directed by: $\quad$ Professor John Joseph Wallis, Department of Economics
\end{abstract}

The exorbitant privilege literature analyzes the positive differential returns on net foreign assets enjoyed by the United States in the last quarter of the twentieth century as the issuer of the global reserve currency. In the first age of international financial integration (1870-1914), the global reserve currency of the period was the British pound sterling. Whether the United Kingdom enjoyed a similar privilege is analyzed with a new dataset, encompassing microdata on railroad and government financial securities. The use of microdata avoids the flaws that have plagued the US studies, particularly the use of incompatible aggregate variables. New measures of Britain's net external position provide estimates on capital gains and dividend yields. As the issuer of the global reserve currency, Britain received average revenues of 13.4\% of GDP from its international investment position. The country satisfied the necessary condition for the existence of an exorbitant privilege. Nonetheless, Britain's case is slightly different from the American one. British external assets 
received higher returns than were paid on external liabilities for each class, but British invested mostly in securities with low profile of risk. The low return on its net external position meant that, for most of the time, Britain would not receive positive revenues from the rest of the world if it were a net debtor country, but this pattern changed after 1900. The finding supports the claim that, at least partially, exorbitant privilege is a general characteristic of the issuer of the global reserve currency and not unique to the late twentieth century US. 


\title{
AN EXORBITANT PRIVILEGE IN THE FIRST AGE OF INTERNATIONAL FINANCIAL INTEGRATION
}

\author{
by \\ Carlos Eduardo Velmovitsky van Hombeeck \\ Dissertation submitted to the Faculty of the Graduate School of the \\ University of Maryland, College Park, in partial fulfillment \\ of the requirements for the degree of \\ Doctor of Philosophy \\ 2016
}

Advisory Committee:

Professor John Joseph Wallis, Chair

Professor Sebnem Kalemli-Ozcan

Professor Ethan Kaplan

Professor John Shea

Professor David Sicilia 
(C) Copyright by

Carlos Eduardo Velmovitsky van Hombeeck 2016 


\section{Preface}

This work unravels the lessons of history to illuminate modern puzzles. For most of human history, people from different locations needed a common currency to trade. For thousands of years, frequent candidates were assets with an intrinsic value. The most famous "barbarous relic" was gold, which served as a means of exchange until the beginning of the twentieth century. The creation of a new international financial system in the second half of the twentieth century elevated the dollar to the core of international transactions. Since then, economists have struggled to understand how the fiat money (money established by law) from one country can be accepted by other countries, as well as the benefits enjoyed by the issuing country. A particular subset of those benefits came to be known as "exorbitant privilege". This dissertation explains exorbitant privilege in a historical perspective, by comparing the benefits enjoyed by the US in the late twentieth century to the benefits enjoyed by the former issuer of the global reserve currency: Britain in the period 1870-1914. This work amalgamates three fields of economic literature: international finance, economic statistics and economic history. Statistics are a fundamental part of the process of reconstructing the financial environment of the period, in order to assess the importance of the pound sterling. I introduce a new database comprising almost the totality of the financial securities traded at the London Stock Exchange. The methodology to transform the dataset into statistics describing the British economy is also novel to the literature.

Chapter 1 introduces the main concepts related to exorbitant privilege and a simple accounting model that formalizes those concepts. The framework helps the 
understanding of the international finance literature that follows and the possible definitions of exorbitant privilege. Chapter 2 describes the economic environment of the end of the nineteenth century and beginning of the twentieth century. It also delineates the procedures utilized to reach the main results presented in chapter 3. Chapter 4 further analyzes and develops the results of chapter 3 in order to deepen the insights of the benefits enjoyed by Britain. Chapter 5 provides a detailed description of the data sources in order to facilitate its use in future research, as well as the specific procedures used for cleaning and organizing the data. Chapter 6 concludes. 


\section{Dedication}

Para Mariana, a coautora da minha alma, e todos os outros esquilos e passarinhos. 


\section{Acknowledgements}

Sir Isaac Newton, who also inadvertently introduced gold standard to Britain,

once wrote "If I have seen further than others, it is by standing upon the shoulders of giants". This quote applies perfectly to the effort of completing a $\mathrm{PhD}$ degree. Wide shoulders supported me indeed.

Firstly, I would like to acknowledge my advisor Professor John Wallis. I learned from him how to develop and express ideas and to think about the most important piece of knowledge: concepts. It has been a pleasure to interact almost daily with a rare specimen of human kind: a Big thinker, someone who is able to understand issues that affect us all. I will take for life the knowledge of American economic history and institutions. In fact, I hope to apply those lessons in Brazil one day, and help my country finally to cross the door from natural state to open access. In a more personal note, I enjoyed our long conversations about almost anything, from events in history to the current situations in many countries of the world. I am also thankful for at least three more things that I feel should be highlighted here. First, every time I talked to him, I left with the feeling that my ideas were much clearer in my mind. Second, he is willing to discuss the development of any idea, no matter how crazy it looks. Third, he always made it clear that I was welcome to work with him.

I would like to thank Professor John Shea, who was always available to talk and listen, treated every idea with respect and consideration. He had the incredible ability of tirelessly and carefully reading every manuscript I sent to him, contributing a great deal to their advancements. I owe him many great ideas and interesting developments of my work. 
Thanks to Professor Ethan Kaplan. I enjoyed many of our conversations, which always instigated me to think about concepts from a different and controversial perspective. I am also thankful that every time I talked to him, I left with the feeling that my ideas were much less clear in my mind, which is also very important.

I would also like to thank other faculty members: Professor Sebnem KalemliOzcan and Professor Allan Drazen. The two gave me great inputs along the way. From Professor Kalemli-Ozcan I acquired enormous knowledge of empirical international finance and passion for data. Her energy is an inspiration to me. Professor Drazen was a great supervisor for one year and another thinker I hope to emulate. My thanks go also to Professor David Sicilia, who gallantly accepted to be part of my committee.

A special thanks to the family of Professor Allan G. Gruchy. Their generous support in the form of a fellowship was a fundamental contribution to this work. Mark Wilkerson and Kim Fisher from Creekside Digital helped me in a particular fortuitous moment in connection to this. I will never forget their kindness.

Several people were very important in particular times of this journey. Vickie Fletcher and all the staff of the department of economics at UMD, Juliana Araujo, Antonio David, Chris Papageorgiou, Daili Wang and many others from the IMF, where I started to develop the idea for this work during two productive summers. Stéphanie Stolz, one of the dearest persons I have ever met, and all the people I interacted with during the fantastic period I spent in Frankfurt. My Chinese colleagues: An Wang (from Beijing...) and Qian Lu. I am grateful to them all, as well 
to three people who gave me an important first impulse to arrive here: Arminio Fraga, Professor Maria Cristina Terra and Professor Pedro Cavalcanti Ferreira.

My gratitude to the University of Maryland for the fellowships I received during the whole $\mathrm{PhD}$ program.

I am especially grateful to the members of my family. From my Barros side, my "amiga" Icléa, who was always vigilant and ready to help in big decisions at any time. My father-in-law Francisco, a source of wisdom and my official representative in the important political movements happening in Brazil at the time. Felipe and Simonetta, who were always a source of amusement. My father Charles, who is a warrior of life, an inspiration and a big part of who I am. My grandfather Charles, who kept his genuine kindness even after fighting a world war. My mother Riva, who was tireless in her visits, support, and caring for me. Finally, my beautiful and dear wife Mariana. This work is hers as well; she is the one who was beside me every second of the whole journey. The one who supported me through the moments of sadness, exhaustion or freezing weather. She is my true inspiration and the protagonist of all the joy of my life. The sounds, smells, tastes and colors of my reality. For her continuous support and love (and more), the deepest gratitude from my whole being. 


\section{Table of Contents}

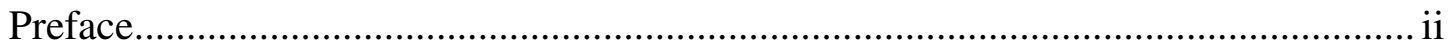

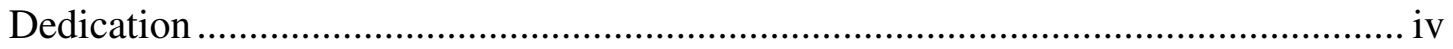

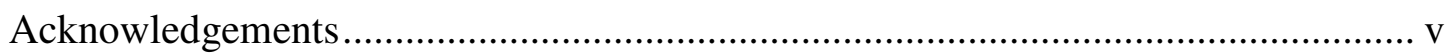

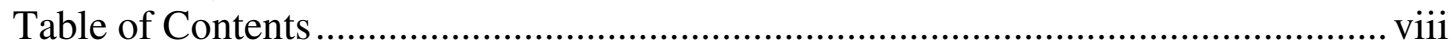

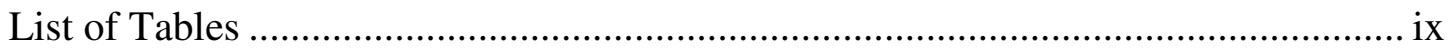

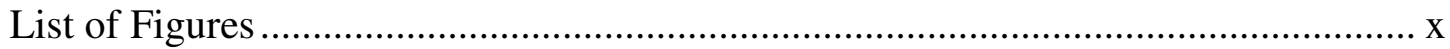

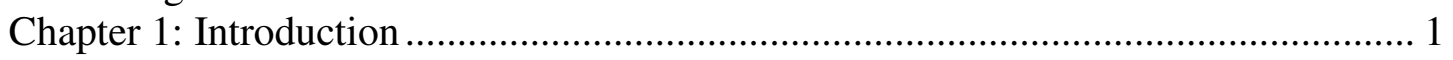

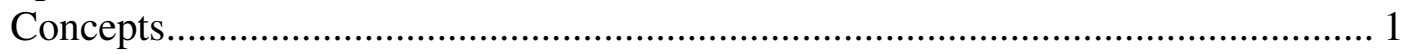

A simple model of external budget constraint accounting ................................. 9

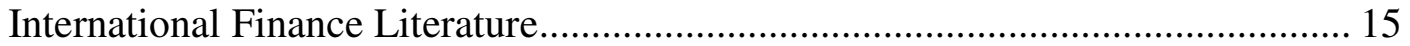

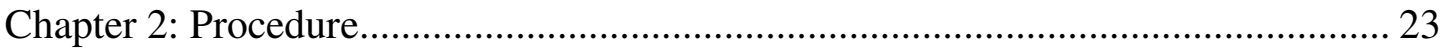

Background on the nineteenth century: The Gold Standard ............................... 23

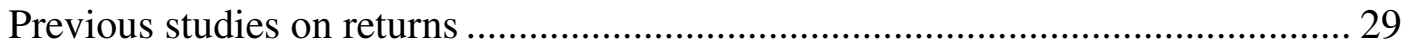

Procedure to build estimates of British external position and excess return .......... 32

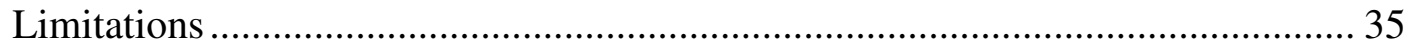

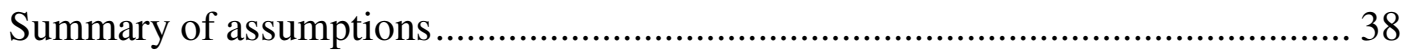

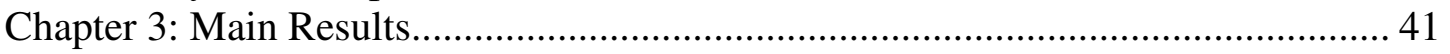

British International Investment Position ....................................................... 48

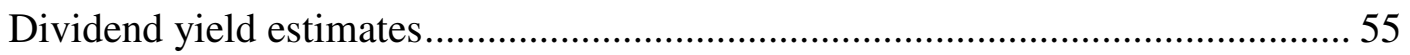

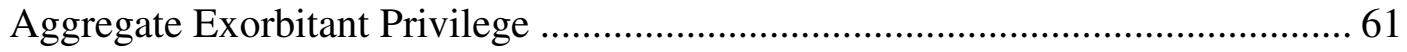

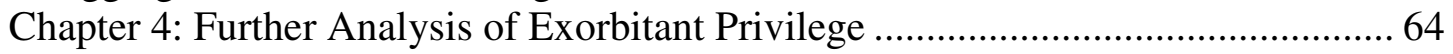

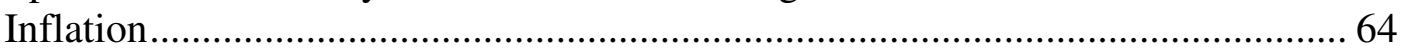

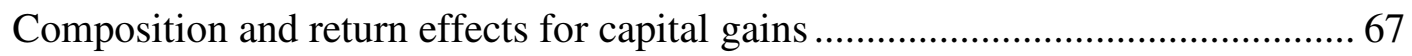

Separating between returns and aggregate positions ....................................... 73

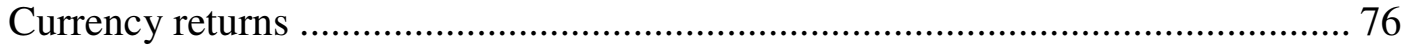

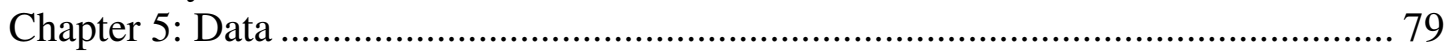

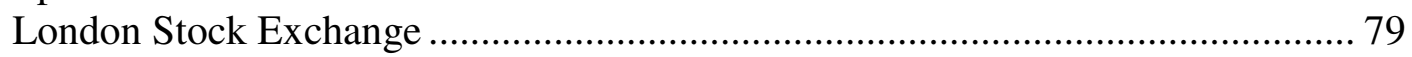

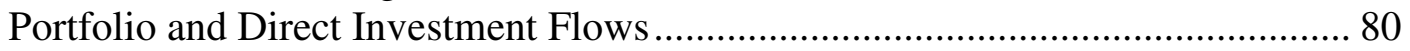

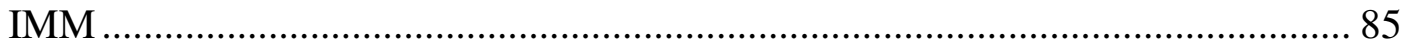

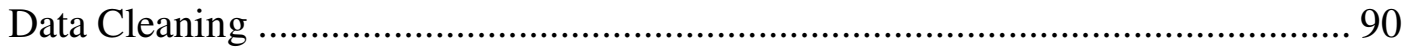

Variables Created ......................................................................................... 94

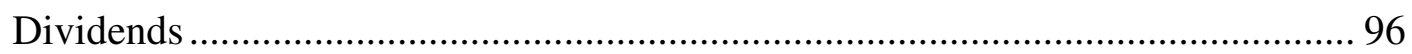

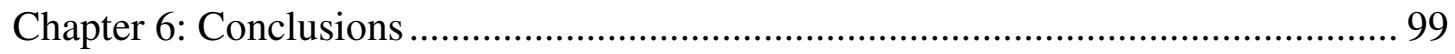

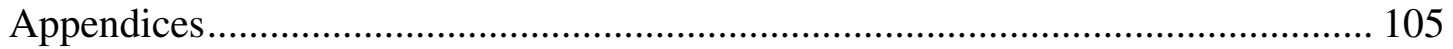

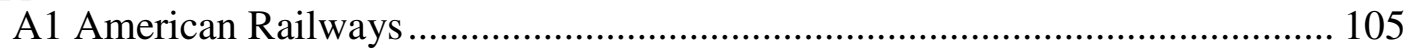

A1.1 A New Measure of US External Liabilities before WWI ..................... 111

A.2 Technical Appendix ............................................................................. 116

A2.1 Series under the same amount of capital........................................... 116

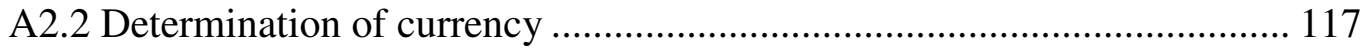

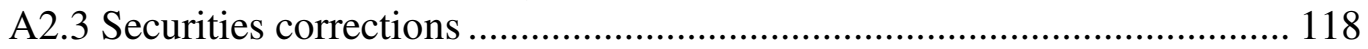

A3 Robustness for Calculation of Exorbitant Privilege.................................... 126

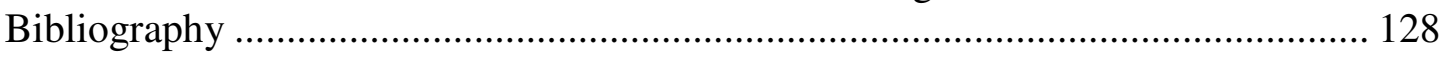




\section{List of Tables}

Table 1: Returns differential estimates from the international finance literature ....... 22

Table 2: Foreign Exchange Asset Holdings of Governments and Central Banks ...... 26

Table 3: Survey on the literature on returns of financial assets for $1866-1913 \ldots \ldots . . .30$

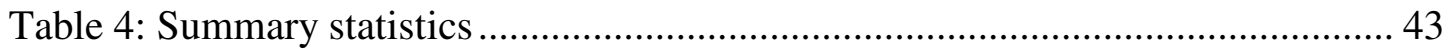

Table 5: Average yearly returns for each class of asset by decade........................... 72

Table 6: US External Liabilities: Comparison to figures from (Lewis 1975) .......... 115

Table 7: Exorbitant Privilege for the period 1869-1914 (\% of GDP): Variation in the ratio of ownership of British and Foreign securities............................................... 126 Table 8: Exorbitant Privilege for the period 1869-1914 (\% of GDP): Variation in the ratio of ownership of British and Foreign securities............................................ 127 


\section{List of Figures}

Figure 1: The exchange rate between US dollars and UK pounds sterling ............... 28 Figure 2: Average Distribution of British Investment for the period 1869-1914...... 46

Figure 3: Growth of the stock of British Investments............................................. 47

Figure 4: Value of outstanding foreign railroad and government securities .............. 50

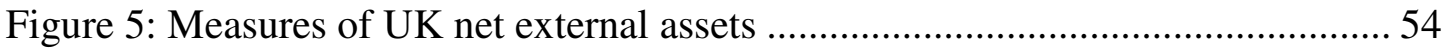

Figure 6: Dividend and coupon income on external assets and liabilities .................. 57

Figure 7: Average monthly excess return for 1869-1914 _.................................... 59

Figure 8: Average monthly railroad securities excess return for 1869-1914 .............. 60

Figure 9: Measure of net revenues earned by Britain (aggregate exorbitant privilege)

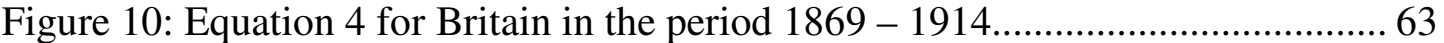

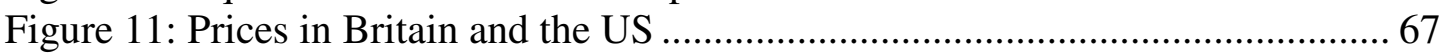

Figure 12: Composition of portfolios in terms of class of assets ............................... 69

Figure 13: Composition of average annualized monthly returns by year................... 73

Figure 14: Comparison of actual British Liabilities over Assets (1871 - 1914) to simulated British Liabilities over Assets with no income and US Liabilities over

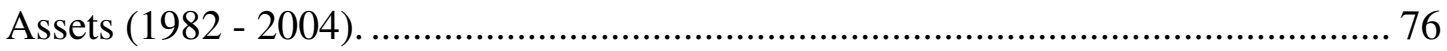

Figure 15: Measure of net revenues earned by Britain (aggregate exorbitant

privilege): breakdown between currencies. ....................................................... 77

Figure 16: Sample from the Investor's Monthly Manual....................................... 83

Figure 17: Sample from the Stock Exchange Yearbook of 1887 ............................... 84

Figure 18: Share of each country in total British railroads investments................... 106

Figure 19: Characteristics of American railroad securities...................................... 110

Figure 20: New series for American International Liabilities. .............................. 114

Figure 21: Comparison with series from Lane and Milesi-Ferretti (2007) and GR

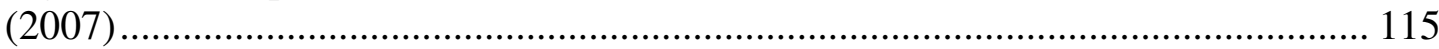




\section{Chapter 1: Introduction}

This chapter presents the main research question and the concepts related to the analysis of exorbitant privilege. The first section explains the concepts and their application to the case of Britain between 1870 and 1914. The basic concepts are then translated into a formal accounting framework. With the help of the accounting framework, the literature on exorbitant privilege is explored in order to provide a benchmark for the results of the next chapters.

\section{Concepts}

The main question I wish to answer is whether the UK enjoyed an exorbitant privilege when the pound sterling was the main international currency in the period 1870-1914. ${ }^{1}$ In order to answer this question, it is first necessary to define exorbitant privilege. There is no precise definition in the literature. The concept of exorbitant privilege was introduced as a way to explain particular characteristics of the US of the late twentieth century. The United States dollar has been the main international currency since the Second World War and the creation of the Bretton Woods framework. Exorbitant privilege derives from the US dollar's status as the main international currency: Over the postwar period the US has been able to borrow from

\footnotetext{
${ }^{1}$ The main international currency is often referred to as the global reserve currency. A reserve currency serves as a store of value in an international environment. A currency is selected as the preferred asset to save for a variety of reasons (financial sector development, institutions, military power, economic policies, importance in global trade, size of the economy, the lovely weather of a New Hampshire resort). The asset provides stable returns across states of nature or time. The currency is an instrument to acquire the safe asset, such as sovereign debt of the reserve country. In the last quarter of the twentieth century, US Treasury bills were regarded as the global safe asset and since they are traded in dollars, their demand translates into dollar demand.
} 
abroad at low rates and invest abroad at higher rates (in terms of yields and returns); the difference is its "exorbitant privilege."

Unlike Britain before the First World War, the US utilized this return differential to finance a persistent current account deficit. ${ }^{2}$ The main goal of the US literature was not to explain the origin of exorbitant privilege, but rather to take it as given and to assess how it affects the dynamics and sustainability of the US external accounts. The notion of exorbitant privilege explained a particular American phenomenon: the financing of extraordinary consumption as manifested by the current account deficit.

This work looks instead at the first age of international financial integration and financial account liberalization from 1871 to the outbreak of the First World War and the hegemon of that era, Britain, to assess if Britain also enjoyed an exorbitant privilege. The answer clarifies whether exorbitant privilege is a general characteristic of the issuer of the global reserve currency or if it is unique to the recent US. ${ }^{3}$ I reach the answer by estimating the net revenues received from Britain's external position.

To accomplish this, I need first to establish evidence of a positive return differential between securities issued in the main international currency and similar securities issued in other currencies. I call this primitive concept "pure" exorbitant privilege. The most direct way to verify whether this phenomenon exists is by

\footnotetext{
${ }^{2}$ For specific reasons explained in the next section, the return differential is also known as the valuation effect in the literature. On the United States, Gourinchas and Rey (2014) conclude: "Valuation effects (...) account for an important and increasing part of the dynamics of the net foreign asset positions of countries. For the U.S., valuation effects have tended to be positive and economically large."

${ }^{3}$ Since the dollar is the only reserve currency that has existed during the current period of financial integration, one contribution of this work is to add information about a new currency and an earlier historical period to the exorbitant privilege literature. The period from 1914 to 1945 saw a decline in financial integration due to two world wars and the Great Depression.
} 
comparing the returns of identical securities paid in both the main international currency and other currency. The analysis of this type of security allows us to roughly isolate the component of the return differential associated with the distinct currencies.

Two securities in the database possess this particular characteristic. Both were bonds from American railroads (the Allegheny Valley Railroad Company and the Cleveland, Columbus, and Cincinnati and Indianapolis Railway Company) payable either in gold/sterling or in dollars. The following excerpts were taken from the Stock Exchange Yearbook of 1869:

“Allegheny Valley Railroad Company - The amount was \$9,000,000 7\%, currency bonds of $\$ 1,000$ each; but to meet the natural dislike of this market to currency bonds, the Pennsylvania company, which guarantees both the principal and interest of these bonds, arranged that, at the option of the subscriber, both principal and interest should be paid in sterling, in which case, however, the interest was reduced to $6 \%$. (...) The price of issue was $88 \%$."

"Cleveland, Columbus, and Cincinnati and Indianapolis Railway Company The $£ 500,000$ consolidated mortgage bonds of $£ 200$ of this company, quoted in the official list, were issued in November, 1874, by Messrs. J. S. Morgan \& Co. The price was $£ 176$ per bond. Interest is payable the 1 st of June and December at the rate of $6 \%$, per annum in sterling, by the London agents, or at the rate of $7 \%$, per annum in currency, by the company, at New York, at the option of the holder."

Both of these railroad bonds show clear and direct evidence of a "pure" exorbitant privilege: exactly the same asset paying two different yields when interest is paid in different currencies. Suppose that instead of one bond with two options for 
currency of payment, there are two securities identical in every respect except for the currency in which interest and principal were paid. Comparison of yields of the two bonds gives us a direct estimate of the pure exorbitant privilege Britain enjoyed (at the level of individual bonds). American borrowers paid a 100 basis point premium to borrow in dollars rather than sterling or gold.

Securities that are payable simultaneously in two currencies, however, are rare. The usual solution is to calculate the average return on securities issued by one country (mostly denominated in the currency of that country) and compare it to the average return on similar securities issued by other countries. On average, British securities paid less 200 to 300 basis points in comparison to similar foreign securities.

The next step of the analysis is to estimate the aggregate effect of pure exorbitant privilege: is the positive return differential strong enough to affect macroeconomic variables, such as those of the external accounts? If macroeconomic variables are affected, the country enjoys "aggregate" exorbitant privilege. To analyze aggregate exorbitant privilege, it is useful to introduce an intermediate concept: "weighted" exorbitant privilege. Both weighted and aggregate exorbitant privileges are derived from the definitions of external assets and liabilities.

Countries usually interchange goods and services. Commercial relationships give birth to financial relationships. One example is a country that buys goods from Britain and has to pay in pounds sterling. In order to obtain sterling pounds, the country may accumulate sterling pounds from previous sales to Britain. The (decreasing) international reserves from the country are international assets for the country and international liabilities for Britain. The country may also arrange to 
borrow sterling pounds from a British bank. The amount lent will be part of Britain's international assets as well as part of the international liabilities of the other country. In addition to financial relationships derived from commercial relationships, countries may engage in pure financial relationships. For example, a British investor buys a farm in Brazil. The farm represents an asset to the British investor and a liability to Brazil. It is usually the case that the external liabilities of the country that issues the main international currency are primarily denominated in the main international currency (US treasuries are denominated in dollars). ${ }^{4}$ Since its assets (the Brazilian farm) are denominated in currencies of other countries, the currency compositions of external assets and liabilities are different, with external assets mostly denominated in other currencies and external liabilities mostly denominated in the global reserve currency. Since pure exorbitant privilege implies that a security denominated in the global reserve currency pays a lower return than a similar security denominated in other currency, the portfolio composed of Britain's external assets receives a higher return than the portfolio composed by British external liabilities. ${ }^{5}$

"Weighted" exorbitant privilege is simply the calculation of a weighted average of securities' returns, using as weights the shares of the securities in the overall external assets and liabilities, since different types of assets may enjoy different pure exorbitant privileges. If, as in the case of the US, external assets and

\footnotetext{
${ }^{4}$ The stylized fact that the international liabilities of emerging markets are also denominated in the main international currency (and not in their national currencies) is called "original sin" in the literature. See Eichengreen, Hausmann and Panizza (2007) for a review.

${ }^{5}$ I am not arguing that the aggregate positive returns differential is caused by currency composition. I am simply stating that an aggregate positive return differential exists. Several factors, such as depreciation risk, military power, legal system, and volatility might explain the positive returns differential.
} 
liabilities have similar magnitudes, the weighted average on returns is a good proxy to the revenues that the country receives from the rest of the world. For example, if a country that issues the global reserve currency has external assets and liabilities of $100 \%$ of GDP and the weighted exorbitant privilege is $2 \%$ (the difference between the weighted returns on assets and weighted returns on liabilities is two percentage points), the country will receive $2 \%$ of GDP of revenues from the rest of the world. Different compositions of the asset or liability portfolios compound different returns, generating a stronger or weaker aggregate result.

Aggregate exorbitant privilege depends on the composition of the country's asset position (weighted exorbitant privilege), as well as on the absolute size of the country's external positions. Large gross foreign asset and liabilities positions amplify the revenues generated by the security premium received by the country that issues the international currency. ${ }^{6}$ Rogoff and Tashiro (2015) argue that "To the extent a country (say the United States) does enjoy higher rates of return on foreign assets than it pays on comparable liabilities to foreigners, then it can earn a profit by "grossing up" the size of its balance sheet in much the same manner that a hedge fund does." The final result of the "grossing up" is aggregate exorbitant privilege. In the example above, the issuer country received $2 \%$ of GDP, but if its external assets were $200 \%$ of GDP instead of $100 \%$, the aggregate exorbitant privilege could jump to

\footnotetext{
${ }^{6}$ The expression "security premium" is used interchangeably with "positive return differential". While both refer to the difference in yields between securities quoted in the main international currency and securities quoted in other currencies, "security premium" implies that the difference in yields is related to the status of the main international currency as a tool to acquire the safe asset. The security premium concept is not related to seigniorage. It is useful to compare the country issuing the reserve currency to a monopolist that charges a mark-up for its output, in this case the safe asset. Since it faces a more elastic demand for its assets than other countries, the issuer of the global reserve currency is able to issue a large amount of debt without significantly affecting its interest rate.
} 
$6 \%$ of GDP (using weighted returns on assets of $4 \%$ and weighted returns on liabilities of 2\%).

Another example elucidates how exorbitant privilege relates to the dynamics of the US external account in the late twentieth century. Consider a country with a current account deficit of $3 \%$ of GDP, gross external assets of $100 \%$ of GDP and external liabilities of $200 \%$ of GDP (which means that the country is a debtor with a net external position of $-100 \%$ of GDP). If the capital gain on assets is $4.5 \%$ and the capital gain on liabilities is $0.5 \%$, and if yields on assets are $1.6 \%$ and on liabilities $0.3 \%$, this country would still receive positive net resources from the rest of the world equal to $0.5 \%$ of GDP. The positive return differential between assets and liabilities (pure exorbitant privilege) is large enough to outweigh the debtor position of the country. The return differential manifests itself as an aggregate exorbitant privilege and it interferes with the dynamics of the external accounts since it means that this country accumulates less external liabilities than in the absence of the phenomenon.

Periods of high financial integration such as 1870-1914 and the last quarter of the twentieth century are characterized by the ease of performing commercial and financial transactions between countries. The greater the number of financial transactions between countries, the larger the amounts of external assets and liabilities exchanged between countries and the size of exorbitant privilege to the issuer of the global reserve currency.

Keynes (2004) described the level of financial (and commercial) integration of the global economy prior to 1914 and the centrality of Britain to it: 
"The inhabitant of London could order by telephone, sipping his morning tea in bed, the various products of the whole earth, in such quantity as he might see fit, and reasonably expect their early delivery upon his doorstep; he could at the same moment and by the same means adventure his wealth in the natural resources and new enterprises of any quarter of the world, and share, without exertion or even trouble, in their prospective fruits and advantages; or he could decide to couple the security of his fortunes with the good faith of the townspeople of any substantial municipality in any continent that fancy or information might recommend."

The level of financial integration declined sharply after 1914 and would not be reached again until the second half of the twentieth century. Britain was the core of the global economy from 1871 to 1914 and the pound sterling was the main international currency. London was the financial center of the world and the main channel through which British exported capital (an average of 5\% of GDP annually). Estimates of the net external position of Britain before the First World War are controversial, but fall in a range between $120 \%$ and $160 \%$ of GDP. ${ }^{7}$

Why is the separation between pure and aggregate exorbitant privilege necessary? To apply the analysis of the recent US literature to Britain, it is necessary to disentangle both concepts. Since Britain's current account was not in deficit for most years, the pure exorbitant privilege manifested itself in the export of capital. I do not explain the origin of pure exorbitant privilege. Rather, I take it as a historical fact

\footnotetext{
${ }^{7}$ A large literature devoted to the question of the long-term impact on growth of the export of capital asks if British investors acted rationally by sending capital abroad instead of investing in domestic industries. This issue is not discussed in detail here. Important references are McCloskey (1970), Kennedy (1974) and Crafts (1979).
} 
to be documented, but want to measure the existence of the aggregate counterpart, a replication of the literature for the US.

The standard practice in the existing literature is to assess the existence of an aggregate exorbitant privilege with respect to GDP as an empirical measure. I require a measure of the total returns on the British portfolio to perform such a calculation. Because aggregate data is not available for pre-1914 Britain, I use a dataset based in individual assets. The lack of aggregate data, however, is a blessing rather than a curse. The flaws that plague the existing exorbitant privilege literature stem from the use of incompatible sets of aggregate data. By building estimates of external positions from underlying microdata on flows, prices, and yields of securities, I avoid these flaws. Another advantage of using historical data is that it describes a less complex financial period than the last quarter of the twentieth century and allows the calculation of aggregate variables without the large resources available to modern official statistical agencies. The data presented here has been used in the economic history literature on the British export of capital, but I apply it in a novel way to estimate the net external asset position of Britain. ${ }^{8}$

\section{A simple model of external budget constraint accounting}

The discussion of exorbitant privilege is filled with different concepts and definitions. Since the literature evolved from the analysis of a specific case (the US), most of its conclusions are entangled with idiosyncratic American characteristics. I need a simple formal representation of variables at issue to compare in a clear way

\footnotetext{
${ }^{8}$ Since this new version of the data is a useful resource to the field of international finance, I include an explanation of historical sources and discuss the methods used to produce estimates of British external positions during this period.
} 
the estimates made for the US with the ones I construct for Britain. I need to distinguish between price variables (capital gains and yields) and stock variables (the international assets and liabilities of countries) to disentangle pure and aggregate exorbitant privilege. Simple definitions derived within the accounting framework encapsulate both concepts.

The general accounting framework for the net foreign asset position is based on Lane and Milesi-Ferretti (2007) and Habib (2010). The net foreign position of a country for period $t$ can be written as $N F A_{t}=A_{t}-L_{t}$, where $A_{t}$ denotes the stock of gross external assets and $L_{t}$ the stock of gross external liabilities. The change in the net foreign position can be decomposed into its main determinants:

$$
\begin{gathered}
\text { Equation } 1 \\
N F A_{t}-N F A_{t-1}=C A_{t}+K G_{t}
\end{gathered}
$$

The change in the net foreign position is equal to the current account balance (CA) plus $K G$, the capital gain or loss. ${ }^{9}$ The valuation component $K G$ is the key to transforming the underlying flows $C A$ into changes in stocks $\left(N F A_{t}-N F A_{t-1}\right)$. It can be defined as the result of changes in asset prices $(P)$ and exchange rates $(e)$ at which assets and liabilities are valued at the end of each period:

\footnotetext{
${ }^{9}$ The fundamental identity of balance of payments accounting is $C A_{t}+F A_{t}=0$. As explained in the previous section, the origin of international investment positions are the flows of the financial account $(F A)$. The capital account (a small item in the balance of payments encompassing capital transfers) and 'errors and omissions' are ignored.
} 


\section{Equation 2}

$$
\begin{gathered}
K G_{t}=\sum_{i}\left[\left(\frac{P_{t}^{i} e_{t}^{i}}{P_{t-1}^{i} e_{t-1}^{i}}-1\right) A_{t-1}^{i}\right]-\sum_{j}\left[\left(\frac{P_{t}^{j} e_{t}^{j}}{P_{t-1}^{j} e_{t-1}^{j}}-1\right) L_{t-1}^{j}\right] \\
=k g_{t}^{A} A_{t-1}-k g_{t}^{L} L_{t-1}
\end{gathered}
$$

$A^{i}$ and $L^{j}$ represent the $i$ securities that compose gross external assets and $j$

securities that compose gross external liabilities. ${ }^{10}$ An example of the equation above is an American investor that buys a Brazilian stock for 100 dollars in January. If that stock is trading at 120 dollars in February, the investor had a capital gain of $20 \%$. If the stock is trading at 80 , the investor had a capital loss of $20 \%$. If the stock is trading at 120 in February, but the investor bought the stock in January at an exchange rate of 1 dollar to 1 Brazilian real and in February the exchange rate depreciates to 1 dollar to 2 Brazilian reais (the plural of real in Portuguese), the investor had a capital loss of $40 \%$ (gains of $20 \%$ originating from price variation and losses of $50 \%$ originating from the exchange rate movement).

The current account $C A$ equals the sum of the balance on goods, services and current transfers $(B G S T)$ and the investment income balance $I B_{t}=i_{t}^{A} A_{t-1}-i_{t}^{L} L_{t-1}$,

\footnotetext{
${ }^{10}$ This procedure of price updating is called mark-to-market. This is a standard procedure for the calculation of a country's international investment position, as formally described in the International Monetary Fund Balance of Payments Manual (BPM). Version 6 of the BPM states: "Positions of financial assets and liabilities should, in general, be valued as if they were acquired in market transactions on the balance sheet reporting date. Many financial assets are traded in markets on a regular basis and therefore can be valued by directly using the price quotations from these markets". This message is even clearer in the previous version of the Manual: "In principle, all asset and liability stocks comprising a country's international investment position should be measured at market prices. This concept assumes that such stocks are continuously (regularly) revalued---for example, by reference to actual market prices for financial assets such as shares and bonds or, in the case of direct investment, by reference to enterprise balance sheets".
} 
where $i^{A}$ and $i^{L}$ are the nominal yields on assets and liabilities. ${ }^{11}$ Denoting ratios to GDP $(Y)$ with lowercase letters, we can express equation 1 as:

\section{Equation 3}

$n f a_{t}-n f a_{t-1}$

$$
=\frac{i_{t}^{A} A_{t-1}-i_{t}^{L} L_{t-1}+k g_{t}^{A} A_{t-1}-k g_{t}^{L} L_{t-1}}{Y_{t}}+b g s t_{t}-\frac{\gamma_{t}}{\left(1+\gamma_{t}\right)} n f a_{t-1}
$$

where $\gamma$ is the growth rate of nominal GDP.

One potential consequence of pure exorbitant privilege is that $k g_{t}^{A}>k g_{t}^{L}{ }^{12}$

Since there is a positive return differential between securities quoted in the main international currency and securities quoted in other currencies, this condition must also hold in average or aggregated terms. Yields on investments $\left(i_{t}^{A}, i_{t}^{L}\right)$ are also a component of equation 3. Depending on the type of asset, the positive spread between returns on assets and liabilities can occur in dividends, coupon payments or earnings on direct investment that can be incorporated in the equation as $k g_{t}^{A}+i_{t}^{A}>k g_{t}^{L}+$ $i_{t}^{L}$. Differently from capital gains represented by $\mathrm{kg}$, yields are periodical flows and only affect external liabilities and assets to the extent that they are reinvested.

Two definitions of aggregate exorbitant privilege are common in the literature. ${ }^{13}$ The first is that the US income balance of the current account is positive

\footnotetext{
${ }^{11}$ The component compensation of employees that is usually included in the income balance is small if compared to investment income. It can be included instead in BGST.

${ }^{12}$ This is weighted exorbitant privilege, since pure exorbitant privilege applies to individual assets. $k g_{t}^{A}>k g_{t}^{L}$ is a weighted average of pure exorbitant privileges, according to equation 2 .

${ }^{13}$ See the description of Gourinchas and Rey (2007) in the next section. McCauley (2015) explains several concepts of exorbitant privilege, including seigniorage. The discussion that follows relates directly to his concept (4), although is also linked to his concepts (1) and (3). A usually neglected topic contained in the discussion is the role of adverse selection when foreign firms acquire American assets: "Cross-border acquisitions in the competitive US market for corporate control do not get the pick of the litter and are often divested."
} 
despite the country being an international debtor since 1988. This holds if $\left(L_{t-1} / A_{t-1}\right)>1$ and $i_{t}^{A}>i_{t}^{L}\left(L_{t-1} / A_{t-1}\right)$. The second is that there is a significant positive difference between the constructed net asset position and the cumulated current account series. By solving equation 1 backward for past values of $N F A$ and assuming that $N F A_{0}=0$, the result is $N F A_{t}=\sum_{i=0}^{t} C A_{i}+\sum_{i=0}^{t} K G_{i}$. If $N F A_{t}>$ $\sum_{i=0}^{t} C A_{i}$, then $\sum_{i=0}^{t} K G_{i}>0 .{ }^{14}$

By requiring that $n f a_{t}-n f a_{t-1}>b g s t_{t}$, or that in each period the variation in the net foreign asset position is greater than the flows of good, services and transfers, I reach a definition of aggregate exorbitant privilege encompassing most of the definitions stated before:

$$
\begin{gathered}
\text { Equation } 4 \\
\left(k g_{t}^{A}+i_{t}^{A}-\gamma\right)>\left(k g_{t}^{L}+i_{t}^{L}-\gamma\right)\left(L_{t-1} / A_{t-1}\right)
\end{gathered}
$$

This equation might be complemented by $b_{g s t}<0$. In the case of the US in the last quarter of the twentieth century and the UK in the period 1871-1914, BGST is negative. In both cases, the relation $i_{t}^{A} A_{t-1}>i_{t}^{L} L_{t-1}$ holds, and in the case of Britain $i_{t}^{A} A_{t-1}>i_{t}^{L} L_{t-1}-B G S T_{t}{ }^{15}$ None of the expressions depends directly on the sign of $A-L$, but some expressions are function of the ratio $L / A$. This means that exorbitant privilege can occur in a country with a positive net external position $((L / A)<1)$ as

\footnotetext{
${ }^{14}$ Since the first definition of the literature states that $I B>0$, this condition can also be rewritten as $N F A_{t}>\sum_{i=0}^{t} B G S T_{i}$. Gourinchas and Rey (2007) state the second definition in terms of GDP. The correct procedure would be to use equation 3 to get $n f a_{t}>\sum_{i=0}^{t}\left(b_{g s t} /(1+\gamma)^{t-i}\right)$. Since their paper is mostly based on graphical analysis, it seems possible that they used instead $n f a_{t}>\sum_{i=0}^{t}\left(C A_{i} / Y_{i}\right)$. Despite being the first work to use the expression "exorbitant privilege", it provides no formal definition. Their introduction contains a vague explanation: "For some, it refers to the fact that the US's income balance has remained positive all these years, despite mounting net liabilities. For others (...) exorbitant privilege referred to the ability of the US to run large direct investment surpluses, ultimately financed by the issuance of dollars held sometimes involuntarily by foreign central banks."

${ }^{15}$ Since 1876, the trade balance was mostly in deficit, while the current account remained in positive territory due to the so-called "invisible" account given by services and income.
} 
in Britain. In the case of the US, liabilities are greater than assets $(L / A>1)$.

The literature has used the concepts above with the objective of finding a characteristic that could single out the issuer of the global reserve currency. Habib (2010) plots net external positions, cumulated BGST, cumulated investment income balance $\left(i_{t}^{A} A_{t-1}-i_{t}^{L} L_{t-1}\right)$ and cumulated $K G$ for six countries from 1980 to 2007 . He finds that the US is the only country that presents a consistent pattern of positive $K G$ and investment income balance. Australia, Argentina and Brazil have negative investment income balances, while Germany and Japan (surplus countries) have negative capital gains. Gourinchas and Rey (2014) find that for the period 1970 to 2010, Germany, Japan, Russia, India and China present negative capital gains, while the figure is mixed for Brazil and UK.

The concepts presented in this section will permeate the discussions of this work. In chapters 4 and 5, most of the analysis of pure and aggregate exorbitant privilege follows the literature and relates to the conditions $k g_{t}^{A}+i_{t}^{A}>k g_{t}^{L}+i_{t}^{L}$ and the condition from equation 4 . These conditions constitute intuitive criteria for exorbitant privilege, not a decomposition of the causes of the phenomenon. The paper by Rogoff and Tashiro (2015) contains an important qualification to the last point:

"The broader definition, of course, confounds many different phenomena, not all of which can necessarily be thought of as "privilege" ${ }^{16}$ If a US company builds an auto plant in a risky and unstable emerging market, a high return might be regarded as compensation for taking a greater risk than a foreign company that invests in the US

\footnotetext{
${ }^{16}$ They adopt two definitions of exorbitant privilege. While the narrowest definition includes only securities issued by the government of the country that issued the main international currency, the broader definition encompasses cost advantages for all types of investment instruments.
} 
market."

\section{International Finance Literature}

All the existing references of the international finance literature use aggregate data to build estimates of net external positions and exorbitant privilege. The reason for the use of aggregate data is the unavailability and complexity of the underlying microdata. One example of how the use of aggregate data can be problematic is related to the price-updating of previous stocks of investments (as explained in the definition of $K G_{t}$ in the previous section) by general price indexes. American equity investment in Brazil is heavily concentrated in commodities companies. If the Brazilian stock index is instead concentrated in telecommunications companies, and the prices of stocks of telecommunications companies increased less than those of commodities companies, a measure of capital gains for American equity investment in Brazil based on the overall Brazilian stock index would underestimate the true figure.

Meissner and Taylor (2008) is the only previous discussion of exorbitant privilege for Britain from 1870 to 1914. Their paper draws lessons from history with respect to the future dynamics of the financing of the US current account deficit. According to their work, Britain realized a diminishing privilege over the pre-war period. They estimate returns by regressing the income account on the net external position of Britain. Since there are no official figures for the British net external position during this period, they use an estimate from Imlah (1958) originally backed out from the income accounts, which corresponds to the stock of assets that results in the observed income account for a chosen rate of return. By construction, Meissner 
and Taylor's estimated rate of return must equal Imlah's chosen rate of return, as the authors acknowledge. In the end, the authors rely primarily on prior evidence from the literature on returns, specifically Davis and Huttenback (1986). ${ }^{17}$

The first attempt to estimate the net external position in the United States (and other countries) for recent years was Lane and Milesi-Ferretti (2001), followed by revisions and extensions in Lane and Milesi-Ferretti (2007). They tackle the lack of data on external assets and liabilities by constructing estimates of $K G_{t}$ since 1970 based on aggregate country data. They estimate the initial stock value of the components of the balance of payments as of 1970 and accumulate flows from there (going backwards or going forward), adjusting for prices. The price adjustment term $(\mathrm{kg})$ is estimated at the aggregate level using generic measures of prices. In their original paper, for example, equity assets are adjusted by the Morgan Stanley Capital Index and equity liabilities by national stock market indexes. They assume that equity external asset positions of all countries are the same and that the portfolio of external liabilities is the same as the composition of national stock market indexes. Their original paper also adjusts for the composition of external assets and liabilities in terms of currencies. Their second paper uses additional data (such as the IMF's Coordinated Portfolio Investment Survey) to improve and extend the original estimates, but relies on the same methodology.

Gourinchas and Rey (2007, hereafter GR) examine the US case more closely. Gross external asset and liability series are constructed by updating aggregate data with generic indexes of prices and exchange rates, using aggregate data for each class

\footnotetext{
${ }^{17}$ More explanation on historical sources is presented in chapters 2 and 5.
} 
of investment such as equity, debt, direct investment and other. Their main objective is to highlight the role of the US as a leveraged financial intermediary (short in shortterm and fixed-income securities and long in external equity and direct investment) at the center of the international financial system. Related to this special position, GR define exorbitant privilege through the two puzzles mentioned above (a positive US income balance despite the country being an international debtor and the positive difference between the constructed net asset position and the cumulated current account series). The first is the "income puzzle" and the second the "position puzzle".

GR also present a useful decomposition of excess returns (returns on assets minus returns on liabilities) into two channels when explaining what is unique about the US external position. Defining $r^{i}=i^{i}+k g^{i}$ as total returns for $i=(A, L)$ and $\alpha_{j}$ and $\lambda_{j}$ as the weights of each investment class $j$ (equity, debt, direct investment and other) in total assets and liabilities, the difference in total returns may be directly decomposed as:

$$
\begin{gathered}
\text { Equation 5 } \\
r^{A}-r^{L}=\sum_{j} \frac{\left(\alpha_{j}+\lambda_{j}\right)}{2}\left(r_{j}^{A}-r_{j}^{L}\right)+\sum_{j}\left(\alpha_{j}-\lambda_{j}\right) \frac{\left(r_{j}^{A}+r_{j}^{L}\right)}{2}
\end{gathered}
$$

The first term on the right-hand side is the total return effect. It refers to the fact that the US usually receives a higher return on its assets than it pays on its liabilities for each class of assets. For this channel, since only returns are being compared, the portfolio positions of assets and liabilities are not relevant. This is the most important channel explaining the advantageous external position for the US.

The second term on the right-hand side is called the composition effect. The US external assets are composed mainly of FDI and equities, investments with higher 
risk (and return). In contrast, debt, bank loans and trade credit dominate the US

foreign liabilities. These different compositions are compounded by the currency

composition of assets and liabilities. Given the returns on individual asset classes, the

different compositions of assets and liabilities generate different aggregate returns.

For the period 1973-2004, the excess return received by the US was $3.3 \%$, with $2.4 \%$

coming from the return effect and $0.9 \%$ from the composition effect.

The most recent contribution to the core of the exorbitant privilege literature is

Curcuru, Thomas and Warnock (2013, henceforth CTW). ${ }^{18}$ They show that

differences among various estimates (from GR and the following literature) for the

excess returns in the US come from the use of different databases that are

inconsistent. Specifically, existing estimates of $K G$ in equation 1 are calculated based

on the existing series of $N F A$ and $C A$, but the $N F A$ statistics contain a residual term

$O C$ (other changes) that is possibly related to missing flows. The inclusion of this

term in the calculation generates biased estimates of excess returns. ${ }^{19} \mathrm{CTW}$ argue that

\footnotetext{
${ }^{18}$ Other previous references are the subsequent work of Gourinchas, Rey and Govillot (2010) and Habib (2010). In the first paper, the time coverage of the original database was extended to include the recent crisis period. The US transferred wealth to the rest of world during the crisis, which is the expected offsetting duty from the benefit received during tranquil times. Habib (2010) compares the US to 48 other countries for the period 1981-2007. He concludes that indeed the US exhibits exorbitant capital gains when compared to other countries, and confirms the importance of the return effect. More recently, Rogoff and Tashiro (2015) analyze the case of modern Japan and conclude that the world's largest creditor (for many years) and second largest market economy also enjoys exorbitant privilege. The case of Japan is particularly suitable to be compared to Britain, since both countries maintained current account surpluses and positive net external position. A precursor of the exorbitant literature with the name "dark matter" is Hausmann and Sturzenegger (2006).

${ }^{19}$ According to CTW, NFA and $C A$, "which have completely different revisions policies and come from different data collection systems, are not consistent with one another." and "discrepancies in estimates of returns differentials owed in large part to past BEA (Bureau of Economic Analysis) policies of regularly revising positions, rarely revising flows, and never publicly releasing revisions to valuation adjustments." CTW also quote statisticians of the BEA: "'Other changes' are changes in position that cannot be attributed to price changes, exchange rate changes, or financial flows... it is unlikely that significant price or exchange rate changes have been erroneously included in "other changes"... it is far more likely that financial flows that could not be identified from revisions to position estimates have been commingled with statistical changes in the 'other changes' category."
} 
a more accurate estimate of the excess return for the period 1990-2011 is $1.8 \%$, but the value varies considerably with the chosen time interval. Their estimates for the two channels are:

- Composition effect. Measurement of the composition effect is not controversial, since the difference in composition between US external assets and liabilities is clear, but its contribution to the returns differential is smaller than previously estimated. Their estimate for the period 1990-2011 is only $0.1 \% .^{20}$

- Return effect. Using corrected data, the total return differential is smaller than previously estimated. Capital gains are only $1.6 \%$ for assets and $1.2 \%$ for liabilities over the period 1990-2011. The yield differential $\left(i_{A}-i_{L}\right)$ is responsible for the major part (1.4\%) of the total return differential.

The direct consequences for the two puzzles are:

- The income puzzle is driven exclusively by yields on direct investment. Differences on returns on direct investment between US assets and liabilities are high for several reasons. Of the total direct investment earnings differential of $5.6 \%$, the authors estimate that at least $2.4 \%$ comes from genuine reasons, such as direct investment assets being riskier and more mature than direct investment liabilities. On the other hand, at least $1.8 \%$ comes from a technical illusion created by the accounting of direct investment assets before tax and liabilities after tax.

\footnotetext{
${ }^{20}$ The sample period is an important source of variation of estimates, as GR (2014) indicate. Nonetheless, since the net external position of the US was more negative in the nineties than in the seventies, the comparison between the two results is still possible, which means that CWT would find a smaller result if they included in their sample years going back to 1970 or 1952 .
} 
- Position puzzle. Since CTW's estimate of differences in capital gains is smaller than previous estimates, the explanation for the difference between net external assets and the cumulated current account must reside somewhere else. CTW find that valuation adjustments (updated to solve the compatibility problems between balance of payments and international investment position statistics) still explain the greatest part of the gap. They also correct for statistical discrepancies between the current and financial accounts. In theory $C A_{t}+F A_{t}=0$, but in practice measurement errors and omissions mean that an error term $E_{t}$ exists $\left(C A_{t}+F A_{t}+E_{t}=0\right)$. Since the origin of international investment positions are the flows of the financial account $(F A)$, using $C A$ as a proxy for $F A$ is acceptable as long $E$ is small.

The most important contribution of CTW is to assimilate work done by statisticians from the Bureau of Economic Analysis (BEA), the official compilers of the American data used in previous papers. Using aggregate data to estimate different macro phenomena can be perilous, since the original data may not be suitable for that purpose. Since the calculations of aggregate variables are marked by extreme and increasing complexity, the only group capable of accessing the underlying (and large) data and knowledgeable enough to treat and adapt it is the one that produced those statistics in the first place.

Table 1 merges table 3 from GR (2014) and tables 1, 2 and 3 from CTW (2013). The range for estimates for differences in total returns (capital gains plus yields) is wide, going from 0.6 to 6.9 , depending on the specification of error terms and period of estimation. This broad range is a reflection of the fact that the aggregate 
data utilized by the majority of authors is not suitable to answer the questions of interest. For example, the estimates from GR (2014) for the period 1973-2011 range from $2 \%$ if $O C$ is allocated as missing flows to $3.8 \%$ if $O C$ is allocated as valuation. GR (2014) also compile their estimate for the US valuation component as a share of GDP, ranging from $0.84 \%$ for the period $1971-1980$ to $4.75 \%$ of GDP for the period $2001-2010$.

The estimates presented for the US in Table 1 and the previous paragraph provide the main basis of comparison to the results obtained to Britain in the period 1870-1914. The estimates presented for the US utilize aggregate data and are rough approximations for the return differential, an important caveat, while my estimates for Britain are more precise, since they are built from microdata. I discuss the procedures leading to the estimates for Britain in the next chapter. 


\begin{tabular}{lcc}
\hline Source & Period & Difference in Returns \\
\hline Obstfeld and Rogoff (2005) & $1983-2003$ & 3.1 \\
GR (2007) & $1973-2004$ & 3.3 \\
Lane and Milesi-Ferretti (2007) & $1995-2004$ & 2.7 \\
Meissner and Taylor (2008) & $1981-2003$ & 3.7 \\
CTW (2008) & $1990-2007$ & 1.1 \\
Curcuru, Dvorak, et al. (2008) & $1994-2005$ & 0.72 \\
Lane and Milesi-Ferretti (2009) & $1983-2007$ & 0.6 \\
Forbes (2010) & $2002-2006$ & $4.6-6.9$ \\
Habib (2010) & $1981-2007$ & 3.4 \\
Gourinchas, Rey and Govillot (2010) & $1973-2009$ & $1.6-3.5$ \\
CTW (2013) & $1990-2011$ & 1.9 \\
GR (2014) & $1973-2011$ & \\
Gohrband and Howell (2015) & & \\
\hline \hline
\end{tabular}

Table 1: Returns differential estimates from the international finance literature. Main sources are CTW (2013) and GR (2014). 


\section{Chapter 2: Procedure}

This chapter delineates the procedure I use to calculate the British external position and the revenues originating from it. The calculation of revenues is the main component of the estimation of aggregate exorbitant privilege presented in the next chapter. Description of the procedure is followed by a discussion of its limitations. Two sections contain a discussion of the role of pound sterling under the gold standard and a presentation of evidence from the financial history literature on the existence of pure exorbitant privilege, a necessary condition for the existence of aggregate exorbitant privilege. $^{21}$

\section{Background on the nineteenth century: The Gold Standard}

In the nineteenth century, the international monetary system was the gold standard. Under this system, countries fixed the prices of their domestic currencies in terms of a specified amount of gold, which meant that exchange rates were fixed. Since gold was the core of the system, a question immediately arises: Was the actual reserve currency in the late nineteenth century gold, with the pound sterling only being a close substitute? In that case, gold would benefit from the extra demand generated by its status as the global reserve asset, affecting positively the price of the

\footnotetext{
${ }^{21}$ This work will not analyze an important difference between the US and UK, the existence of colonies. Because of the inherent condition of colonies, the metropolis derives extraordinary income from direct political control. The literature on Imperialism (the economics of empire) is extensive. Foreman-Peck (1989) does not find evidence of extraordinary income from India, the most important British colony after American independence. Davis and Huttenback (1986), in their definitive work, conclude that colonies did not represent an outrageous source of net revenues to Britain. In conclusion, the return differential with respect to colonies was not significantly different from what the British enjoyed in relation to other countries.
} 
metal. $^{22}$ Gold producers would enjoy this valuation effect, meaning that Britain and the pound sterling per se would not enjoy an exorbitant privilege. A summary of the history and the mechanism of the gold standard clarifies this question and explains the role of the pound as a reserve currency independent from gold. ${ }^{23}$

Britain officially ended the monetary role of silver in 1821 . By the last quarter of the nineteenth century most other European countries had converted to the gold standard. The US first entered the system in 1834 and abandoned it in 1933. The Civil War caused the suspension of the gold parity and the issuance of greenbacks between 1862 and 1879. The US returned to the gold standard de facto in 1879 . Formal legislative recognition did not come until 1900, and in the interim there was a constant threat that silver might be included in the US monetary base. Britain abandoned the gold standard in 1931 after a suspension between 1914 and 1925 .

The first classical description of the gold standard was Hume (1752). While on the gold standard, central banks (or monetary authorities) issued only currency backed by gold. In order to buy goods from another country, a person would convert their national currency into gold to pay the foreign seller. The seller would return to his country and convert the gold into his national currency. In this sense, there was a direct link between the balance of payments of the country and the monetary base. A country that was importing more than exporting had to send gold abroad to pay for

\footnotetext{
${ }^{22}$ The safety aspect is natural, since gold is a metal with intrinsic value. The pound sterling would be safe only to the extent of its interchangeability with gold, in which case sterling would be an ersatz reserve currency.

${ }^{23}$ Chapter 2 of Eichengreen (1998) provides more details.
} 
the deficit. Because of gold outflows, the monetary base shrank and the price level fell, making the local products cheaper and automatically closing the external gap. ${ }^{24}$

This description is very simplified and tied entirely to trade flows. The inclusion of financial markets adds complexity. Exporters and importers used bills of exchange to finance the movement of goods. The exporter received a bill of exchange from the buyer and discounted it at the local bank. The bank would send this bill through a network of banks to the buyer's bank in a foreign country. There, the buyer would accept the bill and pay for it. Banks would sell and buy bills of exchange going in both directions, reducing the necessity of sending gold physically. Gold was shipped to cover net flows, not gross flows and only for persistent imbalances over time. Bills of exchange were denominated in the currency of the largest financial houses of the time, located in Britain. Other financial flows were also important. Besides bills of exchange, investors could buy bonds, equities, and insurance. For example, British investors bought assets such as American land and securities, and arbitraged the market price of gold and the official rate in different locations. ${ }^{25}$

The actual usage of gold varied in two other dimensions:

1. In a small group of core countries (Britain, France, Germany and the US) gold coins constituted a large part of money in circulation. In most other cases (the

\footnotetext{
${ }^{24} \mathrm{~A}$ technical detail is the fact that gold had a dual role as a monetary conduit and as a commodity. Jones and Obstfeld (2004) distinguish between monetary and non-monetary gold flows. Gold traded as a commodity is a current account transaction, but, if exchanged for monetary purposes, it is a capital (or financial) flow.

${ }^{25}$ Another departure from the classical framework is that central banks could speed up or slow down the adjustment process. By changing the discount rate at which they discounted bills of private banks, the monetary authorities managed credit and price levels without triggering gold movements. This policy was referred to as the rules of the game. One important qualification is that those open market operations were only feasible in countries with liquid markets. Not surprisingly, the most powerful monetary authority of the time was the Bank of England.
} 
periphery), a large share of the money supply circulated in the form of paper and other materials. These countries were on the gold standard because their central banks or equivalent institutions stood ready to convert money into gold at a fixed price.

2. Countries also held different compositions of international reserves. While the core countries maintained primarily gold as international reserves, others kept their international reserves in the form of currencies of countries that were convertible in gold and had strong credibility. Countries such as India, Japan and Russia earned a positive yield on their reserves by keeping them in the form of British Treasury bills or bank deposits in London.

Table 2 shows that sterling-denominated assets were the preferred asset of official institutions when excluding gold. ${ }^{26}$

\begin{tabular}{ccccccc}
\hline \hline Year & Gold & Sterling & Francs & Marks & Other & Total Non-Gold \\
\hline 1899 & - & 105.1 & 27.2 & 24.2 & 9.4 & 246.6 \\
1913 & 4846.2 & 425.4 & 275.1 & 136.9 & 55.3 & 1124.7 \\
\hline \hline
\end{tabular}

Table 2: Assets Holdings of Governments and Central Banks (USD Millions). The residual between total non-gold and the sum of currencies is unknown allocation. Source: Lindert (1969).

\footnotetext{
${ }^{26}$ The figures from Lindert (1969) show that official (central banks and governments) foreign exchange reserves amounted to 22\% of official gold reserves in 1913 (when excluding Britain, which held the largest official gold reserves after the US. For obvious reasons, pounds sterling were not held as international reserves by Britain). This figure is almost surely underestimated since the author lacks data for foreign exchange reserves for many countries. The author does not have estimates for gold reserves in 1899. For 1880 and 1903, they were one billion dollars and 2.6 billion dollars respectively.
} 
The gold standard was a fixed exchange rate regime, with the direct consequence that valuation effects coming from exchange rate dynamics were minimal. From 1879 (after the greenback period in the US) to 1914, the annual average of the most important exchange rate at the time (US dollar to pound sterling, also known as "the cable") was very close to the official rate of 4.85 dollars per pound sterling with an annual standard deviation of only 2 cents (see Figure 1). Some countries offered additional safety for British investors. In Brazil, a government profit-guarantee system abolished exchange rate risk for foreign investors, as explained by Abreu (2000). Although there was no government guarantee in the United States, investors in American companies were able to obtain similar guarantees against exchange rate risk, during the period when coinage of silver was under discussion, by purchasing securities denominated in pounds sterling. Because of those factors the capital gains arising from exchange rate variation are small in the sample analyzed in this paper. 


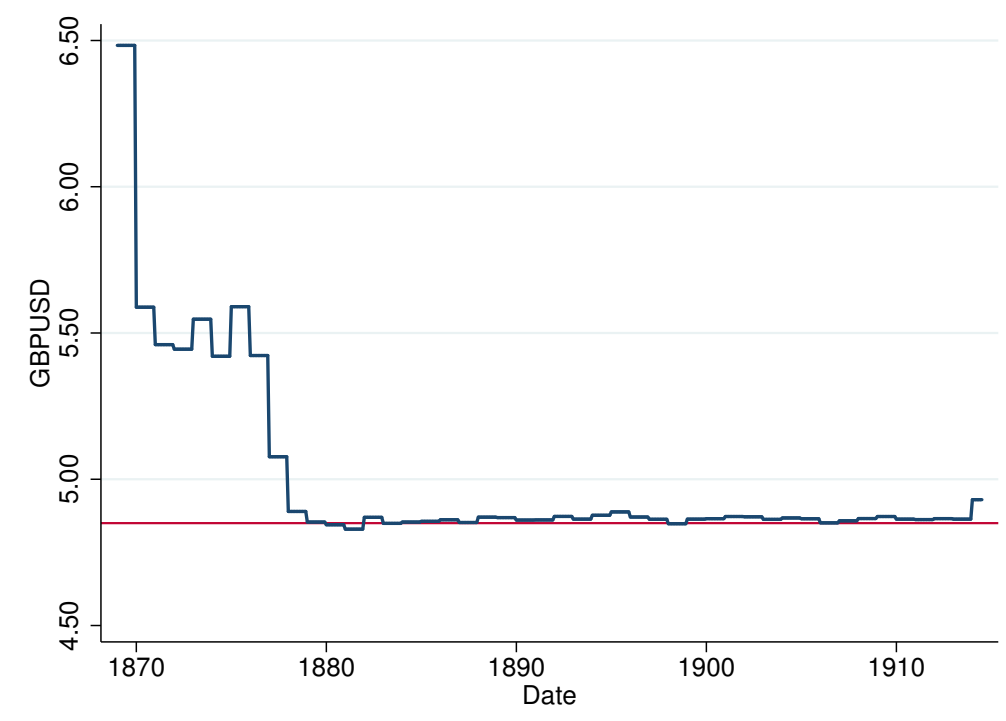

Figure 1: The exchange rate between US dollars and UK pounds sterling (dollars per one pound sterling).

While gold was the core of the monetary system of the nineteenth century, a large superstructure of financial arrangements and transactions surrounded it. Britain's central position in global finance, trade and industry meant that the British financial markets were the most liquid and sophisticated in the world. The direct consequence was that British assets and the pound sterling assumed a major independent role in the international financial system. Instruments denominated in pound sterling composed the international financial superstructure. While gold was a settlement currency, the pound sterling was the global reserve currency. The fact that the majority of financial assets were denominated in pounds and that countries held international reserves in the form of pounds meant that the pound enjoyed an exorbitant privilege even in the presence of gold. Those additional sources of demand increased the liquidity and safety premium of sterling denominated assets and translated into additional demand for pounds sterling. 
The complementarity between financial flows (in the form of infrastructure lending) and the predominance of Britain in capital goods exports further strengthened the special position of the pound sterling. All these factors contributed to create a unique environment of advantageous financing conditions to British investors. British investors responded to this advantage by exporting capital and this enhanced the initial favorable sterling position even further.

\section{$\underline{\text { Previous studies on returns }}$}

Several studies have analyzed the returns on British investment in the nineteenth century to determine whether British investors were acting rationally when they invested resources abroad rather than at home. The export of British capital is one of the main characteristics of capital flows in the nineteenth century. This branch of the economic history literature has already generated estimates of return differentials.

Table 3 contains a summary of estimated return differentials in the literature (explained below), with each reference containing different samples of coverage and classes of securities. The exact numbers differ across authors but two patterns are clear. Equity returns are higher than debt returns. More importantly, British assets paid a lower return (capital gain plus yield) than comparable assets from other countries for each class of asset (with one exception). In the particular case of government bonds, Chabot and Kurz (2010) find that the return on foreign assets is twice that for UK bonds. Assets from the United States seem to yield a higher return than average. Looking at the last column of the table, the same is true for France (note that Edlinger, Merli and Parent (2013) do not provide returns on French debt). This is 
evidence that Britain benefited from a pure exorbitant privilege.

\begin{tabular}{|c|c|c|c|c|c|}
\hline Authors & $\begin{array}{r}\text { Edelstein (19 } \\
\text { Goetzmann and Ukh }\end{array}$ & 2006) & Chabot and Kurz & $(2010)$ & Edlinger et al (2013) \\
\hline \multirow{9}{*}{ Assets } & UK Debt & 3.346 & UK Government Bonds & 2.906 & $3.52-5.05$ \\
\hline & $\begin{array}{c}\text { UK Equity } \\
\text { UK Preferred }\end{array}$ & $\begin{array}{c}6.608 \\
5.01 \\
\end{array}$ & $\begin{array}{l}\text { UK Corporate Bonds } \\
\text { UK Corporate Stocks }\end{array}$ & $\begin{array}{l}3.982 \\
4.660\end{array}$ & $3.81-13.89$ \\
\hline & Foreign Equity & 8.663 & $\begin{array}{c}\text { Foreign Corporate Stocks } \\
\text { US Stocks }\end{array}$ & $\begin{array}{l}7.13 \\
8.39 \\
\end{array}$ & $5.02-9.28$ \\
\hline & & & Foreign Government Bonds & 5.89 & \\
\hline & Foreign Debt & 4.945 & Foreign Corporate Bonds & 6.03 & $5.01-5.17$ \\
\hline & & & US Bonds & 6.86 & \\
\hline & & & & FR Equity & $4.51-12.33$ \\
\hline & & & & Foreign FR Debt & $6.24-9.43$ \\
\hline & & & & Foregn FR Equity & 9.32 \\
\hline Period & $1870-1913$ & & $1866-1907$ & & $1875-1913$ \\
\hline
\end{tabular}

Table 3: Survey on the literature on returns of financial securities for $1866-1913$

(FR means France).

Curiously, even though this literature has used information on prices of British assets and flows of investments originating from Britain, no one has gone a step further and connected these two series to build an international investment position.

Edelstein (1982) collected data on returns and used portfolio optimization techniques to conclude that British investors received a higher return from overseas investments than domestic ones. Goetzmann and Ukhov (2006) argued that British investors were aware of the benefits of diversification even if they lacked a formal theory. Using modern portfolio theory, they conclude that foreign debt and equity presented a high return when compared to their domestic counterparts. Furthermore, the inclusion of foreign assets in the British portfolio improved the risk-return characteristics of the portfolio frontier. One of the interesting conclusions of their paper is that British investors would have benefited from investment overseas because of the diversification of assets, even if average returns had been similar to 
domestic returns. In most cases, if short sales were allowed, the authors found that rational investors should have shorted UK debt (generally defined) to invest in foreign assets.

Chabot and Kurz (2010) apply the same techniques to an expanded monthly database collected from several sources. ${ }^{27}$ Their new database includes 2242 stocks and 1817 bonds negotiated in London or the US. They also find that foreign asset returns dominated domestic returns. Given the imperfect correlation between domestic and foreign assets, the inclusion of foreign assets expanded the meanvariance frontier. This is further confirmed by tests showing that foreign assets were not spanned by domestic assets. The inclusion of foreign assets could increase the utility of a British investor by $10 \%$ to $89 \%$, depending on parameters used in the utility function. Grossman (2015) uses Investor's Monthly Manual data to build several regional and sectoral equity indices for the London Stock Exchange between 1869 and 1929. Finally, Edlinger, Merli and Parent (2013) add French data on portfolio allocations and find that the inclusion of more European securities made French allocations more balanced. This means that British investors should have included more European assets to achieve an optimal allocation, given the investment opportunities at the time.

The general conclusion of the literature is that, from the point of view of modern capital flow theories, British investors lacked home bias and behaved according to neoclassical models by sending capital to where it obtained the highest return.

\footnotetext{
${ }^{27}$ Money Market Review, Investor's Monthly Manual, The Economist, Commercial and Financial Chronicle's, Mining Record and Records of Stock Brokers and Stock Exchanges.
} 


\section{Procedure to build estimates of British external position and excess return}

The source of the new data presented in chapter 5 is the Investor's Monthly Manual (IMM) from 1869 to 1914, a monthly publication providing information on all the securities traded on the London Stock Exchange (LSE) for the pre-WWI period, including stocks and bonds. For each security, the data set contains three groups of data that are relevant to calculate the international investment position: financial flows $(F A)$, prices $(P)$ and dividend yields $(i) . F A$ and $K G$ (calculated from $F A$ and $P$ ) are directly available from one consistent data source. Rather than working back from aggregate data, estimates are built up from micro-data. Since prices and stock positions are available for each individual security, aggregation problems such as the previously mentioned example of commodities and telecommunications companies are absent: the same securities that compose the stock index compose the price index.

The procedure ties together three separate steps: the calculation of aggregate capital flows, the estimates of net external positions (as in Lane and Milesi-Ferretti (2007) and other sources, including the IMF and official compilers), and finally the calculation of aggregate exorbitant privilege. To understand how I generate data on external assets, consider the following example:

- A British investor buys a security issued by a foreign firm on the London Stock Exchange (LSE). This represents a portfolio flow from Britain to the receiver country $(F A)$. The flow gives birth to a liability from the receiver's side and an asset from Britain's side that constitutes a stock (in the sense of a quantity of something accumulated for future use - NFA). My assumption is 
that the stock of British investors' holdings for each security is given by a proportion of the total (or nominal) stock of capital listed for that security at the LSE.

- Once the stock of each security is determined, and given the issuance price for each security $\left(P_{0}\right)$, it is possible to update the value of this stock by the stream of market prices $\left(\left\{P_{t}\right\}_{t=1}^{T}\right)$ for each month since the security was issued (or since the data is first available). As an example, if a security is issued at a price of 90 pounds and the price rises to 99 in the second month, the investor earns $10 \%$, since in an organized market such as the LSE he could sell the security at the quoted price at any moment. These prices are used to measure the capital gains $(\mathrm{kg})$ or valuation effects. ${ }^{28}$

- If the investor holds the security until maturity, he receives the security's face value (or nominal value). In the example, the investor would receive 100 pounds. This represents a reverse flow from the country that initially received the investment to Britain and reduces the stock of Britain's external assets.

- Depending on the type of security, the investor is entitled to receive periodic flows of money before the date of maturity. Those are the dividend or coupon

\footnotetext{
${ }^{28}$ The issuance price is usually different from the security's face value or nominal price. Since securities were usually quoted in terms of receivables of 100 pounds, in the example the security issuance price represents a discounted value with respect to the nominal face value. Some securities were sold at par value (or even at a premium over face value) and the capital gain was realized at the end of the life of the security, since the investor received a premium over face value (in this case the issuance price is the face value and the capital gain is given by the difference between "withdraw price" and the face value). With respect to debt securities, the coupon rate is an important component of the discussion, since the issuance price is related to the difference between the coupon rate offered by the security and the market rate. A discount of the issuance price relative to face value usually implies that the security's coupon rate was below the initial market interest rate, since the capital gains coming from the difference between the nominal value and the issuance price would offset the lower coupon rate.
} 
yields $(i)$, which affect the current account but do not directly affect the external asset position of Britain. An exception is dividends paid with new securities.

- The total return is the combination of the capital gains and the dividend or coupon yield.

- British external liabilities are calculated by using the stock of capital of British securities bought by foreign investors, following the same steps described above.

After the aggregation of all securities, two series are constructed. The first is the sum of the capital value of each outstanding security for each period, measured at issuance prices. This is the issuance price series. The second is the sum of the capital value of each outstanding security for each period, measured at current market prices (updated by $\left\{P_{t}\right\}_{t=1}^{T}$ ). The last series is a proxy for the British external position. The valuation component $K G$ is given by the difference between the issuance price series and the current market price series. The composition effect of Equation 5 can be assessed from the stock positions for each class of security while the return effect can be measured from the total returns given on assets and liabilities by price variations and dividend yields. The procedure builds up from microdata on individual financial securities. Another beneficial aspect is that the British external position is calculated directly from the financial flows $F A$, avoiding problems with respect to errors and omissions of the balance of payments and in line with the suggestions of Borio and Disyatat (2015). 


\section{$\underline{\text { Limitations }}$}

Several qualifications are necessary. First, since the direction of the investment flow on the LSE is from Britain to other countries, it is clear that the data can be used only to construct an estimate of Britain's external assets. The calculation of Britain's external liabilities and exorbitant privilege requires knowledge of the stock of British securities held by foreigners, and my estimates rely on imputed values. ${ }^{29}$ I assume that foreigners held $20 \%$ of the nominal capital stock of British securities traded at the LSE, meaning that those securities belonged to UK external liabilities. British investors dominated the markets for British railroad and government securities during the period, but this assumption makes an allowance for foreign agents buying British assets on the London Stock Exchange. It is still possible to estimate the total return effect from the IMM data without additional assumptions, since prices and yields for British securities are available.

Second, as already mentioned, foreign investors used the LSE to buy foreignissued securities. Assuming that the total capital for each foreign-issued security was bought exclusively by British investors would lead me to overstate British external assets. A large literature addresses this issue in order to reach an overall figure for the stock of British assets on the eve of the First World War. The main challenge is that there is no record of the ownership of nominee holdings of bonds (the most popular security), due to the popularity in London before 1914 of "bearer" bonds

\footnotetext{
${ }^{29}$ With regard to Britain's external liabilities, preliminary evidence indicates that they started growing after 1900 in connection to the financing of expenditures related to the Second Boer War, possibly by bonds or bank loans. While the government was borrowing from abroad, the country as a whole was still exporting capital. Data on British external liabilities may be available from counterparts. Examples are Abreu (2006) for Brazil, Stone (1977) for Latin America and Lewis (1975) and Wilkins (2009) for the US. Nonetheless, Meissner and Taylor (2008) boldly affirm, "British net external assets roughly equaled gross external assets, and Britain became a very large net creditor".
} 
(payable simply to "bearer" without further specification). As for stocks, Davis and Huttenback (1986) (cited by Davis and Gallman (2001)) collect data from a random sample of corporations required to file equity structure statements, including addresses of stockholders. The sample contains 260 firms registered between 1883 and 1907, 75 with their principal operations outside Britain, and 79,944 stockholders. They select reports made three to five years after registration to avoid capturing the original owners of the firms. The result is that $82.9 \%$ of the stockholders of foreign firms listed on the LSE were located in the UK (76.7\% in England alone). For UK firms, the figure is $99.4 \%$ and the total average (including also the separate category Empire) is $89.5 \%$. Of course, the total average can mask large variations between sectors, as pointed out by Kindersley (1929) for the period after the Great War (admittedly an event that constitutes a structural break). Platt mentions that "foreign government stock (sovereign bonds) was almost certainly held by foreigners to the extent of 30-40\% before the First World War" and his overall estimate for securities held by foreigners is $15 \%$. For this reason, I also make an allowance for foreign agents buying foreign assets at the LSE and assume that British investors held only $80 \%$ of the nominal capital stock of foreign railroad securities and $60 \%$ of the nominal capital stock of foreign sovereign securities traded on the LSE.

Third, it is also possible that British investors bought foreign-issued securities in stock exchanges outside Britain. Not taking this flow into account understates the British external asset position, which is the mirror of the previous problem. As already mentioned, the LSE possessed a competitive and regulatory advantage with respect to other countries' stock exchanges. Markets in Berlin and Paris were highly 
regulated by each government. Davis and Cull (2002) provide an extensive comparison between the LSE and the New York Stock Exchange (NYSE) for the time, and conclude that the NYSE's institutional arrangements led companies seeking capital to the LSE. Finally, when comparing this problem with the one caused by foreigners buying securities in the LSE, Platt states that "British holdings on foreign exchanges fell far short of foreign holdings in London, and it is convenient but unrealistic to claim that they cancelled each other out."

This issue has an intertemporal aspect as well. Besides assuming that only British investors bought securities at the time of issue, my framework does not monitor changes in ownership after issue, if agents located inside Britain execute those changes. In this sense, if an American residing in London bought a security from a British citizen, the nominal stock series would not change. Of course, if the security moves from London to New York, a nominal stock decrease is expected, since some shares of the security would be delisted from London. This finding is particularly reassuring with respect to the previous literature on British investments overseas. Previous attempts to calculate the amount of British investments overseas on the eve of the First World War followed three strategies. The first was to calculate the level of investment by making assumptions about the return on investments and using the income account of the current account (Imlah (1958) is an example). The second used the residual of the current account. The third and most influential, known as the Jenks-Simon series, used the "British Capital Created and Called" table from IMM to account for all new issues of capital in the LSE ( (Stone 1999) and (Davis and Huttenback 1986) are recent examples). None of these methods made any 
attempt to calculate valuation effects, which means that there was no differentiation

between flows and stocks. Furthermore, since the Jenks-Simon series focused on

primary issues, it ignored developments in the secondary markets (and hence in the

capital stock of the security), such as defaults, repatriations, sinking funds, reinvested

earnings, redemptions and even the maturity of the issue. ${ }^{30}$ For example, a security

issued in 1876 that matured after twenty years would still be included in the "stock"

of British international investments on the eve of the First World War. ${ }^{31} \mathrm{My}$

procedure accounts for all these changes, since they would affect the nominal stock of

capital of the security.

Summary of assumptions

A summary of the main assumptions presented as well as others implicit in the text is presented below:

\footnotetext{
${ }^{30}$ A sinking fund is a dedicated fund created by a company or government in order to buy back a certain security. There are several types of rules, including draws and auctions that could occur at market price (if the security was trading below par, for example) or at par. In some cases, a sinking fund is a mechanism for gradual amortization of the principal of a loan, avoiding a one-off large payment at the maturity of the instrument. The practical consequence is that the outstanding stock of a security decreases smoothly over time and this means a lower duration and higher price quotations.

${ }^{31}$ Another problem related to counting only new issues is the practice of underwriting, which was common in the years leading up to the First World War. A financial house, the underwriter, promised to take back the unsold part of the issue of a loan (subscription) in return for a commission. The unsold part of the loan varied and sometimes reached almost $100 \%$ of the issue. The underwriters who took back unsold securities could hold them until markets improved or sell at a deeper discount to investors (who sometimes behaved strategically by negotiating a lower price directly with the underwriter instead of buying the initial subscription). The direct consequence of not taking into consideration the underwriting of securities is that the stocks of assets and liabilities may be overestimated. The subsequent action of the underwriter in cases when it takes back a large percentage of the subscription matters. For a foreign asset, if a British underwriter keeps the securities or sells them later to British agents, it can still be considered British investment overseas. On the other hand, if the underwriter sells the securities to foreign agents the stock of British investment overseas would be overstated if the whole issue was counted. A modern indicator that addresses the issue of underwriting is "free-float capitalization", which excludes from the outstanding capital locked-in shares such as those owned by promoters, company managers and even governments.
} 
- The British external position is measured exclusively by portfolio investments. $^{32}$

- British investors' holdings for each security are given by a proportion of the

\author{
total capital listed for that security at the LSE. ${ }^{33,34}$ In order to make an
}

\begin{abstract}
${ }^{32}$ Chapter 5 contains a discussion about direct investment. In future work, I will provide estimates of British direct investment in order to construct a more accurate measure of British external assets. The task of finding market prices for direct investment is notoriously difficult. Lane and Milesi-Ferretti (2001), Lane and Milesi-Ferretti (2007) and CTW (2013) opt to use cumulated flows corrected for inflation (replacement cost) or exchange rate variation (book value). As already hinted above, for the majority of countries (with the exception of some industrial economies that publish international investment position statistics), the only viable alternative for measuring market prices of direct investment is to use stock market price indices, since the literature is based on aggregated figures coming from external accounts. A compendium of the reasons given in this literature for the inappropriateness of using stock market indexes follows: 1- It is highly doubtful that broad stock market indexes can approximate the returns of privately held corporations. 2 - The use of local stock market returns of tax havens, where much of US Direct Investment Abroad affiliates are located, is not appropriate. 3 - FDI liabilities in the form of greenfield investments bear little relation to the activities represented on the domestic stock market. 4- Some proportion of FDI is attributable to investment in residential and commercial properties. 5- The value of accumulated cash and liquid assets held by an affiliate (Treasury holdings included in FDI) will not have a direct relationship with the stock market. 6 - Breakdowns of FDI between reinvested earnings and new direct investment flows are usually not available. Since prices for direct investment are usually not available even in the twentieth century, our future estimates on stocks of direct investment for the nineteenth century will be comparable to the figures of the twentieth century. The final class of investment present in the international investment position is other investments. There is evidence of large financial houses conceding loans related to sovereign debt restructuring and to trade credit. Estimates of these positions will also be provided in future versions.
\end{abstract}

${ }^{33}$ When a given security exhibited time variation for total capital (either because of expansion of capital or buyback), I assume that those operations were carried out using the market price. This leaves two important possible problems for the measurement of capital. The first concerns securities that were not fully paid at the time of issue. A company could issue a bond or a stock at a certain price but only demand that the investor pay upfront a percentage of the total price (for example 50\%). At any time in the future, the shareholders could be called to pay the difference. It was an incipient mechanism of contingent capital. The upfront percentage was called "paid" or "par" value. Without accurate information on paid value, the amount of capital is overestimated by counting the full value of capital when just a fraction was actually paid. Nonetheless, cases when the company did not call the full amount of capital within a few months after issuance were rare. The other problem is the existence of sinking funds (see footnote 30). Since there were several types of rules, including draws and auctions that could occur at market price (if the security traded below par for example) or at par, some securities may be taken off from the total capital not at the current market price but at face value. I will undertake a careful study of the paid values and sinking funds rules in the future in order to improve the quality of the estimate.

${ }^{34}$ For some US railway securities, the IMM lists the total value traded in UK and the US, instead of the value traded only in the UK. A comparison with Burdett's Stock Exchange Intelligence for the year of 1881 revealed that within a group of 48 American railway securities, 13 suffered from this problem (the total number of American railways securities was 123, but there was not enough information to check the remaining 83). Curiously, these 13 securities were all bonds. Grossman (2002), referring 
allowance for foreign agents buying foreign securities at the LSE, I assume that British held only $80 \%$ of the nominal capital stock of foreign railroad securities and $60 \%$ of the nominal capital stock of foreign sovereign securities traded on the LSE. In the same vein, in order to make an allowance for foreign agents buying British securities at the LSE, I assume that only $80 \%$ of the nominal capital stock of British securities traded on the LSE was held by British. Those assumptions are on the extreme side of existing estimates in both cases. By overestimating the share of foreign agents in possession of British and foreign assets traded at the LSE, I likely understate the UK net external assets position (and the net revenues coming from it). ${ }^{35}$

- When coupon payments were not available for the calculation of yields, they were substituted for coupon rates. The use of coupon rates could overestimate yields when coupons were not paid, a rather frequent event. The substitution is also not applicable to dividend payments of equity securities, which do not contain coupon rates.

The next chapter applies the procedure described above and reveals the main empirical findings of this work.

only to equity, affirms that the same reporting problem exists for some French railways. This issue overstates British external asset position, since a proportion of the whole capital stock of the firm would be attributed to British investors, instead of a proportion of the exact amount effectively trading at the LSE.

${ }^{35}$ These assumptions will be refined in future versions of this paper that include the full sample of securities traded in the London Stock Exchange, with different weights for more granular classes of asset and in line with the evidence of the section Limitations. 


\section{Chapter 3: Main Results}

The data sample contains securities from four sectors: foreign and British railroad securities and foreign and British sovereign securities. ${ }^{36}$ In total, 601,869 observations are available for total capital and 571,402 for prices. Those observations correspond to 3,680 securities traded between January 1869 and July 1914, of which 42 are British sovereign/government bonds, 1,202 are British railroads and 875 foreign sovereign bonds. Government/sovereign securities were the main class of assets traded at the LSE and British government securities were the safe asset of the period. ${ }^{37}$ Railroads were the most important sector of private investment for the period. The US was the major destination for British foreign investments in railroads, but the sample includes countries from all continents, including Canada, Argentina, India, the Ottoman Empire and Brazil. Foreign sovereign securities and foreign railroad securities represented $68 \%$ of the total number of foreign securities traded at the LSE (Stone 1999). According to the Stock Exchange Official Intelligence for 1902 (page 1898), the total capital of sovereign/government and railroad securities amounted to $88 \%$ of the total capital of all securities traded at the LSE.

\footnotetext{
${ }^{36}$ British securities are those from England, Scotland and all of Ireland (Wales is part of England).

${ }^{37}$ Besides Exchequer bonds and bills, consols and war loans, the securities classified as government include debt from the Red Sea Telegraph Company, the Metropolitan Police and equity from the Bank of England and the Bank of Ireland. The last two securities were almost bonds, since they had fixed yields. Also originally included were sovereign bonds from other countries, such as Turkey and Transvaal that carried official guarantees from the British government. I opted to assign those last bonds to the countries that originally issued the securities for the sake of keeping a pure geographic breakdown of securities. Of course, when considered under the principle of ultimate borrower, those securities would be British liabilities. See chapter 5 for more details.
} 
Table 4 summarizes the main characteristics of the data. ${ }^{38}$ In terms of total capital, foreign companies have a higher mean and standard deviation (due to sovereign securities - governments were able to issue more liabilities than private companies were). Average closing prices were higher than average issuance prices and face values (normalized to 100) for British securities, but below issuance prices and face values for foreign securities. The average coupon rate (contained in the name of the security) is $4.45 \%$ in the case of British securities and $4.90 \%$ in the case of foreign securities, with a larger standard deviation and a lower maximum value for foreign securities. Six dummy variables were created: Equity, Equity Preferred, Dollar Denominated, Pound Denominated, Sterling Clause and Gold Clause. On average, $30 \%$ of the securities are equity (which means that $70 \%$ are debt), and $14 \%$ are preferred shares (meaning that common stock is $47 \%$ of total equity). In the case of Britain, $50 \%$ of securities are equity and $28 \%$ of securities are preferred stock, while for the rest of the world these shares are $18 \%$ and $6 \%$. These figures refer only to the number of securities and not capital values. While all British securities are quoted in pounds, $23 \%$ of foreign securities are quoted in dollars, but almost $14 \%$ of the total or $61 \%$ of those quoted in dollars contain a sterling or gold clause, which guarantees the payment in pounds or gold (abolishing exchange rate risk).

\footnotetext{
${ }^{38}$ The table's figures are in the original currency of the data. For example, "Capital Amount of Share" refers to the indivisible face value of one share or the capital amount divided by the number of shares. In the case of British securities, the maximum value of 200 represents 200 pounds, but in the case of foreign securities, the maximum value of 1000 possibly represents 1000 dollars, which is equivalent to 200 pounds.
} 


\begin{tabular}{|c|c|c|c|c|c|}
\hline Variable & $\mathrm{N}$ & Mean & SD & Min & $\operatorname{Max}$ \\
\hline \multicolumn{6}{|c|}{ All securities } \\
\hline Capital (Pounds) & 601869 & $5.33 E+06$ & $2.80 E+07$ & 0 & $8.89 E+08$ \\
\hline Capital Amount of Share & 194994 & 302.69 & 406.96 & 0 & 1000 \\
\hline Par & 595999 & 98.37 & 51.59 & 0 & 1000 \\
\hline Prices Closing & 571452 & 89.43 & 42.41 & 0 & 1165 \\
\hline Prices Last Business & 245025 & 89.42 & 48.44 & 0 & 1331 \\
\hline Price Issuance & 101735 & 88.77 & 28.79 & 1 & 1922 \\
\hline Coupon Rate & 493781 & 4.75 & 1.19 & 0.5 & 12.86 \\
\hline Equity (Dummy) & 605157 & 0.3 & 0.46 & 0 & 1 \\
\hline Equity Pref. (Dummy) & 605157 & 0.14 & 0.35 & 0 & 1 \\
\hline Exchange Rate & 605157 & 4.98 & 0.3 & 4.83 & 6.48 \\
\hline Dollar denominated (Dummy) & 605157 & 0.85 & 0.35 & 0 & 1 \\
\hline Pound denominated (Dummy) & 605157 & 0.15 & 0.35 & 0 & 1 \\
\hline Sterling Clause & 605157 & 03 & 0.17 & 0 & 1 \\
\hline Gold clause & 605157 & 0.06 & 0.23 & 0 & 1 \\
\hline \multicolumn{6}{|c|}{ British securities } \\
\hline Capital (Pounds) & 220282 & $3.89 E+06$ & $2.57 E+07$ & 2125 & $5.92 E+08$ \\
\hline Capital Amount of Share & 28086 & 31.34 & 32.35 & 0 & 200 \\
\hline Par & 220290 & 90.7 & 26.37 & 0 & 205.5 \\
\hline Prices Closing & 210066 & 102.38 & 47.04 & 0 & 1165 \\
\hline Prices Last Business & 129440 & 103.53 & 48.35 & 0 & 1331 \\
\hline Price Issuance & 3852 & 80.67 & 29.1 & 5 & 150 \\
\hline Coupon Rate & 166560 & 4.45 & 1.05 & 0.5 & 12.86 \\
\hline Equity (Dummy) & 221870 & 0.5 & 0.5 & 0 & 1 \\
\hline Equity Pref. (Dummy) & 221870 & 0.28 & 0.45 & 0 & 1 \\
\hline Exchange Rate & 221870 & 5.04 & 0.36 & 4.83 & 6.48 \\
\hline Pound denominated (Dummy) & 221870 & 1 & 0 & 1 & 1 \\
\hline Other denominated (Dummy) & 221870 & 0 & 0 & 0 & 0 \\
\hline \multicolumn{6}{|c|}{ Rest of the World securities } \\
\hline Capital (Pounds) & 381587 & $6.17 E+06$ & $2.93 E+07$ & 0 & $8.89 E+08$ \\
\hline Capital Amount of Share & 166908 & 348.35 & 422.89 & 1 & 1000 \\
\hline Par & 375709 & 102.87 & 61.32 & 0 & 1000 \\
\hline Prices Closing & 361386 & 81.91 & 37.47 & 0 & 370 \\
\hline Prices Last Business & 115585 & 73.63 & 43.4 & 0 & 452 \\
\hline Price Issuance & 97883 & 89.09 & 28.74 & 1 & 1922 \\
\hline Coupon Rate & 327221 & 4.9 & 1.23 & 1 & 10.5 \\
\hline Equity (Dummy) & 383287 & 0.18 & 0.38 & 0 & 1 \\
\hline Equity Pref. (Dummy) & 383287 & 0.06 & 0.24 & 0 & 1 \\
\hline Exchange Rate & 383287 & 4.95 & 0.26 & 4.83 & 6.48 \\
\hline Pound denominated (Dummy) & 383287 & 0.77 & 0.42 & 0 & 1 \\
\hline Other denominated (Dummy) & 383287 & 0.23 & 0.42 & 0 & 1 \\
\hline Sterling Clause & 383287 & 0.05 & 0.22 & 0 & 1 \\
\hline Gold clause & 383287 & 0.09 & 0.28 & 0 & 1 \\
\hline
\end{tabular}

Table 4: Summary statistics 
Figure 2 maps the average shares of British capital invested in each country for the period 1869-1914 (total amount of British capital invested in the country for the period 1869-1914 over the total global amount of British capital invested offshore for the same period). The upper panel contains data for sovereign securities; the middle panel is dedicated to railroad securities and the lower panel to the total sum of the two sectors. The two sectors are distinct in terms of distribution of capital: while holdings of railroad securities were heavily concentrated in the US (with over 55\% of the British investment in railroads), holdings of foreign sovereign securities were more equally distributed among several countries, led by Russia and France. The US only received between $1 \%$ and $5 \%$ of the British capital invested in sovereign securities. France, Argentina, Canada and India followed the US (with much smaller shares) as the most popular destinations for British investment in railroads. Combining railroad and sovereign securities, the most popular destinations overall for British capital were the US and France, followed by Russia and Spain.

Figure 3 follows the same structure of Figure 2 and maps the growth of the stock of British investment by country between two periods: 1869-1875 and 19051914. ${ }^{39}$ The middle panel shows that British capital investment in railroads fell over time in Asia and Europe in general and increased in the Americas, especially in Argentina, with growth over 100\%, and also in Mexico, Colombia and the US. With respect to sovereign bonds, British investment grew by more than $100 \%$ in South

\footnotetext{
${ }^{39}$ The growth rate is defined as the average of the British total capital received for each country and class of investment (sovereign/ railroad) over the period 1905-1914 divided by the average over the period 1869-1875. I chose this procedure instead of simply calculating the growth from the year 1869 to the year of 1914 because many countries did not receive any investment in the year 1869 and they would drop out of the calculation.
} 
Africa and Japan (including the Korean peninsula), followed by Germany. The stock of British capital in sovereign securities fell in Spain, the Ottoman Empire, the US and several Latin American countries between the two periods.

The heterogeneous distribution of resources and growth indicates that "pull" factors were important in explaining why British investors sent money abroad. In the case of railroads, the rapid expansion of the American rail network and companies during that period explains the position of the US as the top destination for British capital. By the end of the period, the expansion of American railways slowed, since tracks already covered most of the territory. On the eve of the First World War, British investors were allocating new investments to the expansion of railroads in Argentina in order to improve the transportation of agricultural and livestock exports. The growth of the stock of capital in German and Japanese sovereign bonds might be a result of the state-led industrialization processes occurring in those countries. Two factors might explain the growth of the British capital stock in South Africa: state investment in gold mines discovered around this period and investment related to the incorporation of the two Boer republics as colonies after the Boer Wars (it is also possible that the costs of the war were partly financed by bonds issued by the British colony in South Africa, which absorbed the Boer republics after the war). 

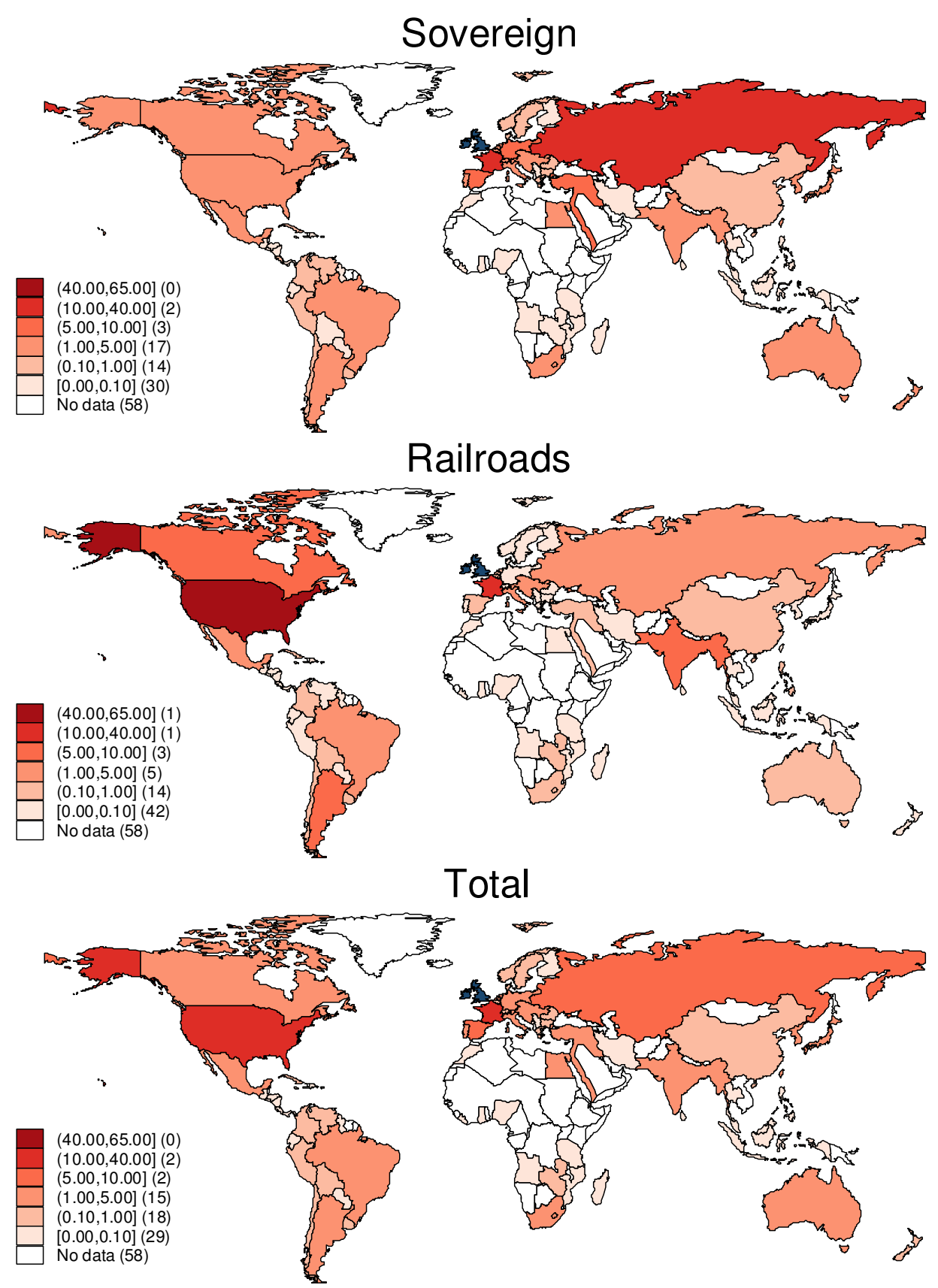

Figure 2: Average Distribution of British Investment for the period 1869-1914 (total amount of British capital invested in the country for the period 1869-1914 over the total global amount of British capital invested offshore for the same period). 

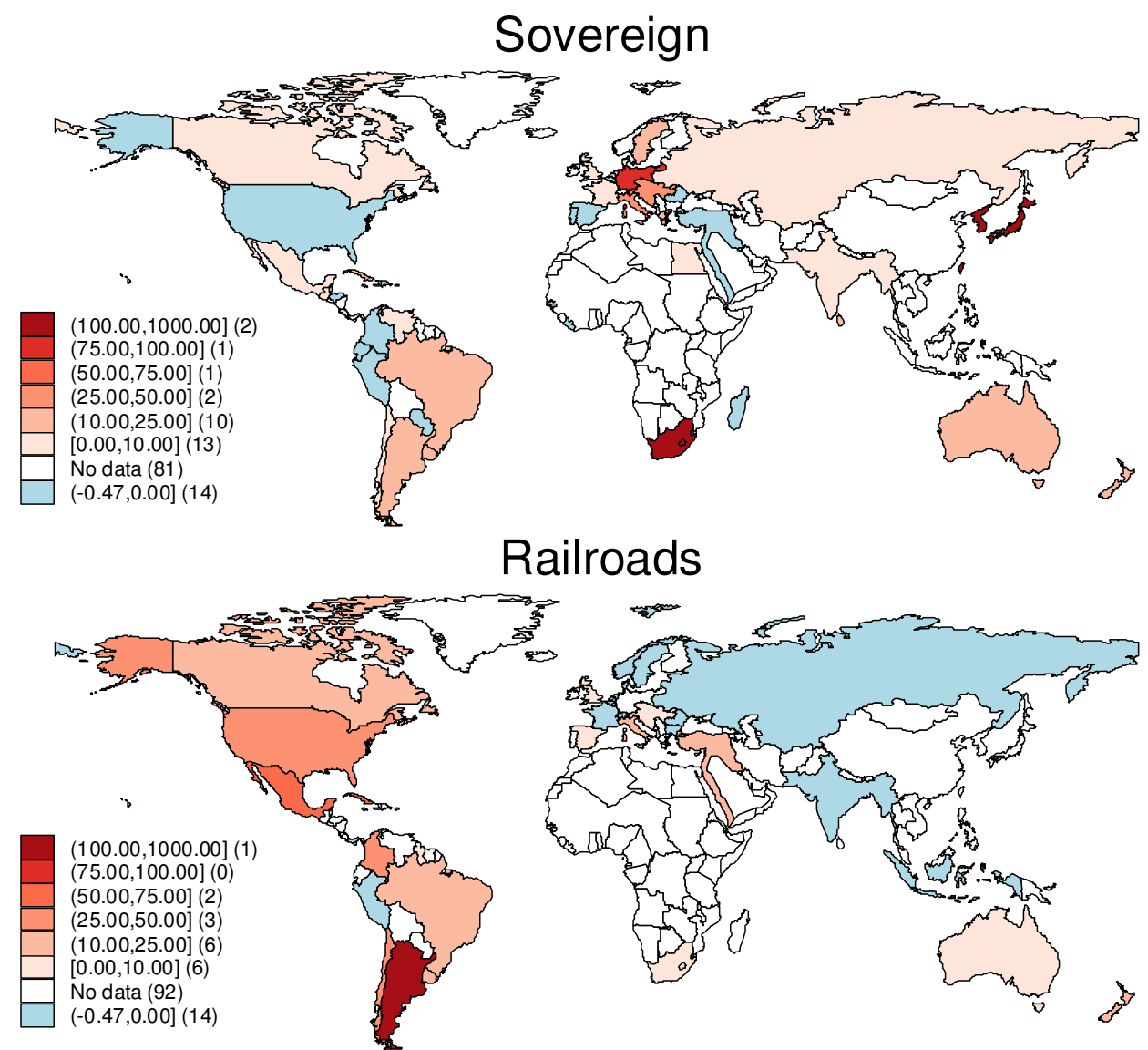

\section{Total}

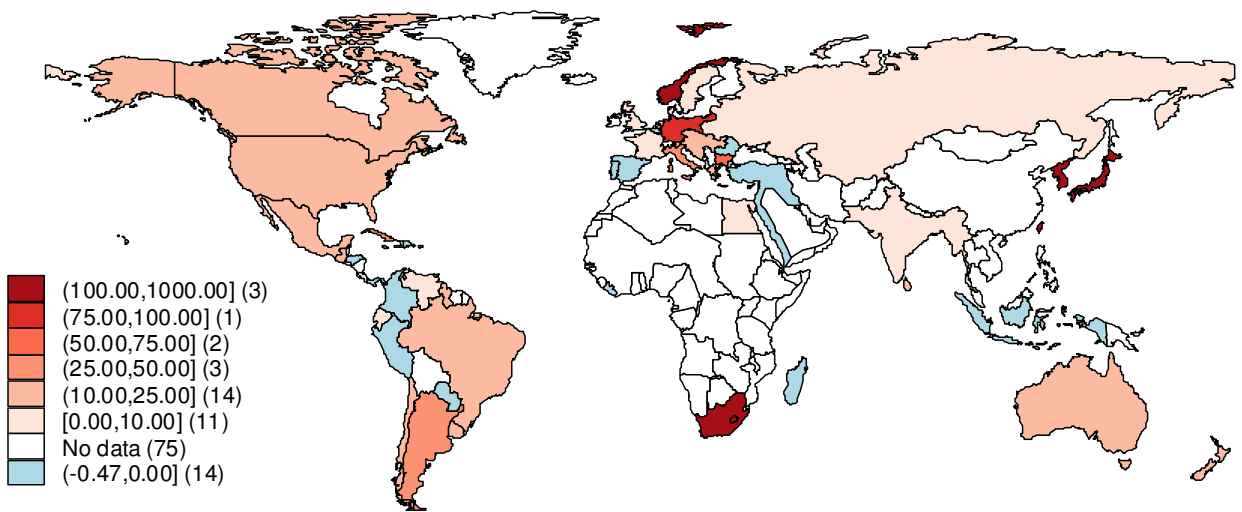

Figure 3: Growth of the stock of British Investments between 1869-75 and 1905-14 (percent). 


\section{British International Investment Position}

For each class of investment (sovereign / railroad) and geographical location (UK / foreign), I compute two series:

1) Issuance price series: the sum of the capital value of each outstanding security for each month, measured at issuance prices.

2) Market prices series: the sum of the capital value of each outstanding security for each month, measured at current market prices.

Foreign securities compose UK's external assets while British securities compose UK's external liabilities. The cumulative capital gains on UK external assets and liabilities are given by the differences between the market price series and the issuance price series. ${ }^{40}$ Market prices indicate the valuation of securities bought by a British investor at a specific moment in time. If an investor decided to sell that security at that moment in the market, he would receive a value that is different from the price at which he acquired the asset, which is the capital gain. Comparing market prices and issuance prices is analogous to a comparison of series constructed from cumulated current account balances (without valuation effects in the language of Gourinchas and Rey (2007)) and net external positions (calculated taking into account valuation effects). In this case, however, both estimates come from the same data

\footnotetext{
${ }^{40}$ Dollar denominated securities (mostly from the US, Canada and some Latin America countries) were converted at the official exchange rate. From 1878 to 1914, I used the official exchange rate of 4.86, based on the evidence in Figure 1. Before that, in the greenback period, the exchange rate was as high as 6.48 in 1869 . Note that for most of the period, it was common practice in the London financial market to use the round value 4 shillings per dollar, which translates into 5 dollars per pound sterling. For the other currencies, I used the following exchange rates corresponding to one British pound sterling: 20.43 German marks, 26.28 Italian liras, 6.28 Russian rubles, 24.02 Austrian-Hungarian kroners, 12.10 Dutch guilders, 25.2 Spanish pesetas, 9.72 Japanese yens, 25.2 Belgian francs and 18.10 Danish kroners.
} 
source. Figure 4 shows the issuance and market price series for foreign railroad and government securities (panel A), and for British railroad and government securities (panel B). The value of outstanding foreign railroad securities rises almost continuously from 1869 to 1914 in both series (issuance price and market price). Cumulative capital gains (the difference between the two series) are negative before 1880 and positive between 1880 and 1900. Market value increases after 1900, meaning that capital gains are higher for the last years of the sample. For UK railroad securities, the market price series is above the issuance price series for the entire period before 1907. Cumulative capital gains increase almost continuously from 1869 until around 1895 and decline thereafter, turning negative from 1907 to 1914. The value of outstanding foreign government bonds grows at a slower rate than foreign railroad securities, but the level of the former is higher than the level of the latter. ${ }^{41}$ Cumulative capital gains are roughly stable for foreign sovereign securities after 1885. UK government securities' cumulative capital gains are smaller than for foreign sovereign bonds. They are mildly positive for a short period from 1895 to around 1900 and then turn negative after 1900. The value of outstanding foreign securities is much higher than the value of outstanding British securities in both classes (railroads/sovereign).

\footnotetext{
${ }^{41}$ The four "tumbles" in the series are probably due to misclassifications of the exchange rate of some securities. Future versions of this work will fix the problem. The calculation of capital gains is not affected.
} 

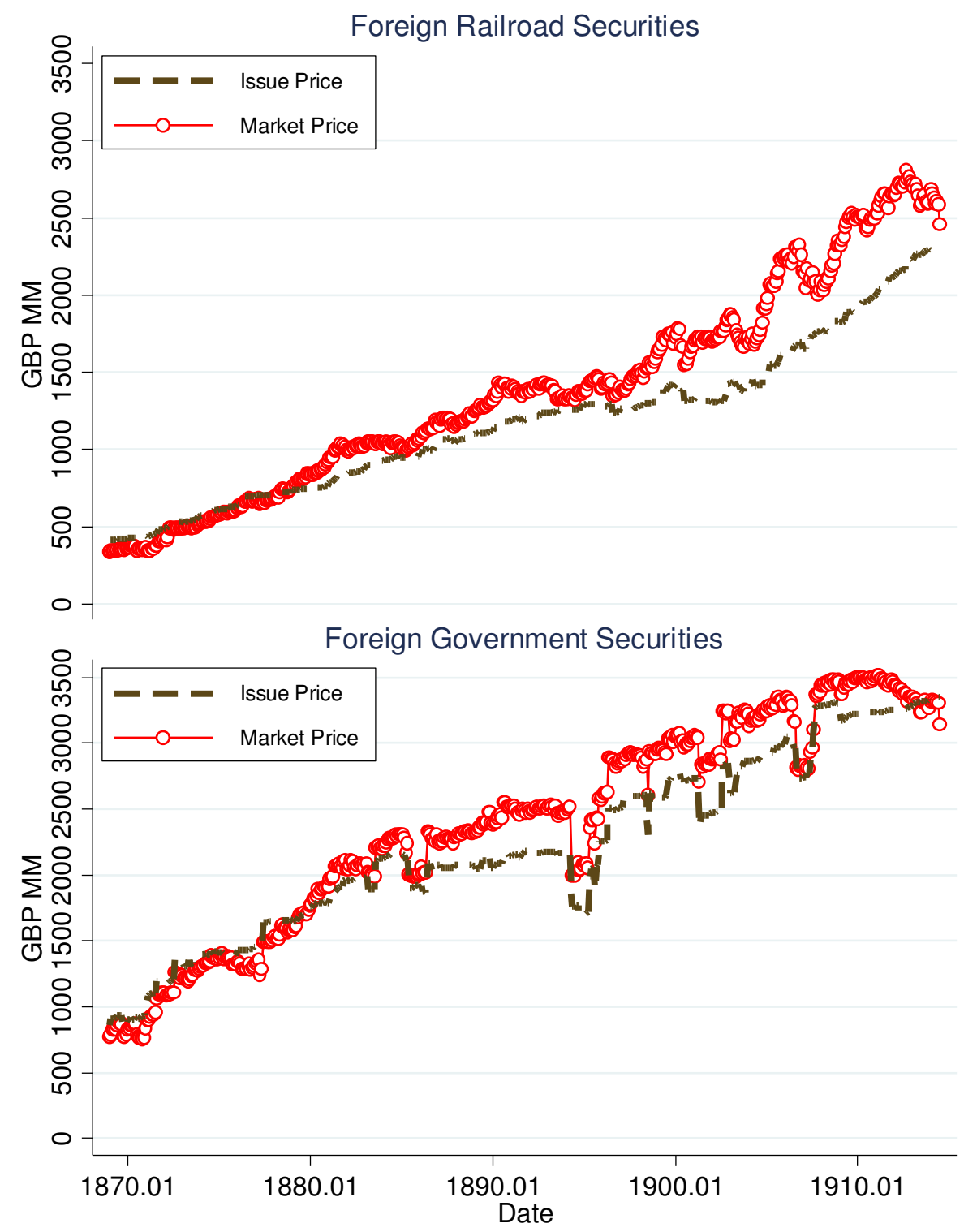

Figure 4 Panel A: Value of outstanding foreign railroad and government securities (Millions of pounds sterling). Issue or issuance price series is the sum of the capital value of each outstanding security for each month, measured at issuance prices. Market prices series is the sum of the capital value of each outstanding security for each month, measured at current market prices. 


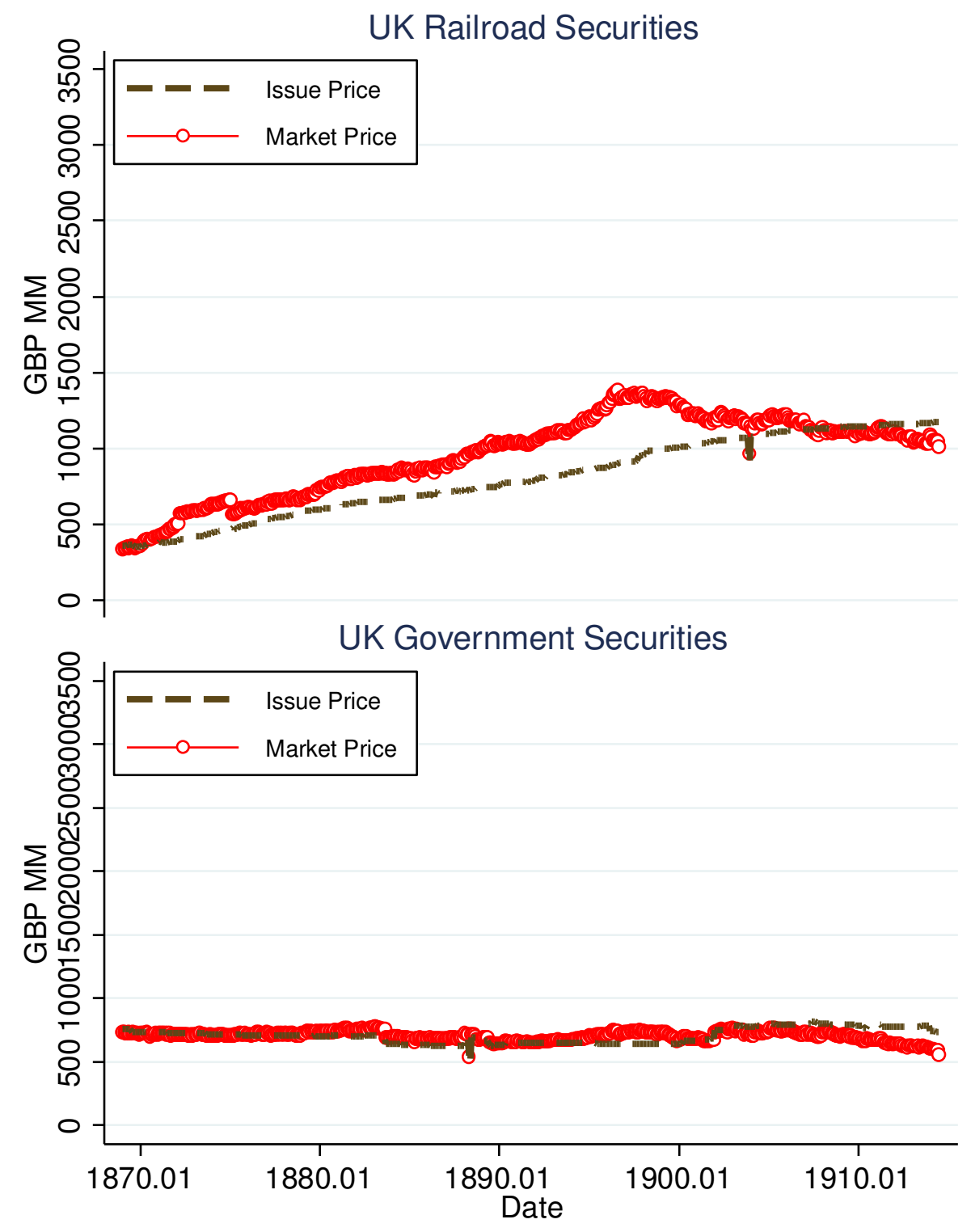

Figure 4 Panel B: Value of outstanding British railroad and government securities (Millions of pounds sterling). Issue or issuance price series is the sum of the capital value of each outstanding security for each month, measured at issuance prices. Market prices series is the sum of the capital value of each outstanding security for each month, measured at current market prices.

Figure 5 (panels A and B) scales the series presented in Figure 4 (panels A and B) by UK's nominal GDP. Figure 5 assumes that British investors owned $80 \%$ of 
the outstanding value of foreign railroad securities traded at the LSE, $80 \%$ of the outstanding value of British railroad and government securities traded at the LSE (so that foreign investors owned $20 \%$ of British securities) and $60 \%$ of foreign government securities. ${ }^{42}$ The sum of the market price series for foreign government and railroad securities is a proxy for the total British external asset position while the sum of the market price series for British government and railroad securities is a proxy for the total British external liability position. The difference between the former and the latter constitutes a proxy for the British net external position. To my knowledge, this is the first monthly time series estimate of the British external position that takes into account capital gains and follows the modern methodology for the compilation of international investment positions. ${ }^{43}$

The issuance price series for foreign railway holdings (already multiplied by 0.8) oscillates between $60 \%$ and $80 \%$ of GDP from 1885 to 1914 , after increasing from $35 \%$ to $60 \%$ of GDP between 1869 and 1885 . The market price series has three distinct periods. In the first, between 1869 and 1885, it increases from 30\% of GDP to $80 \%$ of GDP, eventually overtaking the issuance price series in 1880 . It then stabilizes at around 80\% of GDP until 1905, when it moves to another level around

\footnotetext{
42 The nominal GDP series is taken from Dimsdale, Hills and Thomas (2015). The series includes the GDP for the whole island of Ireland. The formula for the top panel of figure 5 panel A is $0.8 *$ (Issuance or Market Prices Series of Foreign Railroad Securities)/GDP, for the bottom panel of figure 5 panel $\mathrm{A}$ is 0.6 * (Issuance or Market Price Series of Foreign Government Securities)/GDPand for the two panels of figure 5 panel $\mathrm{B}$ is

$0.2 *$

(Issuance or Market Price Series of British Railroads or Government Securities)/GDP.

${ }^{43}$ Previous estimates are in the range of $120 \%-160 \%$ of GDP for total assets before First World War. Using the issuance prices (since the previous estimates did not take in consideration capital gains), I obtain a value around $160 \%$. Multiplying $160 \%$ by 1.1 (since the sample represents around $90 \%$ of the total value of securities traded at the LSE), I obtain approximately $180 \%$. Curiously, this figure does not change by much when taking in account capital gains for the specific year of 1914 .
} 
$100 \%$ of GDP. The sudden drop in July 1914 probably reflects the events that led to the First World War.

The issuance and market price series for foreign government securities holdings rise from around 50\% of GDP in 1869 to around 110\% of GDP in 1885. Both series are stable from 1885 to 1914, with the issuance price series around 90\% of GDP and the market price series around $110 \%$ of GDP. When scaled by the ratio of ownership of British assets, the capital gains on liabilities coming from UK railway securities in the years 1869-1910 are lower than the capital gains on foreign assets for most years. Capital gains on UK government securities are very low when compared to those of UK and foreign railroad securities. 


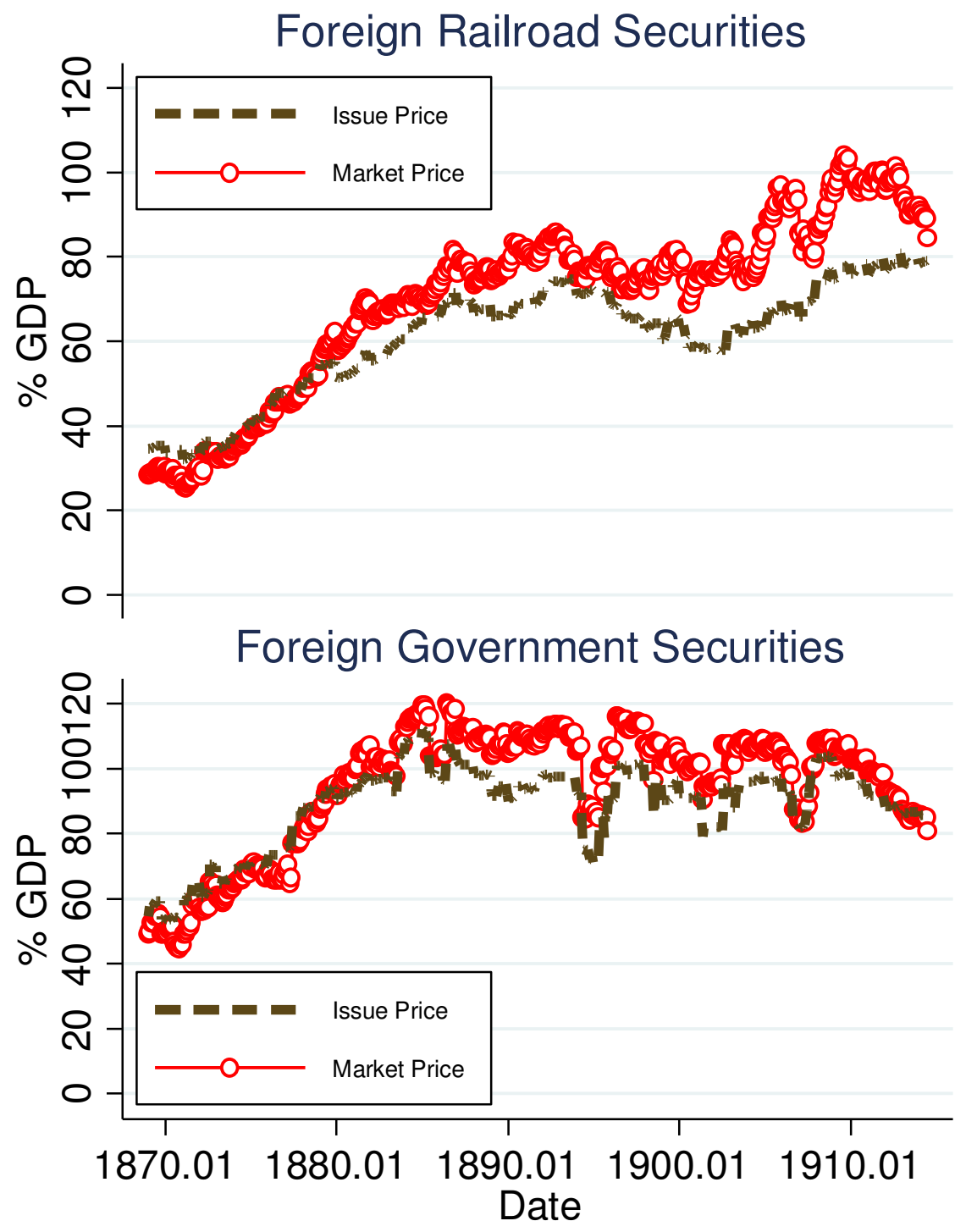

Figure 5 Panel A: Measures of UK external assets (expressed as percentage of GDP and scaled by 80 percent for railroads and 60 percent for government securities). The formula for the top panel is $0.8 *$ (Issuance or Market Prices Series of Foreign Railroad Securities)/GDP For the bottom panel is 0.6*(Issuance or Market Price Series of Foreign Government Securities)/GDP. 


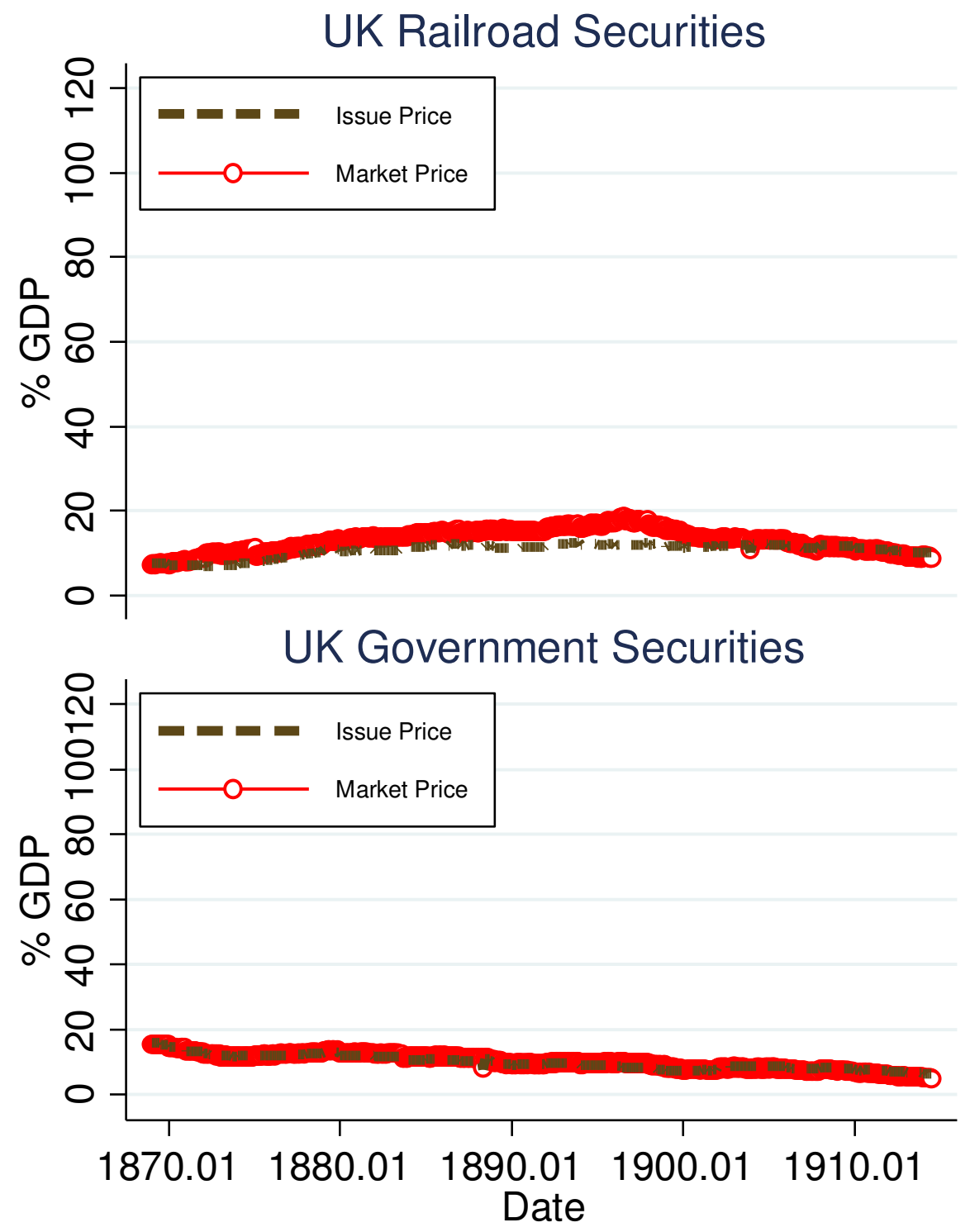

Figure 5 Panel B: Measures of UK external liabilities (expressed as percentage of GDP and scaled by 20 percent). The formula for the two panels is $0.2 *$ (Issuance or Market Price Series of British Railroads or Government Securities)/GDP.

\section{Dividend yield estimates}

Dividend yields and coupon rates $(i)$ are the other necessary component for measurement of exorbitant privilege. The IMM contains specific columns for 
dividend yields. ${ }^{44}$ I developed a specific procedure to organize the data for railroad securities (described in chapter 5). The estimates for coupon payments on government securities use the coupon rates collected in the names of the securities.

Figure 6 presents the series for dividend and interest income derived from the information on dividend yields and coupon rates of the database. ${ }^{45}$ The figure also presents yearly estimates from the income account of the current account from the existing literature (Mitchell 1988). Since dividend and interest incomes on external assets and liabilities are the source of the revenues represented by the income account, the comparison between the two sets of series is direct. The series "Income Assets New" represents the dividend and interest income from foreign railroad and government securities while the series "Income Liabilities New" represents the dividend and interest income from British railroad and government securities. The levels of both series are close to the ones from the literature, with minor deviations. While the increase in dividends / interest income from 1905 to 1914 is more accentuated in the new asset series (probably due to the growth of the stock of foreign railroad securities), both asset series (from this paper and from Mitchell) oscillate around 6-7\% of GDP annually from 1880 to 1905 . The new liabilities series is above the corresponding series from the literature for most of the period. The new liabilities series actually declines a bit over time while the series from Mitchell rises a bit. Since

\footnotetext{
${ }^{44}$ The IMM and the financial market of the period 1869-1914 do not differentiate between equity and debt securities. Coupon payments of debt securities were also called dividend payments. I usually use the modern terminology.

${ }^{45}$ For each security and each month, the coupon rate and the dividend yields were multiplied by the outstanding value of the capital of the security. The result is the dividend / interest income in pounds sterling. This income was multiplied by the factors of $0.6,0.8$ and 0.2 respectively for foreign government securities, foreign railroad securities and British securities. After aggregation into two series for foreign securities and British securities, they were divided by GDP.
} 
the British external liabilities position was small in comparison to the external assets position, the liabilities yields are also small in comparison to asset yields.

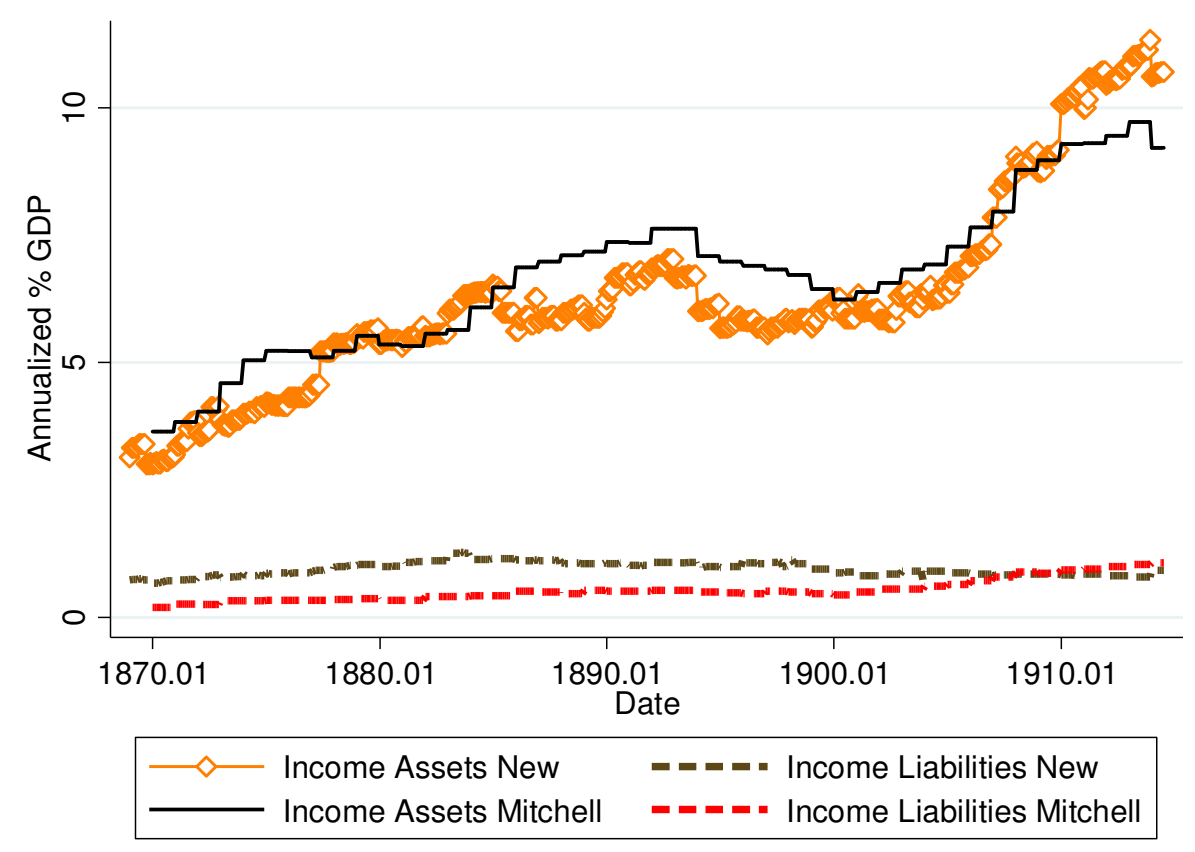

Figure 6: Dividend and coupon income on external assets and liabilities (percentage of GDP). Series "New" are calculated by multiplying the coupon rate and the dividend yields by the outstanding value of the capital of each security and aggregating (taking into account the percentages of 80/60/20). "Mitchell" refers to the estimates of the income account of the current account from Mitchell (1988).

Figure 7 presents average excess rates of return for the period 1869-1914 by class of investment (railroads/sovereign) and country. ${ }^{46}$ Excess rates of return are obtained by subtracting the rates of return on corresponding British securities from the rates of return on foreign securities, in order to represent accurately the spread

\footnotetext{
${ }^{46}$ Average excess rates of return are the capital gains + dividend yields / coupon rates for securities of a particular country discounted of capital gains + dividend yields / coupon rates for British securities. For example, the average monthly rate of return of Brazilian securities was $0.13 \%-0.25 \%$ higher than the return on British securities.
} 
between assets and liabilities from the viewpoint of a British investor. The maximum rate of return on railroads is higher than the maximum rate of return on sovereign securities, but the lowest rate of return on sovereigns (-0.13\% per month) is higher than the lowest rate of return on railroads $(-0.77 \%$ per month), which means that railroad securities are riskier than sovereign securities. Latin America is the continent with highest rates of return in general. Figure 8 presents the breakdown for railroad securities into common equity, preferred equity and debt (all foreign sovereign securities are debt). 

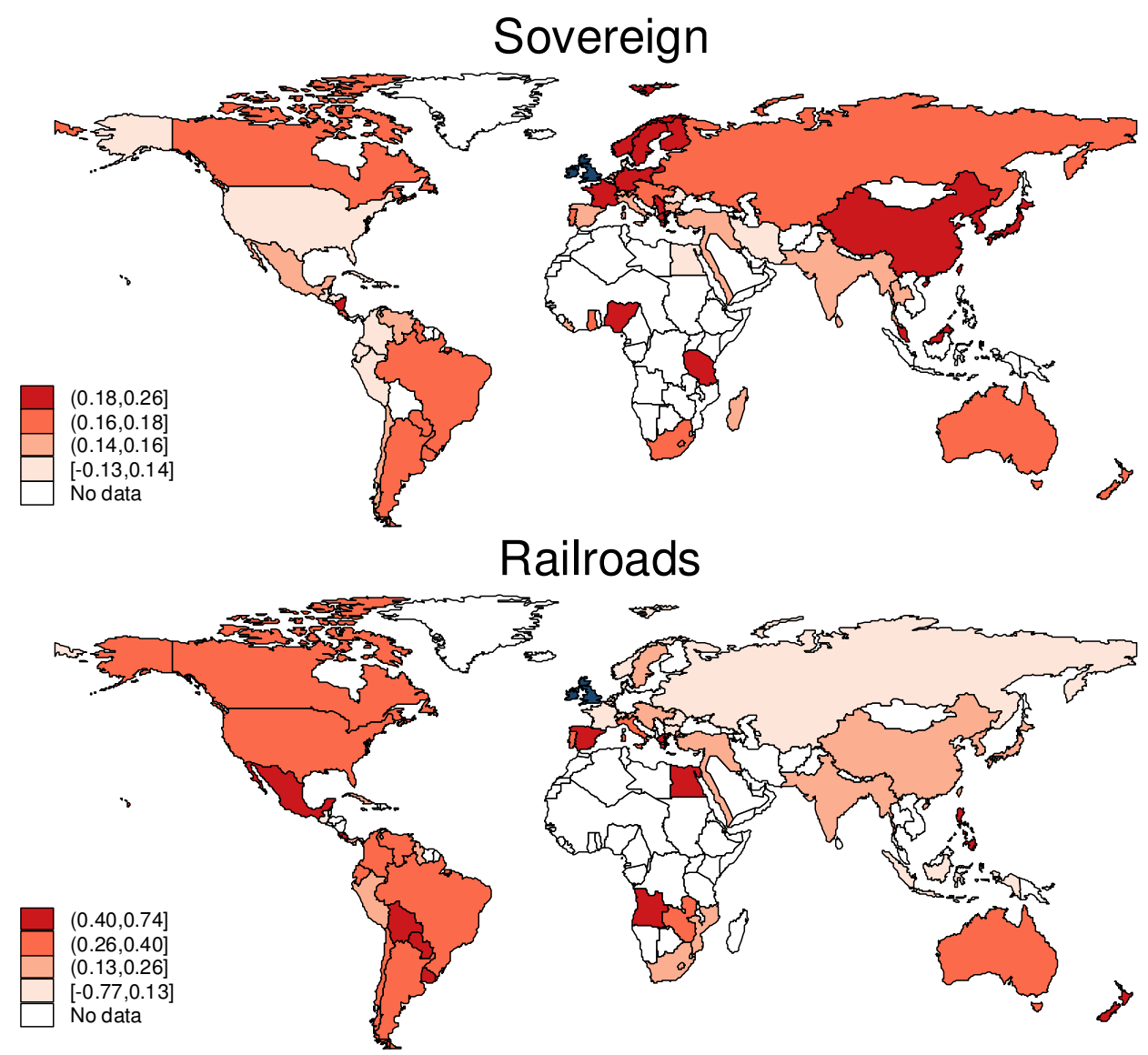

\section{Total}

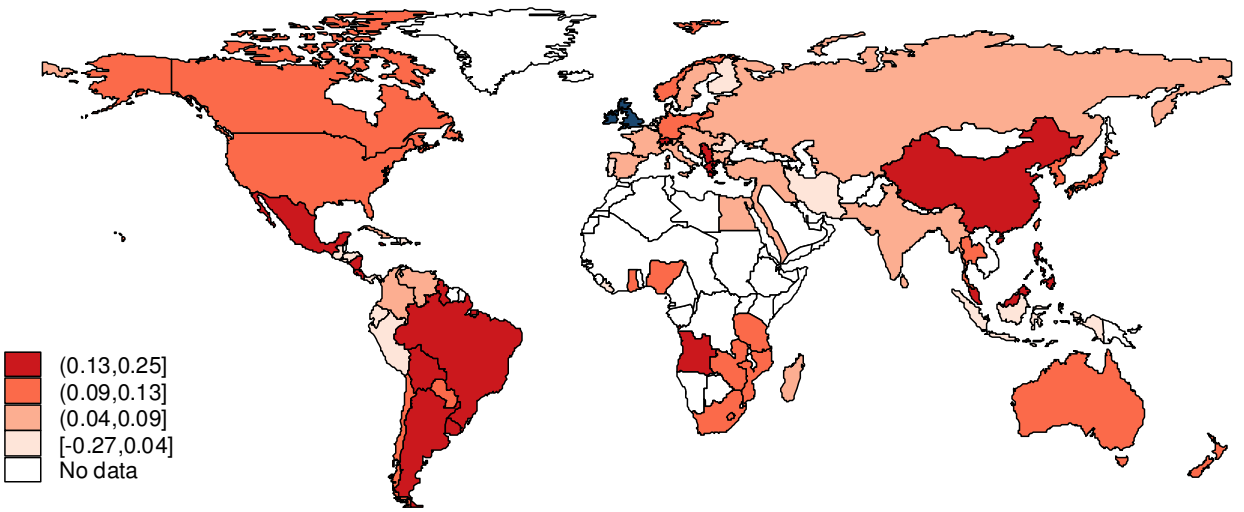

Figure 7: Average monthly excess return for 1869-1914 (percentage). Colors represent capital gains + dividend yields / coupon rates for securities of the country discounted of capital gains + dividend yields / coupon rates for British securities. 


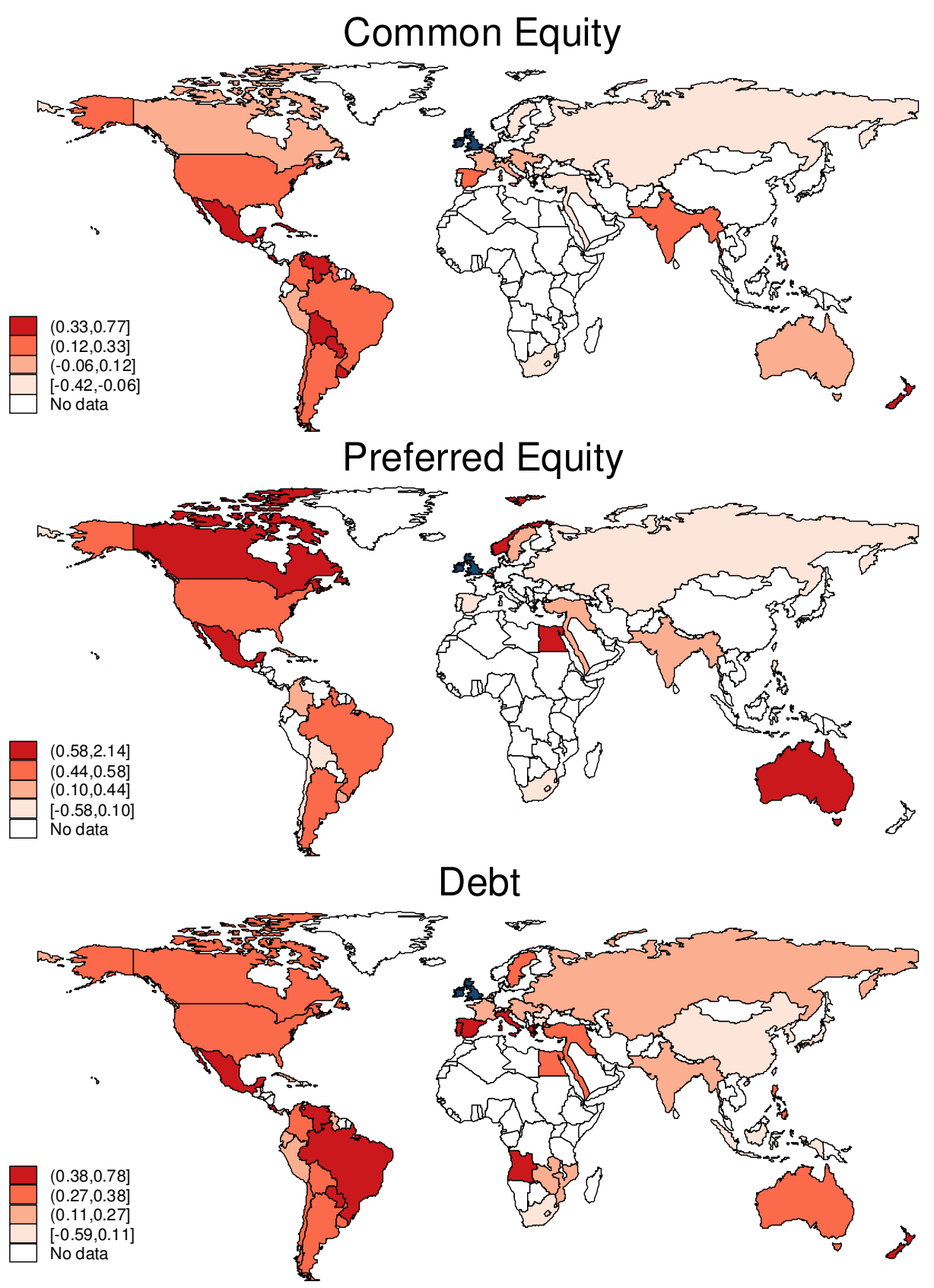

Figure 8: Average monthly railroad securities excess return for 1869-1914 by railroad class of asset (percentage). Colors represent capital gains + dividend yields / coupon rates for railroad securities of the country discounted of capital gains + dividend yields / coupon rates for British railroad securities. 


\section{Aggregate Exorbitant Privilege}

My benchmark measure of net revenues earned by Britain vis-vis the rest of the world (or aggregate exorbitant privilege) is the sum of the excess capital gains and dividend/interest income calculated from the proxies for external liabilities and assets in the previous sections. Capital gains are the sum of the differences between market price series and issuance price series of foreign securities (railroad / sovereign) minus the differences between market price series and issuance price series of British securities (railroad / sovereign) in Figure 5. Dividend and interest income come from Figure 6. Figure 9 presents the results as a percentage of GDP. Since liabilities are scaled by a factor of 0.2 ( $20 \%$ foreign holdings of British securities), most of the dynamics of net revenues comes from the dynamics of capital gains and dividend/interest income from external assets. The growth in net revenues is in tandem with the increase in the net external position of the United Kingdom from 1869 to 1880 . For the first decade of the sample, Britain paid returns to the rest of the world because net capital gains were negative and net dividend/interest income was positive but small in comparison to capital gains. From 1880 to 1914, revenues from capital gains on foreign railroad securities and to a lesser extent from foreign government securities boosted the revenues received by Britain. The series reached peaks of $40 \%$ of GDP in some months but the average is stable at a level just below $20 \%$ of GDP. The average for the whole period (1869-1914) is $13.4 \%$ of GDP, with substantial fluctuations. ${ }^{47}$

\footnotetext{
${ }^{47}$ Table 7 and Table 8 of the appendix show that the ratios of $80 \%$ for British ownership of foreign railroads securities, $60 \%$ of British ownership of foreign sovereign securities, $20 \%$ of foreign ownership of British securities assumed in this paper are not determinant for the result. Table 7 varies the ratio of British ownership of railroads securities from $70 \%$ to $100 \%$ while varying the ratio of
} 


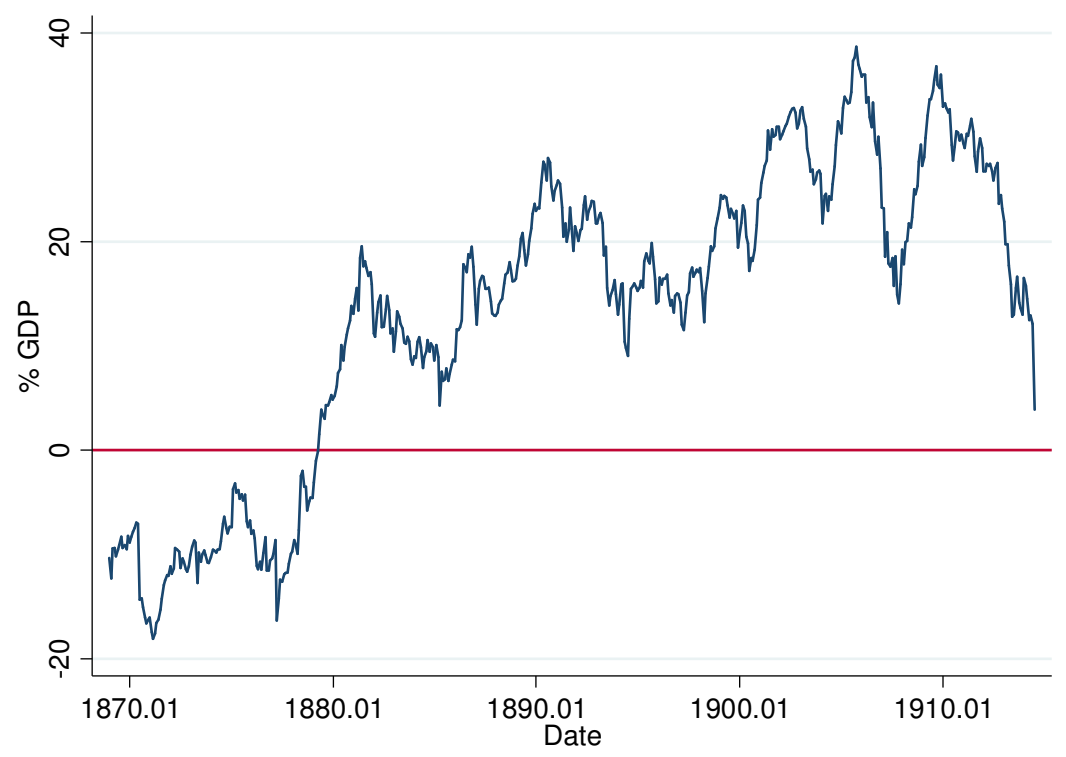

Figure 9: Measure of net revenues earned by Britain vis-a-vis the rest of the world (aggregate exorbitant privilege as a percentage of GDP). Revenues are the sum of excess capital gains (differences between market price series and issuance price series in Figure 5) and dividend and interest income from Figure 6. The two components (from Figure 5 and Figure 6) take into account the percentages of 80/60/20.

What do these figures mean in terms of equation 4 ? Figure 10 presents the answer. The left-hand side of equation 4 represents the capital gains and dividend yields on external assets $\left(k g_{t}^{A}+i_{t}^{A}-\gamma\right)$ while the right-hand side adds the yields and capital gains on external liabilities $\left(k g_{t}^{L}+i_{t}^{L}-\gamma\right)$ scaled by the ratio of liabilities over assets $\left.\left(L_{t-1} / A_{t-1}\right)\right)$. The condition for the existence of exorbitant privilege is fulfilled for almost the whole period, with the exception of the period $1869-1880$.

ownership of British securities by foreigners from $0 \%$ to $30 \%$. In Table 8 , the ratio of ownership of foreign government securities by British varies from $50 \%$ to $80 \%$ while the ratio of ownership of British securities by foreigners varies from $0 \%$ to $30 \%$. In the two tables, using the most adverse conditions to the existence of revenues (high ownership of British securities by foreigners and low ownership of foreign securities by British), the estimates reached a low level of around 11\% of GDP (the highest levels are around $18 \%$ of GDP). 
Since British external liabilities are tiny with comparison to British external assets, the right-hand side of the equation is almost flat (since it is scaled by liabilities over assets) with comparison to the left-hand side.

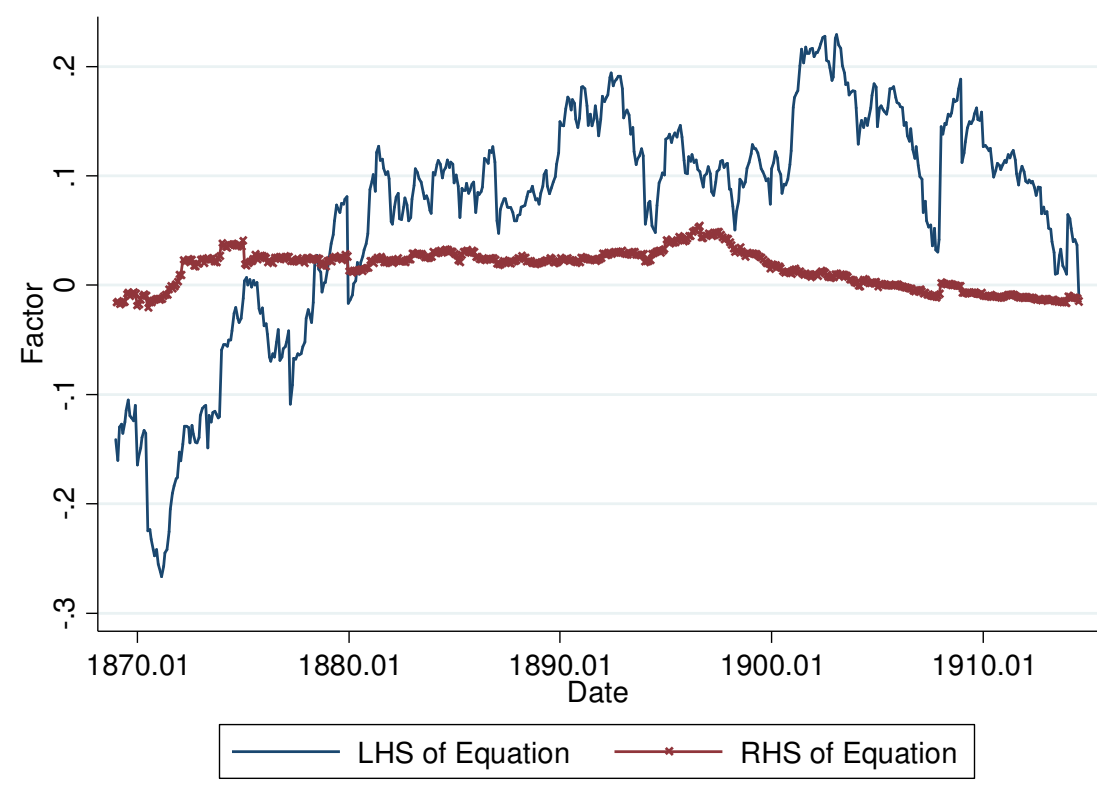

Figure 10: Equation 4 for Britain in the period $1869-1914$. Equation 4 is $\left(k g_{t}^{A}+i_{t}^{A}-\right.$ $\gamma)>\left(k g_{t}^{L}+i_{t}^{L}-\gamma\right)\left(L_{t-1} / A_{t-1}\right)$, where $k g_{t}^{A}, i_{t}^{A}, k g_{t}^{L}, i_{t}^{L}, \gamma, L_{t-1}$ and $A_{t-1}$ are respectively capital gains on assets, dividend yields / interest rates on assets, capital gains on liabilities, dividend yields / interest rates on liabilities, nominal growth rate of GDP and external liabilities and external assets.

On average, the pure exorbitant privilege enjoyed by Britain was strong enough to manifest itself in aggregate terms. The aggregate revenues received by Britain were larger than the estimates for the US in the last quarter of the twentieth century and represented by themselves a significant macroeconomic value, comparable for example to the investment component of the GDP of many countries. In the next chapter, I further explore the implications and nuances of British exorbitant privilege. 


\section{Chapter 4: Further Analysis of Exorbitant Privilege}

The main result of chapter 3 is that Britain enjoyed a significant exorbitant privilege. In this chapter, I analyze several issues related to the existence of exorbitant privilege. The first section deals with inflation differentials. The main goal is to assess if inflation differentials are a cause of nominal returns differentials, a step ahead from the international finance literature. The section that follows reproduces analysis from the international finance literature in order to understand the channels through which British exorbitant privilege manifested itself. The two final sections study the importance of the size of Britain's net external position, Britain's status of creditor (instead of debtor, as is the case for the US in the last quarter of the twentieth century) and the currency composition of Britain's net external assets as a factor underlying the existence of British exorbitant privilege.

\section{$\underline{\text { Inflation }}$}

An important observation with respect to the rates of return calculated above is that they are nominal, since information contained in the IMM are nominal. Dividend yields and capital gains are calculated by using nominal values of capital for each security. A possible explanation for the difference in nominal returns between securities of two countries could be the difference in inflation rates between countries. British investors could demand a higher nominal return from securities of other countries to assure that they would be receiving a similar real return to British securities. The difference in returns would be purely a difference in nominal returns. The exorbitant privilege literature with respect to the US calculates nominal returns and the compatibility between estimates of returns for Britain in the period 1870-1914 
and the US in the last quarter of the twentieth century is the main reason to calculate nominal returns to Britain. ${ }^{48}$ The advent of persistent high inflation occurs in the twentieth century after the Second World War, which means that it is a more serious issue for estimates of returns in the last quarter of the twentieth century than before the First World War. ${ }^{49}$

Securities denominated in pounds sterling from foreign countries are protected from inflation. In theory, other securities could be vulnerable, but persistent higher rates of inflation with respect to other countries should not be a frequent event under the gold standard, since the discrepancy of prices would create a deficit in the trade balance and trigger gold movements. A complete comparison of real rates of returns across the globe is not the objective of this section. Instead, I focus on the rates of inflation of Britain and the US. Data availability and the position of the US as the largest destination of British capital and the country with the most non pounddenominated securities determine the choice of the US.

Figure 11 plots price indexes for the two countries (indexes with the base-year of $1873=100$ in the panel above and rates of inflation year over year in the panel below) ${ }^{50}$ In the beginning of the period, the US prices fell (possibly as a correction for high inflation during the Civil War). From 1873 to 1895 , both countries followed

\footnotetext{
${ }^{48}$ The calculation of inflation differentials is the first necessary step for future work that tries to explain exorbitant privilege empirically.

${ }^{49}$ Here I make a difference between persistent high inflation that was experienced in several countries in the second half of the twentieth century (such as the extreme experience of Brazil until 1994) and hyperinflation episodes, such as the one experienced by Germany between the wars.

${ }^{50}$ Series for the US are the average of three indexes contained in Carter et al. (2006): the General Price Index (Snyder-Tucker), the Wholesale Price Index All Commodities (Warren and Pearson) and the Wholesale Price Index (Bureau of Labor Statistics). Series for Britain are the average of three indexes contained in Mitchell (1988): the Rousseaux Price Indices, the Sauerbeck-Statist Price Indices and the Board of Trade Wholesale Price Indices.
} 
similar dynamics and experienced strong deflation. From 1895 to 1900 , inflation is positive again in both countries. The first large divergence occurs from 1900 to 1905, when the US experiences inflation and British prices are stable. From 1905 to 1914, both countries experience positive inflation, with a higher average in the US. At least for the period analyzed, inflation differentials between the two countries do not seem to be significant or a major cause for nominal returns differentials. The period between 1900 and 1905 is the only one with a substantial inflation differential. Another interesting aspect of the period 1873 to 1895 is that nominal rates of return are higher than ex-post real rates of return (using realized inflation to calculate the real rates of return). ${ }^{51}$ Average inflation rate for the period $1872-1914$ is $-0.4 \%$ for the US and $-0.5 \%$ for Britain.

\footnotetext{
${ }^{51}$ Persistent deflation affects expectations as well. If estimates of expectations of inflation were available, ex-ante real rates of return would be higher than nominal rates of return.
} 

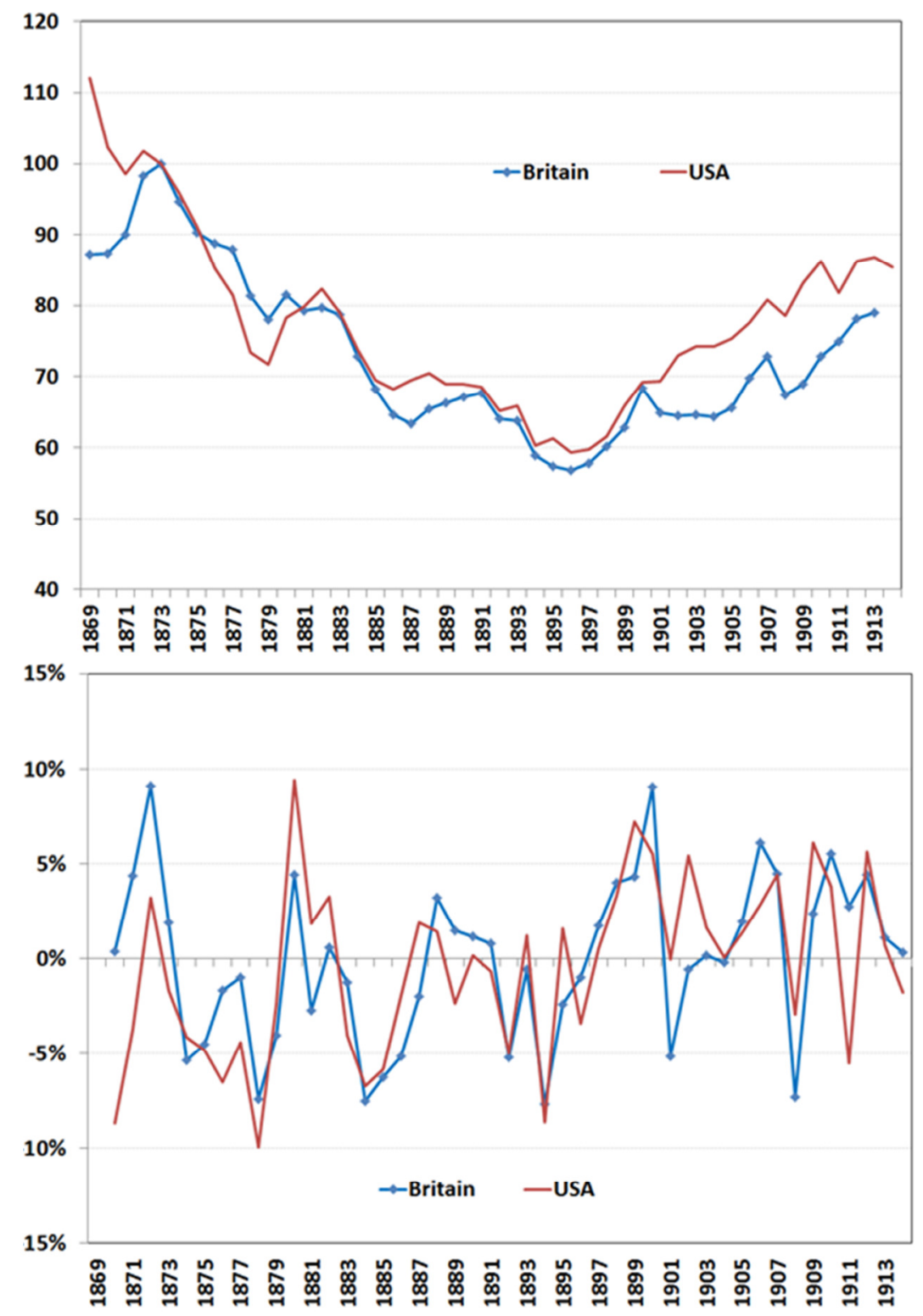

Figure 11: Prices in Britain and the US. Panel A (above): Average of price indexes (1873=100). Panel B (Below): Inflation Year over Year. Sources: Mitchell (1988) for Britain and Carter et al. (2006) for the US.

\section{Composition and return effects for capital gains}

GR (2007) decompose excess returns in the US in the second half of the twentieth century into total return and composition effects. They find that in the case 
of the US, external assets are dominated by classes of assets with higher risk profile than those of external liabilities. Figure 12 shows the composition of British securities (government and railroads) in the top panel and of foreign securities (government and railroads) in the lower panel. The top panel represents the portfolio composed of British external liabilities and the lower panel the portfolio composed of British external assets. ${ }^{52}$ The usual ascendant scale of risk goes from debt (which promises a fixed return to the investor) to preferred shares (which promise a fixed return after the payment of bonds) and to common shares (the residual receivers of eventual profit distribution). The first important aspect to notice in the two panels is the relative dominance of debt instruments. The share of debt is higher than $85 \%$ in the lower panel and ranges from $80 \%$ to $60 \%$ in the upper panel. The immediate conclusion from Figure 12 is that there is a large difference between the composition of British external assets and British external liabilities. Taking into account that debt securities are associated with a lower profile of risk, the figure suggests that Britain's profile was the inverse of the US of the late twentieth century: external assets were dominated by classes of securities with a lower risk profile than those of external liabilities. $^{53}$

\footnotetext{
${ }^{52}$ In order to carry out the analysis presented in this section, I assume that foreign investors bought British assets in a fixed proportion with respect to the total amount traded at the LSE. For example, investors would hold portfolios composed of 50\% of British government securities and $50 \%$ of British railway securities. This might not be true, since foreign investors may have been biased to one type of British security. If that security was government bonds, the estimates presented here are a lower bound of the possible range for the composition effect.

${ }^{53}$ This is compatible to evidence that British investors preferred debt securities. See Platt (1986).
} 

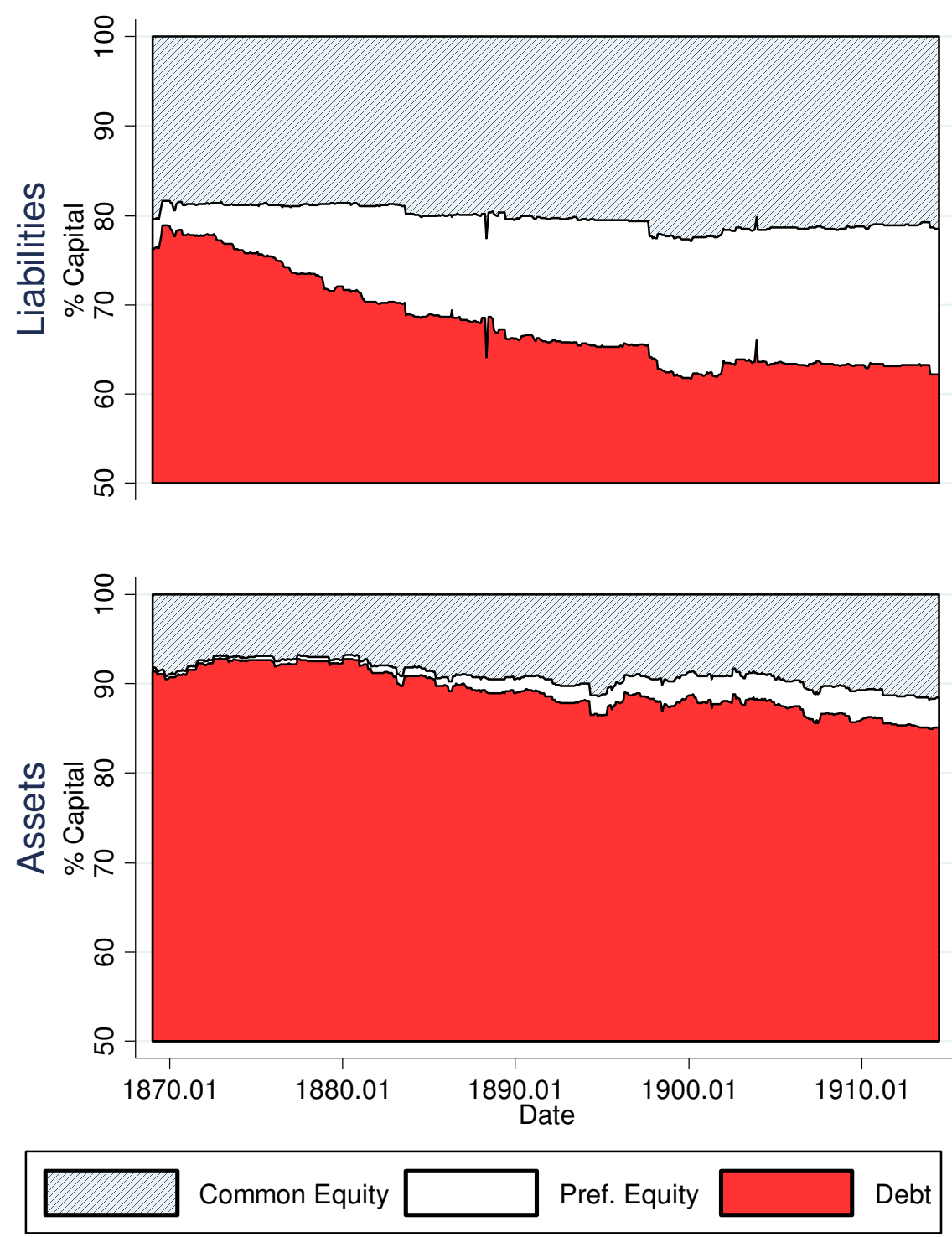

Figure 12: Composition of portfolios in terms of class of assets. (In black and white charts, debt is the area below).

Table 5 and Figure 13 present the decomposition of total excess returns (capital gains + dividend yields) on British net external assets into the composition effect and the total return effect, following equation 5: 


$$
\underbrace{r^{A}-r^{L}}_{\text {Total Exess Returns }}=\underbrace{\sum_{j} \frac{\left(\alpha_{j}+\lambda_{j}\right)}{2}\left(r_{j}^{A}-r_{j}^{L}\right)}_{\text {Total Return Effect }}+\underbrace{\sum_{j}\left(\alpha_{j}-\lambda_{j}\right) \frac{\left(r_{j}^{A}+r_{j}^{L}\right)}{2}}_{\text {Composition Effect }}
$$

The total excess return here corresponds to a weighted exorbitant privilege, since I am not taking into account that British assets are much larger than British liabilities. ${ }^{54}$ The total return effect is the difference between returns of assets and liabilities within each class of asset (sovereign, railroad debt, railroad common equity, and railroad preferred equity), not taking into account the shares of each class of asset in the composition of assets and liabilities. As an example, the difference in returns between British railroad common equity and foreign railroad common equity contributes to the total return effect.

The composition effect is the difference in returns caused by differences in the composition of the asset and liability portfolios. If external assets are less concentrated in equity than external liabilities, the difference between the share of equity in assets and the share of equity in liabilities is negative. For example, if equities are $10 \%$ of assets and $30 \%$ of liabilities, the difference is $-20 \%$. The composition effect for equity is $-20 \%$ multiplied by the average of the returns of equities on assets and equities on liabilities. Given the returns on individual asset classes (the average between the returns of the same class in assets and liabilities),

\footnotetext{
${ }^{54}$ The difference between British and American relative sizes of gross external assets and liabilities is important. While for the US gross external liabilities are 1 to 1.5 times the size of the gross external assets (175\% of GDP compared to 150\% of GDP on average from 1990 to 2004), for Britain gross external assets were probably more than 10 times higher than gross external liabilities during this period (180\% of GDP compared to $10 \%$ of GDP). While GR (2007) were giving equal weight to comparable magnitudes (150\% of GDP and $175 \%$ of GDP), I am giving equal weights to completely different magnitudes. The direct consequence is that some of the results might be counterintuitive. This is the spirit of the difference between weighted exorbitant privilege and aggregate exorbitant privilege.
} 
the different compositions of assets and liabilities generate different aggregate returns.

Given the composition of UK's external assets and liabilities in Figure 12, it is no surprise that the composition effect is negative: the portfolio composed of British external assets is less risky than the portfolio composed of British external liabilities. A large part of the result comes from railroad equity securities, while sovereign securities present a positive composition effect for most decades (since sovereign securities are all debt). The total return effect on British net external assets derives from the difference in returns within each class of asset and not from the different composition of assets and liabilities. Since the composition effect is negative, positive total excess returns mean that the return effect is positive and large. The overall total excess return is positive $(0.1 \%)$, but this is a result largely of the decade from 1900 to 1909 . For those years, the total return effect was 5.8\%, boosted by strong returns in railroad securities of all classes. In most other decades, the total return effect is positive but not large enough to compensate for the negative composition effect. The results for the total return effect are compatible in terms of overall magnitude with the findings of GR (2007) and Habib (2010) for the US in the last quarter of the twentieth century. Because the composition effect for the US is positive and for Britain is usually negative, the overall total excess return for Britain is smaller than for the US in the twentieth century. The fact that the total return effect is positive confirms the findings of Table 3 about pure exorbitant privilege: British securities paid a lower return than comparable foreign securities. Nonetheless, the fact that British 
invested mainly in safe assets (debt) took away part of the benefit of issuing the global reserve currency. ${ }^{55}$

\begin{tabular}{|c|c|c|c|c|c|c|c|}
\hline & & $1869-1879$ & $1880-1889$ & 1890-1899 & $1900-1909$ & $1910-1914$ & Total \\
\hline \multirow{6}{*}{$\begin{array}{c}\text { Composition } \\
\text { Effect }\end{array}$} & RR Equity (Com.) & -1.2 & -1.0 & -1.0 & -1.2 & -0.6 & -1.1 \\
\hline & RR Equity (Pref.) & -0.8 & -2.2 & -1.3 & -1.2 & -0.5 & -1.3 \\
\hline & RR Debt & 0.2 & -0.1 & 0.0 & 0.0 & 0.1 & 0.0 \\
\hline & RR Total & -1.8 & -3.3 & -2.3 & -2.4 & -0.9 & -2.3 \\
\hline & Sovereign & 0.5 & 1.0 & 0.7 & 0.7 & 0.0 & 0.6 \\
\hline & Total & -1.3 & -2.3 & -1.6 & -1.8 & -0.9 & -1.6 \\
\hline \multirow{6}{*}{$\begin{array}{c}\text { Total Return } \\
\text { Effect }\end{array}$} & RR Equity (Com.) & -0.5 & -0.6 & 0.2 & 2.2 & 0.2 & 0.3 \\
\hline & RR Equity (Pref.) & -0.1 & 1.2 & 0.3 & 0.9 & -0.4 & 0.4 \\
\hline & RR Debt & -0.7 & -0.4 & 0.0 & 1.2 & -0.1 & 0.0 \\
\hline & RR Total & -1.4 & 0.1 & 0.5 & 4.3 & -0.3 & 0.7 \\
\hline & Sovereign & 0.3 & 2.0 & 0.6 & 1.5 & 0.7 & 1.0 \\
\hline & Total & -1.0 & 2.1 & 1.1 & 5.8 & 0.4 & 1.8 \\
\hline \multirow{3}{*}{\multicolumn{2}{|c|}{$\begin{array}{l}\text { RR Total Excess Return } \\
\text { Sov. Total Excess Return } \\
\text { Total Excess Return }\end{array}$}} & -3.2 & -3.2 & -1.8 & 1.8 & -1.2 & -1.6 \\
\hline & & 0.8 & 3.0 & 1.3 & 2.2 & 0.7 & 1.7 \\
\hline & & -2.3 & -0.2 & -0.5 & 4.0 & -0.5 & 0.1 \\
\hline
\end{tabular}

Table 5: Average yearly returns for each class of asset by decade.

The results of Table 5 are presented graphically by year in Figure 13. The strong contributions to the total return effect of railroad securities are observable in the years of 1900, 1901 and 1908 . Sovereign securities usually contribute to a positive composition effect while railroad common stocks usually make a negative contribution to the composition effect. For most years, the components are between $5 \%$ and $+5 \%$ but there are extremes of almost $-15 \%$ and $+15 \%$.

\footnotetext{
${ }^{55} \mathrm{I}$ am not claiming that investment in safe assets is a flawed strategy. I am just claiming that Britain did not take advantage of the spread between the returns on its assets and liabilities.
} 


\section{Total Return Effect}
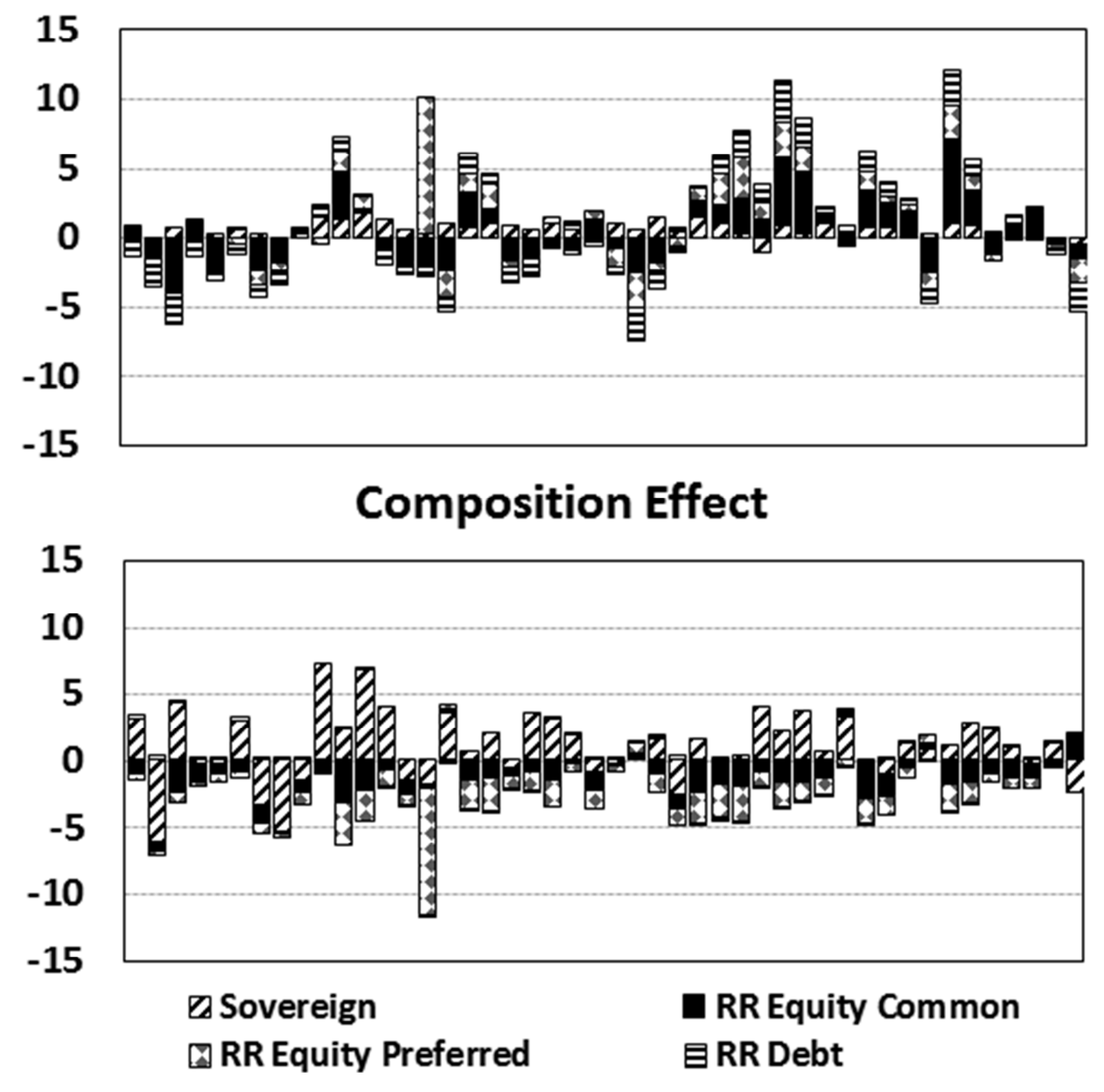

Total Excess Return

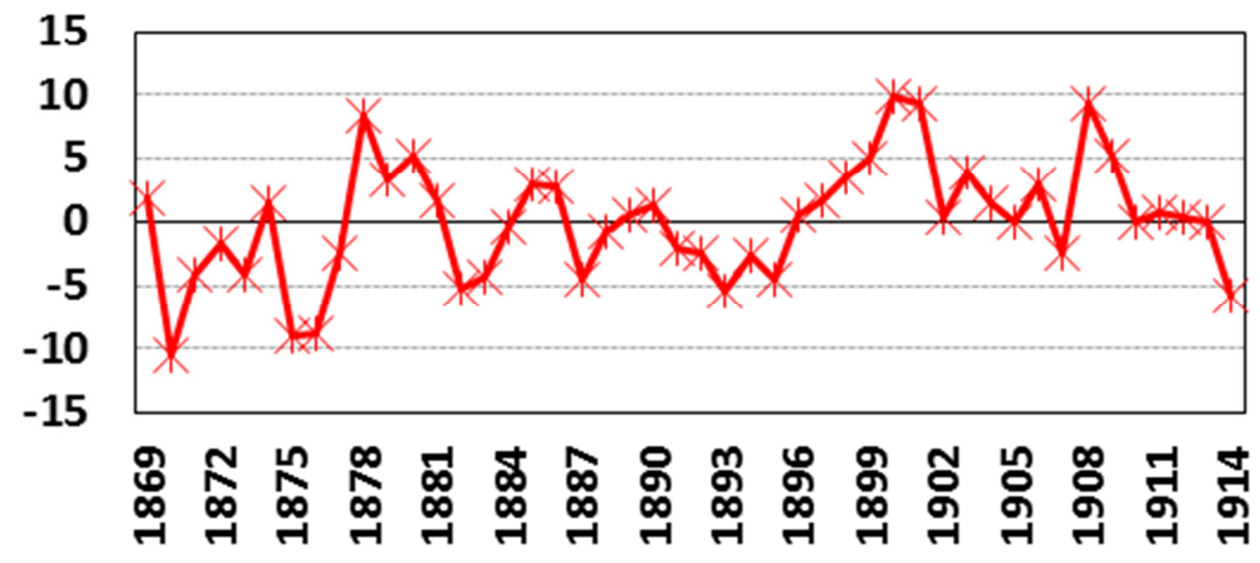

Figure 13: Composition of average annualized monthly returns by year Separating between returns and aggregate positions 
It is clear from the last section that the overall excess returns from the British net external position were positive but very low, because Britain's external asset position was less risky than Britain's external liabilities position. With a low total excess return $(0.1 \%)$, how is it possible that Britain received a large amount of revenues from the rest of the world? The answer is that Britain was a surplus country and accumulated a large net external position, which reached around $180 \%$ of GDP on the eve of the First World War. By contrast, the US has maintained a large negative external position in recent decades. Is it possible that Britain received large aggregate revenues from the rest of world simply because its large positive net external position leveraged small excess returns? Figure 14 answers this question by plotting three series. The first one ("Actual") is the actual ratio of liabilities over assets derived from my data. The second one ("No Income") is the ratio of liabilities over assets that would make the right-hand side of Equation 4 equal to the left-hand side of Equation 4, given the (monthly) returns calculated for Figure $10{ }^{56}$ For example, if returns on aggregate assets are $1.1 \%$ and returns on aggregate liabilities are $1 \%$ (meaning that excess returns are $0.1 \%$ ), the left-hand side of equation 4 is 0.011 and the right-hand side is $0.01 *\left(L_{t-1} / A_{t-1}\right) .{ }^{57}$ In order for the left-hand side to be equal to the right-hand side, the ratio of liabilities over assets $\left(L_{t-1} / A_{t-1}\right)$ has to be $110 \%$. If returns on liabilities are higher than returns on assets, the ratio of liabilities over assets will be lower than $100 \%$ (and the country has to be a net creditor to receive a positive income from the rest of the world). The chart also

\footnotetext{
${ }^{56}\left(L_{t-1} / A_{t-1}\right)=\left(k g_{t}^{A}+i_{t}^{A}-\gamma\right) /\left(k g_{t}^{L}+i_{t}^{L}-\gamma\right)$ given $k g_{t}^{A}, i_{t}^{A}, k g_{t}^{L}, i_{t}^{L}$ calculated for Figure 10 .

${ }^{57}$ Returns were already discounted of the nominal growth of GDP for this calculation.
} 
depicts the ratio of liabilities over assets for the US for the period 1982-2004 (the line was "stretched" in order to compare to Britain, so that one year for the US series in the lower axis corresponds to two years of the two British series in the upper axis). From the series "Actual", Britain maintained a large and growing creditor position with the ratio of liabilities over assets falling from $30 \%$ to close to $10 \%$ over the period. From the series "No Income" and given the capital gains and dividend yields on assets and liabilities, the ratio of liabilities over assets needed to equalize returns on Britain's assets and liabilities would be below $100 \%$ for most of the period. Britain would not have been able to sustain a negative net external position during this period. This pattern changed after 1900, which is in accordance with the results of Table 5. The US has been able to maintain a negative net position that was not sustainable by Britain, given the low excess returns (in comparison to the US) that the latter received. Britain received large revenues from the rest of the world because of its large and positive net external position, but the net returns on its external position would have not allowed Britain to reach the status of a debtor country receiving positive revenues from the rest of the world until 1900. The source of British income from its external position is the difference between the blue line ("No Income") and the orange line ("Actual") in Figure 14. The greater is the difference between the two lines, the larger is the leveraging of a small returns differential by a large positive stock position. After 1900, Britain would have been able to be a debtor country receiving positive revenues, and is it is possible that its ratio of liabilities to assets would have smoothly increased if not for the interruption of the First World War. 


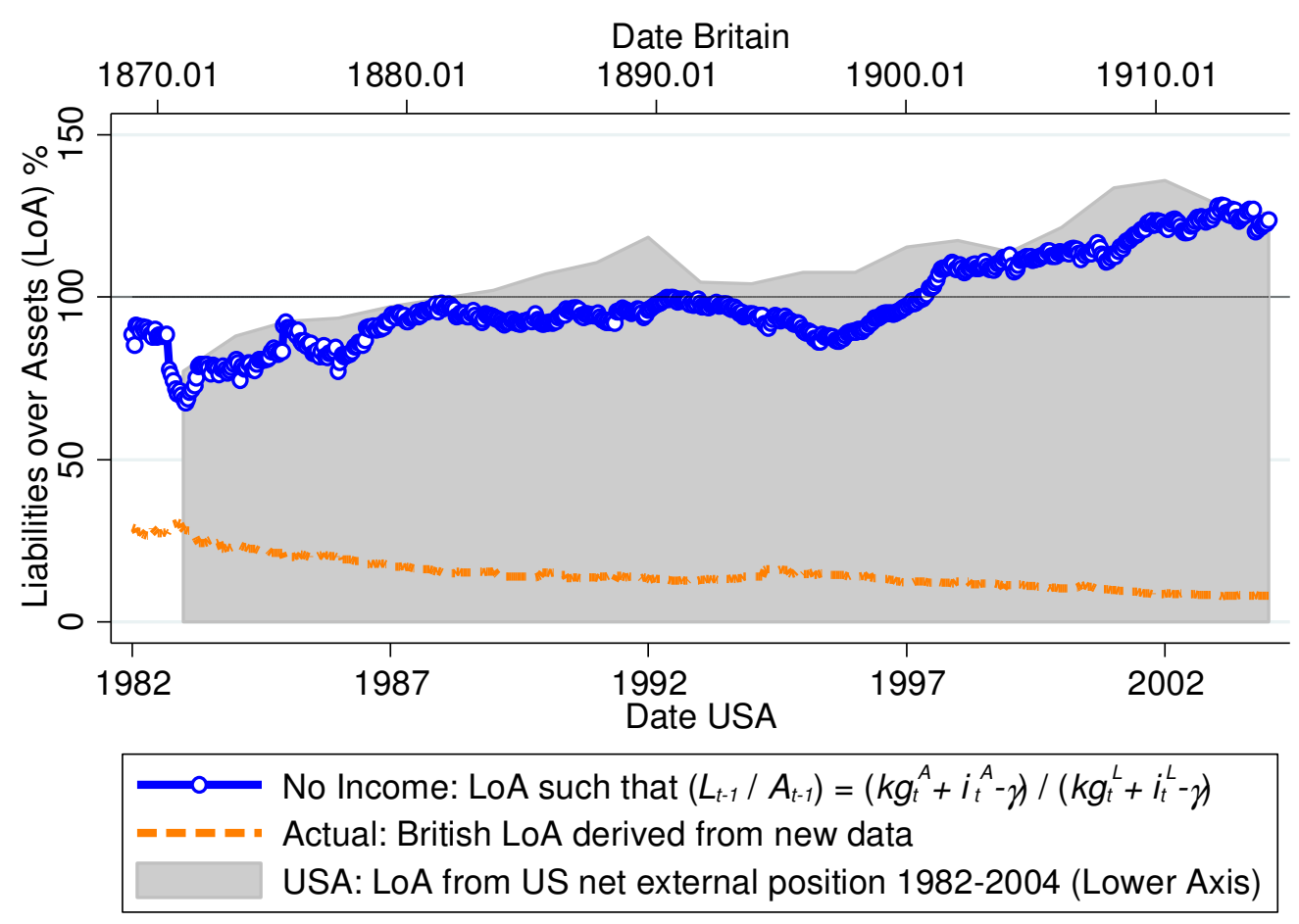

Figure 14: Comparison of actual British Liabilities over Assets (1871 - 1914) to simulated British Liabilities over Assets with no income and US Liabilities over Assets (1982 - 2004).

\section{Currency returns}

This section investigates returns differentials between currencies. The country that issues the global reserve currency derives an advantage because its liabilities are denominated in the global reserve currency while its assets are denominated in other currencies. The case of Britain is distinct for two reasons. The international monetary arrangement was the gold standard, which meant that most currencies in the world operated under a system of fixed exchange rates. Each currency in theory would be equivalent to the pound sterling, since it was convertible into gold and gold was convertible into pounds sterling. The main risk to the investor originated from the possibility of a country leaving the gold standard. The other main point is that the 
majority of the foreign securities traded in London were denominated in pounds, and the majority of the securities denominated in other currencies contained gold and sterling clauses. Considering these two caveats, Figure 15 presents the breakdown of Figure 9 into securities denominated in pounds and securities denominated in other currencies. ${ }^{58}$ Even though they comprised a minority of the securities traded at the LSE, securities denominated in other currencies represent a significant share of net returns after 1900, while the net returns from pound denominated securities gradually decreased. The shift in excess returns after 1900 comes from securities denominated in other currencies. Had the new trend been maintained after 1914, Britain could have received a growing benefit from its external asset position.

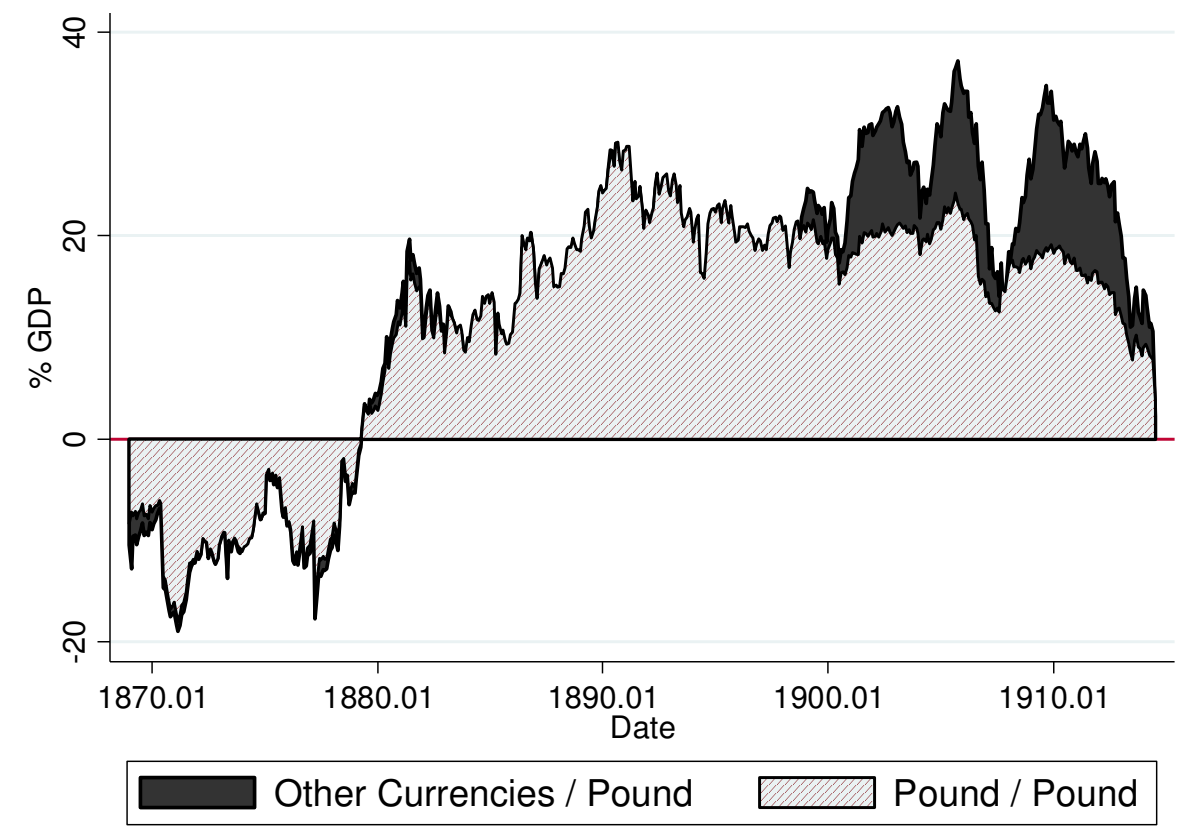

Figure 15: Measure of net revenues earned by Britain vis-a-vis the rest of the world (aggregate exorbitant privilege): breakdown between foreign securities in pounds and foreign securities in other currencies.

\footnotetext{
58 The breakdown is from assets' revenues since all the liabilities are denominated in pounds.
} 
In this chapter, I analyzed several important qualifications to the result on exorbitant privilege from chapter 3. The excess returns on Britain's net external position were low when compared to the US. Britain invested in safer assets, which meant that it dissipated part of the advantage of issuing the global reserve currency. Britain still received large net revenues from the rest of the world, due to its large positive external position. After 1900, the currency composition and the estimation of the maximum sustainable ratio of liabilities over assets indicate that the structure of the external position was changing. Britain might have been able to sustain a debtor position with positive revenues from the rest of the world in the long run. 


\section{Chapter 5: Data}

This chapter provides a detailed description of the data sources in order to facilitate its use in future research. I also explain the procedures used for cleaning and organizing the data. Two preliminary sections follow. The first one examines the role of the London Stock Exchange as the global conduit of British capital. The next one clarifies the classification of capital between direct and portfolio investment for the period 1870-1914 and highlights the importance of portfolio flows as the prime type of British exports of capital. The main point of the two sections is to justify the use of the data from the LSE as a good proxy for calculating the British external position.

\section{London Stock Exchange}

Britain was the most advanced economy of the time and the London Stock Exchange (LSE) was the largest and most liquid exchange in the world by far. According to Davis and Gallman (2001, page 182), in 1910 one-third of the paid-up value of all negotiable securities on the planet were quoted on the LSE. The London Stock Exchange was the international stock exchange. Foreign companies (for example, American railroads) issued securities there. In comparison, the New York Stock Exchange was almost exclusively a market for domestic securities. Investors from other countries, such as France, utilized the services of the LSE when composing their investment portfolios. As Platt (1986) points out: "The existence of so much foreign business in London was the reason why the LSE was closed on 31 July 1914, only three days after the Austrian declaration of war on Serbia, when resident foreign firms found it impossible to collect what was due to them from 
abroad." Besides lower tax rates, British investors enjoyed cultural proximity and knowledge of the most active financial sector of the time: American railroad securities. ${ }^{59}$ Platt lists the convertibility of the pound sterling and Britain's worldwide network of shipping, trade and finance as other factors that made London a "home for funds irrespective of interest rates." The British legal system should be added to that list.

\section{$\underline{\text { Portfolio and Direct Investment Flows }}$}

The export of British capital primarily took the form of portfolio investment. The IMF's Balance of Payments Manual defines portfolio investment as "transactions and positions involving debt or equity securities". Also according to the Manual, securities "have the characteristic feature of negotiability. That is, their legal ownership is readily capable of being transferred by delivery or endorsement". Platt estimates that direct investment (the other main foreign investment category besides portfolio investment) was only $8 \%$ to $15 \%$ of total British investment overseas. ${ }^{60}$

With respect to the most important destination of British foreign railroad investments for this period, Wilkins (2009) affirms, "it has long been accepted that in the late nineteenth and early twentieth centuries, the value of foreign portfolio investment far exceeded that of foreign direct investment in the United States." ${ }^{, 61}$

\footnotetext{
${ }^{59}$ The Appendix contains an analysis of this important sector with the new data presented here.

${ }^{60}$ The formal definition according to the Manual is "Direct investment is a category of cross-border investment associated with a resident in one economy having control or a significant degree of influence on the management of an enterprise that is resident in another economy."

${ }^{61}$ The type of investment probably varied with the destination. American firms issued securities in London (portfolio flows) but British investors formed and managed companies in Latin America (which constitutes direct investment). A high share of direct investment in total investment can be an indicator of low trust in local institutions, as analyzed in Hausmann and Fernandez-Arias (2000) and discussed in Araujo et al. (2015).
} 
According to Platt, the definition of direct investment employed before 1914 was capital invested privately that did not pass through a public stock exchange, or "investment that did not leave traces in the securities markets". However, according to modern practice, some investments in securities are classified as direct investment if the share acquired by the investor is high enough to guarantee operational control of the firm (the threshold is $10 \%$ ). After describing the methodology they used for equity, Lane and Milesi-Ferretti (2001) say: "Given that the difference between portfolio equity investment and FDI can be blurred in some cases, we would ideally want to estimate both stocks according to the same methodology." Part of the investments registered as portfolio before 1914 would be classified as direct investment in modern terms, which means that the LSE captured some of what is now considered direct investment.

Since Britain was the largest exporter of capital for the period analyzed and the largest share of this investment was in the form of portfolio securities, the London Stock Exchange was the natural conduit through which those resources reached their destinations. This is fortunate, since the data coming from organized markets are the best available in terms of quality and standardization. Portfolio data also contain two classes of assets with different profiles of risk: debt and equity. This provides a minimum variety of classes to assess overall portfolio positions.

My primary data source is the Investor's Monthly Manual (IMM) from 1869 to 1914 . The IMM was a monthly publication providing financial information to capital market investors. It has been used extensively as a data source for studying nineteenth century capital flows in the economic history literature. The IMM listed all 
the securities traded on the London Stock Exchange and other local British stock exchanges, including stocks and bonds along with specific information described in the next sections. ${ }^{62,63}$ The International Center for Finance (ICF) of the Yale School of Management recently digitalized the pages of every issue of the IMM from 1869 to 1929 and transformed the data into an electronic database.

The second data source is the Stock Exchange Yearbook (SEY). ${ }^{64}$ It was an annual publication with the purpose of serving as a compendium of information for the securities listed in the London Stock Exchange. The annual SEY is a perfect complement to the more timely IMM, since it contained detailed information in the form of text for each company and security. Figure 16 and Figure 17 contain respectively samples of the IMM and the SEY ${ }^{65,66}$

\footnotetext{
${ }^{62}$ The IMM is a precursor of modern financial information systems such as Reuters and Bloomberg. Besides the Stock Exchange Yearbook mentioned below, another source of information on securities traded in the LSE is the Stock Exchange Intelligence (also known as Burdett's Stock Exchange Intelligence).

${ }^{63}$ The nomenclature used in this chapter is modern. In the original data, a variety of names were used to denote fixed-income securities or securities founded in debt: sovereign bonds were called stocks, while railway bonds were called debenture stocks (and the coupon rate was stated in the name of the security). Securities modernly known as stocks or equities were usually called shares. Nonetheless, sometimes the expression capital stock was used. Shares were classified as ordinary, preference or deferred. Ordinary share or simply share corresponds to the modern common stock. Preference shares (or modernly preferred stocks) were securities with priority over common stocks on earnings after the payment of bonds (and usually had a fixed return rate). Deferred shares were securities that would be paid after common stocks. The existence of deferred shares had the practical effect of transforming common stocks into preferred stocks, since a threshold had to be established in order to start the payment of deferred shares. It is not clear how voting rights were distributed with respect to ordinary and preference shares.

${ }^{64}$ Microfilms of the editions of the Stock Exchange Yearbook from 1875 to 1895 were acquired and transformed into PDFs thanks to the generous support of the fellowship instituted by the family of Professor Allan G. Gruchy at the University of Maryland.

${ }^{65}$ The explanations of the next section contain expressions such as "last month", "current month" or "last year". Since this analysis refers to the content of an issue of the IMM, the reader should keep in mind that "last year" is the year before the year of publication of a specific IMM issue. On the same token, "last month" refers to the last month before the month of publication of an IMM issue.

${ }^{66}$ Grossman (2002) is a reference for the next section.
} 


\begin{tabular}{|c|c|c|c|c|c|c|c|c|c|c|c|c|c|c|c|}
\hline dug. 29, 1884.] & \multicolumn{14}{|c|}{ THE INVESTOR'S MONTHLY MANUAL. } & 393 \\
\hline \multicolumn{16}{|c|}{ BRITISH, COLONIAL, AND FOREIGN RAILWAYS-Continued. } \\
\hline \multirow[b]{2}{*}{ RAILWAYS. } & \multicolumn{3}{|c|}{ Capital. } & \multicolumn{4}{|c|}{$\begin{array}{l}\text { PRICES OF THK } \\
\text { MONTH. }\end{array}$} & \multirow{2}{*}{$\begin{array}{c}\text { Last } \\
\text { Busi. } \\
\text { ness } \\
\text { Done. }\end{array}$} & \multirow{2}{*}{\multicolumn{2}{|c|}{$\begin{array}{l}\text { Last two } \\
\text { divs. yld } \\
\text { Investor } \\
\text { at Latest } \\
\text { Price. } \\
\text { PerCent. }\end{array}$}} & $\begin{array}{l}\text { Pricks OF } \\
1884 .\end{array}$ & & Drvi & IIDENDS. & \\
\hline & $\underset{£}{\text { Subscribed }}$ & $\begin{array}{c}\text { Amt } \\
\text { of } \\
\text { Share }\end{array}$ & Par. & r. & 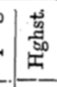 & 雚 & 苞 & & & & $\mid \begin{array}{l}0 \\
0 \\
0 \\
0 \\
0 \\
0\end{array}$ & & $\begin{array}{l}\text { Last } \\
\text { Rate per Cent } \\
\text { Interim. }\end{array}$ & $\begin{array}{l}\text { Four. } \\
\text { at. per Annu } \\
\dagger \text { per Shar }\end{array}$ & n. \\
\hline Argentine,L., $-6 \%$ deb. stock ... & 317,000 & & 100 & 103 & 104 & 102 & 103 & $103 \ddagger$ & & & & & & & \\
\hline land $4.1 \%$ deb. $s$ & 668,000 & 20 & 20 & 18 & $19 d$ & & & $19^{\circ}$ & 617 & $021 \frac{1}{4}$ & $\frac{1}{4} \mid 7 \frac{1}{2}$ & & 10. & $\begin{array}{ll}3 & 6 \frac{1}{2} \mathrm{Jne} \\
\end{array}$ & \\
\hline $\begin{array}{l}\text { Eastern \& Midl } \\
\text { Do } 5 \% \text { Prefer }\end{array}$ & $\begin{array}{l}393,362 \\
10000\end{array}$ & $\cdots$ & 100 & 87 & 89 & $85^{\circ}$ & $87 \frac{1}{2}$ & $\frac{1}{2}$ & 53 & 0103 & & $4 \frac{1}{2} J$ an. 83 & 33| 41.July83 & & \\
\hline Do $5 \%$ Preference 18 & $\begin{array}{l}100,0 \\
150,0\end{array}$ & $\cdots$ & $\begin{array}{l}100 \\
100\end{array}$ & $\cdots$ & $\cdots$ & $\cdots$ & & $95 \frac{1}{2}$ & $\ldots$ & 105 & 85 & & $\ldots$ & 5 Aug 8: & 5 Feb.84 \\
\hline Do ORDinary Stock & 610,714 & $\cdots$ & 100 & $\cdots$ & $\cdots$ & $\cdots$ & $\cdots$ & $\cdots$ & $\cdots$ & & $\cdots$ & & & $\cdots$ & \\
\hline $\begin{array}{l}\text { Eastern } \\
\text { Do } 4^{\circ}\end{array}$ & 411,305 & $\cdots$ & 100 & 108 & $\cdots$ & $\cdots$ & 108 & 108 & 314 & 1110 & 103 & 4 Jan. 83 & 3 4 July83 & $3 \mid 4 \operatorname{Jan} 84$ & 4 July84 \\
\hline $\begin{array}{c}886 \\
\ldots .\end{array}$ & 409,700 & $\cdots$ & 100 & $\cdots$ & $\dddot{26}$ & $\dddot{25}$ & $\dddot{2}$ & $\dddot{2}_{53}$ & $\cdots$ & $\cdots$ & $\cdots$ & 4 Jan. 82 & :2 4 July 83 & 3. 4 Jan. 84 & \\
\hline Do A Annuities & $\cdots$ & & $\cdots$ & $\cdots$ & $\begin{array}{l}26 \\
\ldots\end{array}$ & $\begin{array}{l}25 \\
\ldots\end{array}$ & $\begin{array}{l}25 \frac{1}{4} \\
25 \frac{1}{4}\end{array}$ & 25 년 & $\cdots$ & & $\cdots$ & & $\cdots$ & $\cdots$ & \\
\hline Eastern of France $5 \%$ red. obligations & $\begin{array}{ll} & 7,026,919 \\
\end{array}$ & $\dddot{20}$ & 20 & $\dddot{22} \frac{7}{8}$ & & $\cdots$ & $22 \frac{4}{3}$ & 227 & 47 & E 24 & 22 & 5 Dec. 82 & 2 5 Jne.83 & 5 Dec.83 & 5 Jne. 84 \\
\hline .............. & $26,583,400$ & 12 & 12 & $144^{2}$ & 15 & $14 \frac{1}{2}$ & $144^{\circ}$ & $143^{3}$ & 414 & 115 & $13 \frac{3}{4}$ & & & & \\
\hline Do o & $6,136,317$ & 12 & 12 & 148 & & & 148 & $14 \frac{5}{8}$ & 42 & \begin{tabular}{l|l}
0 & 145 \\
0
\end{tabular} & $13 \frac{2}{4}$ & & & 5 Sep. 83 & \\
\hline Do s & $11,680,000$ & 20 & 20 & $30 \frac{1}{4}$ & 31 & 30 & $30 \frac{1}{2}$ & 2) $30 \frac{1}{2}$ & 46 & 6 $31 \frac{1}{2}$ & $\frac{1}{2} 28$ & 63 for 79 & 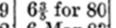 & & \\
\hline $\begin{array}{l}\text { Eastrn } \\
\text { East C }\end{array}$ & 6 630,900 & . $_{0}$ & 100 & $106 \frac{1}{2}$ & 107 & 105 & 106 & $107^{\circ}$ & 510 & $6 \mid 109^{2}$ & 102 & 6 Sep.82 & 26 Mar.83. & $6 \mathrm{~s}$ & \\
\hline $\begin{array}{l}\text { East Gloucestershire ordi } \\
\text { East Indian } 4 \frac{1}{2} \% \text { perpet. de }\end{array}$ & $\begin{array}{r}206,500 \\
1,500,000\end{array}$ & 10 & $\begin{array}{r}10 \\
100\end{array}$ & $12 \ddot{2}$ & $\ldots$ & $\cdots$ & $\ldots$ & 1204 & $s \dddot{1 s}$ & $s \mid \dddot{2} 2$ & 120 & $4 \frac{1}{2}$ Oct. 82 & & $4 \frac{1}{2} O$ & p. 84 \\
\hline $\begin{array}{l}\text { Do } 4 \frac{1}{\%} \text { Annuity } \mathrm{A} \text {, ceasing } 1953 \\
\text { Do def.ann.eap.g. } 4 \% \text { \& share profit }\end{array}$ & 272,306 & annual & al ly.] & 253 & 264 & t) $25 \frac{1}{2}$ & 26 & 26 & 311 & $c 26$ & $24 \frac{1}{2}$ & \&1 per & & annuity & \\
\hline $1900-1$ & $6,550,000$ & & 100 & 129 & 131 & 128 & 130 & 130 & 317 & o 136 & 127 & Fis & $35 \frac{7}{2}{ }_{5} \mathrm{July} 83$ & 3. 74 Jan. 84 & 6 July84 \\
\hline Do4l4s \% A & 624,901 & an'liy] & & $25 \frac{1}{4}$ & t) 26 t & 25 & 26 & 253 & $s 10$ & 6261 & 13. 231 & & & & \\
\hline East London & 465,590 & $\ldots$ & 100 & $160^{\circ}$ & 262 & 158 & 160 & $160^{\circ}$ & & $170^{\circ}$ & $157^{\circ}$ & 0 July 81 & 1 0 Jan & 0 July 82 & E4 Aug83 \\
\hline 1874, debenture s & 400,000 & $\cdots$ & 100 & 126 & 127 & 123 & 125 & 123 & nil. & 137 & 121 & Last & ent & July 1876 & $\cdots$ \\
\hline $\begin{array}{l}\text { Do } 6 \%, 1875 \text {, } \\
\text { Do } 3 \frac{1}{2} \%, 1881 \text {, guaranteed }\end{array}$ & 400,000 & $\ldots$ & 100 & 95 & 98 & 93 & 95 & 95 & nil. & 115 & 92 & $21 T$ & & $\mid \begin{array}{l}\text { July } \\
1876\end{array}$ & \\
\hline $\begin{array}{l}\text { Do } 3 \frac{1}{2} \%, 1881, \mathrm{~g} \\
\text { Do } 5 \% 1 \text { st pref }\end{array}$ & $\begin{array}{l}172,920 \\
400,000\end{array}$ & $\ldots$ & $\begin{array}{l}100 \\
100\end{array}$ & $\begin{array}{l}99 \\
36\end{array}$ & $\begin{array}{r}101 \\
39\end{array} \mid$ & $\begin{array}{l}98 \\
30\end{array}$ & $\begin{array}{c}100 \\
321\end{array}$ & $\begin{array}{r}100 \\
30\end{array}$ & $\begin{array}{l}310 \\
\text { nil. }\end{array}$ & c. $\begin{array}{r}103 \\
50\end{array}$ & $\begin{array}{l}94 \\
30\end{array}$ & $\begin{array}{l}\text { 31:Jan. } 83 \\
\text { nil. }\end{array}$ & $\begin{array}{l}3 \frac{1}{2} J \text { July } 83 \\
\text { nil. }\end{array}$ & $\mid \begin{array}{c}32 \mathrm{2} J a n .84 \\
\text { nil. }\end{array}$ & $\begin{array}{l}3 \frac{1}{2} J \text { uly84 } \\
\text { nil. }\end{array}$ \\
\hline Do 5 & 240,405 & $\cdots$ & 100 & $27 \frac{1}{2}$ & 30 & 25 & $27]_{i}^{2}$ & 27 & nil. & $\begin{array}{l}30 \\
40\end{array}$ & 22 & nil. & $\begin{array}{l}\text { nil. } \\
\text { nil. }\end{array}$ & $\begin{array}{l}\text { nil. } \\
\text { nil. }\end{array}$ & $\begin{array}{l}\text { nil. } \\
\text { nil. }\end{array}$ \\
\hline Do 0 & $1,400,000$ & & 100 & 21 & 22 & 19 & & 21 & mil. & 25 & 19 & nil. & & nil. & \\
\hline Finn V & 44,980 & 10 & 10 & $2 \frac{1}{4}$ & & & 21 & $2 \frac{1}{4}$ & nil. & & & p. 82 & ar 83 & ep. 83 & ir84 \\
\hline & $1,116,000$ & 10 & & $4 \frac{7}{16}$ & 5 & $4 \frac{7}{10}$ & 6 $\quad 4 \frac{3}{4}$ & 4 & $s 7$ & $4.8 \mathrm{p}$ & $\mathrm{kp}$ & $4 \mathrm{Ja}$ & & & \\
\hline tock & $1,443,091$ & $\ldots$ & 100 & 115 & 117 & 114 & $116^{\circ}$ & $115 \frac{8}{8}$ & $3 \quad 9$ & d $116^{2}$ & 108 & & & & \\
\hline Do & 779,125 & $\ldots$ & 100 & 110 & 112 & 109 & 111 & $110^{\circ}$ & 312 & 1112 & 106 & & & & \\
\hline Do 4 & $1,300,750$ & $\cdots$ & 100 & $104 \frac{1}{2}$ & 106 & 104 & $1055^{2}$ & 106 & 315 & 9.107 & $10 \Omega \frac{1}{2}$ & & & & \\
\hline $1881 \ldots$ & 350,000 & $\ldots$ & 100 & $105^{2}$ & 106 & 104 & 105 & 106 & 316 & 2106 & $101^{2}$ & 4 Jan. 83 & & 4 Jan. 84 & 4 July84 \\
\hline $\begin{aligned} \text { Do OK } \\
\text { Galvstn. }\end{aligned}$ & $2,642,000$ & $\cdots$ & 100 & 108 & 110 & $106 \frac{3}{2}$ & $\frac{1}{2} 108 \frac{1}{2}$ & $106 \frac{1}{2}$ & 47 & 2) 120 & 106 & $7 \frac{1}{2}$ Sep. 82 & $6 \frac{1}{2} \mathrm{Mar} 83$ & $4 \frac{1}{2}$ Sep. 83 & 5 Mar84 \\
\hline $\begin{array}{l}\text { Galvstn.,Hary } \\
\quad \text { 1st Mo }\end{array}$ & $\$ 4,500,000$ & $\$ 1,000$ & 0.1041 & 107 & 107 & 105 & 106 & $\$ 107$ & & 113 & 105 & & & $1=-2$ & Feb.;Ang \\
\hline Girvan and & 236,890 & 10 & 10 & & $\cdots$ & $\ldots$ & & 8 & nil. & $\begin{array}{c}110 \\
\cdots\end{array}$ & $\cdots$ & oupis & & nil & (2) \\
\hline $\begin{array}{l}\text { Glasgow and South- } \\
\text { and Maybole Junct }\end{array}$ & 34,500 & 10 & 10 & 19 & $19 \frac{1}{8}$ & & 9) $18 \frac{8}{4} x$ & & 314 & & & & & & \\
\hline Do St Enoch Station & $1,3 \varepsilon 5,000$ & $\ldots$ & 100 & 109 & & & 109 & 109 & $\begin{array}{lll}0 & 14 \\
3 & 18\end{array}$ & 5109 & $4 \begin{array}{r}16 \frac{2}{2} \\
1052\end{array}$ & \begin{tabular}{|ll}
4 & Feb. 83 \\
4 & Oct. 82
\end{tabular} & 24 & & \\
\hline & $2,087,592$ & $\ldots$ & 100 & $112 \frac{1}{2}$ & $115 \frac{1}{2}$ & 112 & $115 \frac{1}{2}$ & $112 \frac{1}{2}$ & 810 & d) $115 \frac{1}{2}$ & $107 \frac{2}{4}$ & & & & \\
\hline Dog & 935,450 & $\cdots$ & 100 & 110 & & & $110^{\circ}$ & $109 \frac{1}{2}$ & 312 & 0111 & 106 & & & & \\
\hline Do 1 & $1,892,150$ & $\ldots$ & 100 & 108 & $108 \frac{1}{2}$ & 108 & $108 \frac{1}{3}$ & $108 \frac{1}{2}$ & s 13 & 9 109련 & 106 & & & & \\
\hline 1885 & 61,650 & ... & 100 & 109 & $110^{-}$ & 109 & $109 \frac{1}{2}$ & $109 \frac{1}{2}$ & 318 & 6112 & 109 & & & & \\
\hline & 688,350 & 10 & 10 & $\begin{array}{r}13 \frac{1}{5} \\
53\end{array}$ & $\begin{array}{l}1 \\
3\end{array}$ & $\cdots$ & $13 \frac{1}{5}$ & $13 \frac{1}{8}$ & $S 17$ & 0 - 13 4 & $12 \frac{2}{5}$ & $5 \mathrm{~S}$ & & & \\
\hline Do 4 & $\begin{array}{r}630,000 \\
4,927,920\end{array}$ & $\begin{array}{l}10 \\
\ldots\end{array}$ & $\begin{array}{r}5 \\
100\end{array}$ & $\left|\begin{array}{r}5 s \\
111 \frac{1}{2}\end{array}\right|$ & 112 & 108 & $\begin{array}{r}58 \\
110^{8}\end{array}$ & 5 영 & 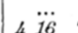 & 5 & $5 \frac{1}{8}$ & $51 \mathrm{Se}$ & & & \\
\hline Stock & $\begin{array}{r}4,927,920 \\
442,250\end{array}$ & $\cdots$ & 100 & 23 & $23 \frac{1}{2}$ & 20 & $\begin{array}{c}110 \\
201\end{array}$ & $\begin{aligned} 111 \frac{1}{2} \\
23 \frac{1}{1}\end{aligned}$ & 416 & & 106 & & & & \\
\hline & $\begin{array}{r}442,250 \\
85,000\end{array}$ & io & 10 & $11 \frac{8}{4}$ & & & 1113 & $23 \frac{1}{8}$ & $\begin{array}{rr}1 & 4 \\
5 & 19\end{array}$ & \begin{tabular}{l|l}
4 & 25 \\
0 & $\ldots$
\end{tabular} & 20 & $\frac{1}{2}$ Sep. 82 & $2 \mid \frac{1}{2} \operatorname{Mar} 83$ & ep: 83 & \\
\hline ..... & $\begin{array}{r}85,000 \\
130,000\end{array}$ & $\cdots$ & 100 & $96^{\circ}$ & 97 & 95 & 96 & $\dddot{96}$ & 65 & $0 \ddot{98}$ & $\dddot{9 i}$ & $\cdots$ & $\ldots$ & 6 Jan. 84 & 6 July84 \\
\hline $\begin{array}{l}\text { rand Russ } \\
\text { Gov.--- }\end{array}$ & & 20 & 20 & $25 \frac{1}{2} x$ & $\begin{array}{ll}\times 26 \\
\times\end{array}$ & & & & & & & & & & \\
\hline $\begin{array}{l}\text { Goov.--ex } \\
\text { Grand Trun }\end{array}$ & $12,000,000$ & 20 & 20 & 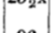 & $x<0$ & $24 \frac{1}{2}$ & 20 & $20 \frac{1}{4}$ & 60 & 027 & 24 & 5"Jan. 83 & G:July83 & 5"Jan.84 & 10July84 \\
\hline $\begin{array}{l}\text { Lake Erie } 5 \% \text { lst Mortgag } \\
\text { Grand Trunk of Canada-Atl }\end{array}$ & $\cdots$ & 100 & 100 & 96 & 97 & 94 & 95 & 951 & $\cdots$ & $\cdots$ & $\cdots$ & $\cdots$ & $\cdots$ & 然 & $\ldots$ \\
\hline St La & 1,127 & 100 & 100 & 133 & 134 & 132 & 133 & 133 & 410 & $s \mid 137$ & 132 & & & & \\
\hline onds. & 466,158 & & 100 & 123 & 124 & 122 & 123 & $1233^{8}$ & 410 & $\begin{array}{ll}6 & 125\end{array}$ & 120 & & & & \\
\hline $\begin{array}{l}\text { Do Buff } \\
\text { Do Chic }\end{array}$ & 525,135 & 10 & 10 & $11 \frac{1}{2}$ & $11 \frac{1}{4}$ & $11 \frac{1}{4}$ & $11 \frac{1}{2}$ & $11 \frac{3}{8}$ & 411 & $s \mid 11 \frac{3}{4}$ & 11 & $5+$ Ang 82 & $5 \frac{1}{4} \mathrm{Feb} .83$ & & \\
\hline $\begin{array}{l}\text { Do Chic } \\
\text { lst M }\end{array}$ & & & & & 110 & & & & & & & & & & \\
\hline & & $\ldots$ & 100 & 99 & 101 & 98 & 100 & $99 \frac{2}{8}$ & 50 & 0105 & 97 & & & & \\
\hline & & & 100 & 93 & $\begin{array}{r}94 \\
115\end{array}$ & 92 & 93 & $93 \frac{3}{4}$ & 57 & d. 97 & 92 & & & & \\
\hline enture stc & & $\ldots$ & 100 & 114 & 115 & 113 & $114 \frac{1}{2}$ & $114 \frac{1}{2}$ & & 5118 & 110 & 5 Jan 83 & 5 July83 & & \\
\hline $\mathrm{D}$ & & $\ldots$ & 100 & 90 & 92 & 89 & $91^{\circ}$ & $91 \frac{\pi}{4}$ & 49 & 095 & 87 & & & & \\
\hline & & & 100 & 122 & 123 & 121 & 122 & 121 & $\begin{array}{lll}5 & 0\end{array}$ & $0 \mid 124$ & 118 & i. $83 \mid \mathrm{f}$ & 6 July83 & & \\
\hline & & & 100 & $78 \frac{1}{2}$ & $82 \frac{1}{2}$ & 78 & $81 \frac{1}{2}$ & $81 \frac{7}{8}$ & & & & & & & \\
\hline & & & 100 & $88_{2}^{1}$ & 89 & 82 & 86 & 86 & 517 & $\mathcal{S} 105$ & $71 \frac{1}{2}$ & & & & \\
\hline & & & 100 & 60 & $62 \pm$ & 554 & $60 \frac{1}{2}$ & 61 & 88 & c) 891 | & $499^{5}$ & & & & \\
\hline 3 on ord. & $7,168,055$ & $\cdots$ & 100 & $27 \frac{3}{4}$ & $28 i$ & 25 & $2 \pi$ & $27 \frac{1}{2}$ & nil. & $45 \frac{1}{2}$ & 22 & 0 Dec. 82 & $3 \frac{1}{2} \operatorname{Mar} 83$ & $\begin{array}{lll}0 & 0 \text { ct. } 83\end{array}$ & 3łApl.84 \\
\hline $5 \%$ & & & 100 & 113 & 115 & 111 & 114 & $113 \frac{1}{4}$ & & 9117 & 111 & & & & \\
\hline & 991,500 & 100 & 100 & 107 & 108 & 106 & 107 & $107 \frac{1}{4}$ & 416 & 9110 & 105 & 6 Dec. 82 & 6 Jne. 83 & 6 Dec. 83 & 6 Jne. 84 \\
\hline $\begin{array}{r}\text { DoORDINARY CoYs } \\
(10,000,000 l \text { at } 2\end{array}$ & $13,415,202$ & $\ldots$ & 100 & $10 \frac{1}{4}$ & $11 \frac{1}{2}$ & 10 & 11 & 11 & nil. & $18 \frac{1}{4}$ & $7 \stackrel{9}{\mid}$ & & nil. & nil. & \\
\hline
\end{tabular}

Figure 16: Sample from the Investor's Monthly Manual. 
may be registered in New York, and registered bonds may be exchanged back again into bonds to bearcr. The total mortgage is for $\$ 10,500,000$; of this amount $\$ 2,500,000$ was set aside to retire an equal amount of first mortgage bonds, and the balance has been issued. By the operation of the sinking fund $\$ 87,000$ of the first mortgage bonds has been redeemed; and of the general mortgage bonds $\$ 1,603,333$ has been purchased and cancelled by the Chicago and Grand Trunk Railway Company, and returned to this company in lieu of rental. The total amount of bonds now outstanding is therefore $\$ 8,809.666^{\circ}$, and this constitutes the entire bonded debt of the company. The share capital is $\$ 5,000,000$. Latest price of general mortgage bonds, 114.

The property of the company is leased to the Chicago and Eastern Illinois Railroad, the Wabash, St. Louis, and Pacific Railroad, the Chicago and Grand Trunk Railroad, the Louisville, New Albany, and Chicago Railroad, the Chicago and Atlantic Railroad, and the Belt Railroad companies. The amount applicable to interest under the existing leases and specially assigned to it is, at present, $\$ 661,000$ per annum. Bach company engages to pay direct to the trustces for the bondholders monthly its specified proportion of this amount, which is to be applied by them first to the interest service of the bonds outstanding, amounting to $\$ 528,000$. In addition to the rental applicable to interest, the leases provide for the creation of a sinking fund, commeneing on July 1, 1884 .

Chlcago, Burlington, and Quincy Rallroad Company.-Office: Chicago, U.S.-Five per cent. sinking fund bonds of this company are quoted in the official list. Some of them were issued here by Messrs. Morton, Rose, and Co., Bartholomew House, E.C., at £179 per bond of $\$ 1,000$. The amount outstanding (of an original issue of $\$ 2,500,000$ ) is $\$ 2,325,000$; coupons are payable April 1 and October 1, and the bonds are to be paid off by October 1, 1901 , all payments being made in Boston. The issue is specially secured by $\$ 2,500,000 \mathrm{St}$. Louis, Rock Island, and Chicago Railroad Company 7 per cent. first mortgage bonds, deposited with the New England Trust Company of Boston, as trustees. The last-named road (270 miles in length) has been leased to the Chicago, Burlington, and Quincy Railroad Company for twenty-five years, with renewals, the Chicago, Burlington, and Quincy Railroad Company agreeing to pay $\$ 175,000$ per annum rental, reserving from this sufficient to pay interest on this issue of 5 per cents., and paying the balance of $\$ 50,000$ and accruing interest to the New Bngland Trust Company, which contracts to spply it as a sinking fund and to buy bonds of this issue semi-annually at or under par and interest. Latest price, 110.

The Chicago, Burlington, and Quincy Company has a share capital of $\$ \mathbf{\$ 6}, 384,525$, and a funded debt, amounting on December 31,1885 , to $\$ 70,913,507$. The accounts are made up annually to December 31 . After payment of 8 per cent. dividends for 1885 there was a surplus on working of $\$ 504,654$, a credit to income account being thereby increased to $\$ 12,367,370$. The share dividends are paid quarterly, and the above rate was also paid in September, 1886.

Chicago, Milwaukee, and st. Paul Railway Company.-Financial Office: New York. - Under its present title the company dates from February 11, 1874. The accounts are made up annually to December 31, and dividends are paid in April and October. For 1881, 1882 , and 1883 the dividend on the common shares was 7 per cent. each year, and for 1884 and 1885, 5. After payment of the dividends for the year there was a surplus on the working of 1885 of $\$ 1,786,020$, making the balance at credit of income account $\$ 6,276,502$. For the first half of 1886 the ordinary shares got $2 \frac{1}{2}$ per cent. The total funded debt on December 31,1885 , was $\$ 101,470,000$. The issues known here are as follow, all of them being to some extent quoted in the official list. Messrs. Morton, Rose, and Co. pay the interest on the sterling bonds of the St. Paul first mortgage, but all other payments are made in New York :-

$\$ 30,904,261$ Common shares of $\$ 100$. Latest price, $97 \frac{1}{2}$.

$\$ 21,540,900$ Preference shares of $\$ 100$, ranking for 7 per cent. dividends, non-accumulative, and participating equally with the common shares in surplus profits after payment of 7 per cent. on both classes. Latest price, 126 .

$\$ 3,804,500$ First mortgage bonds, St. Paul (or River) division. Of this amount $\$ 812,500$ is in sterling bonds of $£ 100$ each. These latter were issued here in April, 1872 , at 90 per cent. net. Interest at the rate of 7 per cent. is payable January 1 and July 1 , and the bonds are redeemable January 1,1902 . Holders may convert into gold dollar bonds or the company's preferred shares. The amount of the sterling bonds was originally 2800,000 . The sterling bonds only are quoted in the official list. Latest price, 132.

$\$ 5,680,000$ First mortgage, Hastings and Dakota division, 7 per cent. interest payable January 1 and July 1 , and redeemable January 1, 1910. The bonds are of $\$ 1,000$. Latest price, 130 .

$\$ 4,000,000$ First mortgage, South-Western division, with 6 per cent. interest payable January 1 and July 1, and redeemable July 1, 1909. The bonds are of $\$ 1,000$. Some of them were sold here in April, 1880. Latest price, 123.

Figure 17: Sample from the Stock Exchange Yearbook of 1887. 
A typical IMM entry included:

- Name of the security. This contains the name of the company or country that issued the security, type of security (debenture, stock, preferred, deferred or common share, guarantees, and if it was based on a mortgage) and additional information such as coupon rate, issuance price or year of redemption (maturity). ${ }^{67}$

- Number of shares or amount of stock. This column contains the number of shares in the case of stocks or the total amount of the monetary value of bond issues (face value of each bond times the number of bonds issued). In the case of railway companies, this column was named "Capital Subscribed" and for most of the period contained a pound sign (and dollar signs for specific securities denominated in dollars). For sovereign bonds, the column name was "Amount of Loan Unredeemed". The section for sovereign bonds also contained another column called "Original Issue". The difference between "Original Issue" and “Amount Unredeemed" was usually the result of sinking funds (a mechanism of gradual redemption of the issue - explained in detail in footnote 30). In this paper, the variable amount of stock is usually called total capital.

- Capital share or stock. The indivisible nominal/face value of one share or the capital amount divided by the number of shares. When the security is a stock, the word "Stock" replaces numbers in the IMM. The typical share for bonds was 200

\footnotetext{
${ }^{67}$ In the case of railways, the majority of bonds were described as mortgages, since real assets (lands, rolling stock) backed them.
} 
pounds or 1000 dollars. This column is absent in the section for sovereign bonds.

- "Paid" or par value. A company could issue a bond or a stock at a certain price but only demand that the investor pay upfront a percentage of the total price (for example 50\%). At any time in the future, the shareholders could be called to pay the difference. The expression used at the time was "capital call". This was an incipient mechanism of contingent capital. When a new security was issued, the expression used was "capital created" and could include the whole amount of the issue, even the part that was not called yet.

Prices of the month. These are market quotations for the price of the security. There are four columns: opening (price of the first day of the month), highest (highest price reached during the month), lowest (lowest price reached during the month), and latest (closing price of the month). The "last business done" column indicates the quotation of the last trade of the previous month if the security was not traded during the current month. The price quotation is usually "per cent", meaning the price an investor would pay to acquire an equivalent of 100 pounds (or 500 dollars) of the nominal value of the security, even if the capital share was higher. In this sense, most of the prices at the LSE were quoted around the value 100 and it was easy to distinguish between a security that was trading below par and above par. The exceptions referred to securities (usually equity) with share value below 100 (for example GBP 10 or GBP 50). In this case, the quotation was per share and the price was around the nominal value of the share. ${ }^{68,69}$

\footnotetext{
${ }^{68}$ The interval of the price variation is a reasonable indicator for the amount being negotiated, but during episodes of interest default prices could sink, taking away the usefulness of the indicator. The
} 
- Last four dividends paid. This section represented the coupon or dividend payments. Several formats for the presentation were used over the years. In earlier years, the format took advantage of the fact that the coupon rate was included in the name of the security and simply stated the months or frequency of payments of the dividends, such as "Feb\&Aug" or "hy" referring to semi-annual payments and "qa" for quarterly payments. Later, the format evolved to include the actual payment and the date of payments, probably due to the fact that effective payments were often different from the coupon rate. This was represented by four numbers and four dates ("6 666 Jan94 Aug94 Jan95 Aug95"). The actual payment was generally given by a percentage of the nominal value, but there were cases of dividends presented in terms of pounds, shillings and pence. ${ }^{70}$ Most importantly, this section also indicates periods when coupons were not paid. In this case, it is possible to note frozen dates for an extended period. Besides that, sometimes the word "nil" would be included in the date when a payment was supposed to happen. If the lack of payments covered an extended period, a simple expression "nil since" was included along the date of the last payment. When payments resumed, the period without payment became "nil between".

\section{- Last year dividend yields Investor at Latest Price Percent. Total dividend}

\footnotetext{
"usual" price level is important information for aggregations of data, since it determines the right factor to weight the prices of securities. The Railway Times is a useful crosscheck for this information with respect to railroads securities.

${ }^{69}$ The IMM usually reported accurate issuance prices. When the issuance price was included in the name of the security, the manual would just indicate the premium over the indicated price with "p" or "pm" next to it ("d" was used for a discount). Large returns would be found if the premium is mistakenly used in the place of the price.

${ }^{70}$ ICF created a new column with the values in pounds, shillings and pence converted to total pence values, using the usual conversion of one pound for 20 shilling and 12 pence for one shilling.
} 
yields for the previous ("last") year in pounds, shillings and pence. This column was introduced in June 1879 taking into account the two last dividends. Around 1885 , it started to take into account all the dividends paid in the last year. Until December 1882 , it simply represented the dividends or coupon payments given by the section "Last four dividends paid" (and multiplied by the nominal value) divided by the market price. After January 1883 and with the arrival of a new editor to the IMM, the calculation started to include the expected capital gain between the current market price and the redemption value. This included thousands of calculations of compound interest rates when the redemption date was years ahead of the current date.

- The sovereign bonds section was slightly different from the other sections. The columns "Original issue" and "Amount of Loan Unredeemed" were already explained above. It also contained a separate "Issue Price" column (in other sections, this information would be included in the name of securities). Three columns were dedicated to sinking funds: how much of the original issue was redeemed every year (usually 1\%), the months when it was applied and the final year of redemption. The last information is particularly useful with respect to the calculation of maturities of bonds. Since several schemes for sinking funds existed at the time, these columns are permeated by non- standard entries such as the one for British securities: "Difference between annual interest and 25,000,000 pounds applied to purchases, and surplus income for year applied to purchases in succeeding years."

- Other information such as highest and lowest prices during the last year and, in 
some editions (June and December), specific notes about the country of the company or government could also be included.

The IMM varied the way it presented the data over the period. Securities were normally organized by purpose, for example with sovereign bonds in one section and company bonds in another; railway companies usually had their own section. Other important sections were "mining" and "banks and financial companies". The rest of the companies, including utilities, were included in the category "miscellaneous". The sections changed over the years, reflecting the increasing complexity of the market. The section for railway companies was split by country (or region) in 1895, after which there were specific sections for British railways, American railways, Colonial railways ex-India and Indian railways. These sections make the assessment of the country of origin for each security straightforward for the later periods. Before that, the identification relies on the name of the security. In the case of sovereign bonds, identification is straightforward. ${ }^{71}$ The names of securities of railway companies,

\footnotetext{
${ }^{71}$ The classification could change according to political developments. The regions of Australia (example: Tanzania) and Canada (example: British Columbia) were considered autonomous entities before the formal creation of federations. They were classified as Australian and Canadian nonetheless (Newfoundland was considered as Canadian despite the fact that it joined the federation much later). A single Confederate bond (guarantee by cotton) was classified as American. Boer's colonies such as Orange Free State and Transvaal were autonomous countries in the beginning of the sample and later became part of the Union of South Africa, a colony of Britain. Their securities were classified under Britain in the last issues of the IMM but I opted to classify them as South African in the database. I also classified Prussian and North German Confederation's securities as German. For a variety of reasons, the government of Britain issued guarantees for sovereign bonds of other countries, usually but not necessarily protectorates or dominions. As in the case of South Africa, they were initially inserted under the country that issued them but later they were moved to the British space and a note under the country's space stated "See Britain". We classified those securities according to nationality and not the guarantee. A case of a non-colony security with a British (and French) guarantee is the Turkish $4 \% 1855$ bond.
} 
subnational debt and utilities companies are usually linked to their place of origin.

The SEY was extensively used to clarify the countries of some companies. ${ }^{72}$

The IMM contained other sections besides the tables with financial information described above. In some editions there was a "Tabular History of the Money" with the history of changes in the discount rates from the Bank of England. The editors of the journal analyzed companies and the general state of the market in the first section. The last section was dedicated to notices and reports from companies. A table of "Home Railway Traffic Returns" listed the revenues and other operational statistics from the most important railway companies in each continent. More important was another table by the name of "British Capital Created and Called". This table contained information on new issues of securities, including how much of each security was already paid and if the company was calling for more capital. There was a subsection of securities that were "subscribed partly abroad", meaning that part of the capital stated was raised in other countries in spite of the fact that the table states the total amount of the capital subscription.

\section{$\underline{\text { Data Cleaning }}$}

There are several issues with respect to the identification of securities. The ICF file provides codes for each security but securities are not always tracked correctly for several reasons. ${ }^{73}$ This problem is particularly severe for large

\footnotetext{
${ }^{72}$ Some railway companies are listed as American but their business is performed in other countries. This is the case of some Mexican railway companies and the Panama railway company. The last provided the link between the Atlantic and Pacific oceans before the construction of the canal.

${ }^{73} \mathrm{ICF}$ is still working on the identification codes. A table with all the modifications made to the original series is available upon request.
} 
companies that issued several securities simultaneously. Unfortunately, the names of the securities are not always reliable. In order to save printing space, the IMM only stated the name of the company for the first security listed. All the following securities for that same company list "do" (from ditto) to indicate that the name of the company is the same as the one of the security listed above. This is also true for securities that share some kind of characteristic, such as coupon rates. The first entry states the characteristic and subsequent entries use the word " $d o$ ", listing only the security's distinct characteristic (for example, a different maturity). The ICF reproduces for each of the following securities the whole name of the first security, and the additional information is listed in a different column called "Security Description”. Other issues that make it difficult to identify securities include:

- Names of securities given in the IMM change over time, usually with the addition of more information, such as year of maturity, coupon rate, issuance price, guarantees provided by other companies, and the existence of a gold or sterling clause. The basic information is the type of security (if it is a stock, bond, preferred share, ordinary share or mortgage). ${ }^{74}$

- $\quad$ Large companies actively managed liabilities. In several cases, companies redeemed securities before their original maturity and switched them for securities with lower yields or longer maturities. Companies also merged securities or created new securities by splitting others.

- $\quad$ New companies were created and existing companies failed and were bought by

\footnotetext{
${ }^{74}$ During the analyzed period, the editors of the IMM made efforts to homogenize the names of the securities, including coupon rates and including a new column with the year of redemption of the securities.
} 
other investors. Mergers and acquisitions were especially common for railways, since, for example, local railways were combined to cover larger geographic areas. All those processes implied name changes. ${ }^{75}$ Companies also issued securities for spin-offs. For instance, a company might issue separate series of securities for a specific project, such as a tunnel, bridge or even a certain extension of the railway to a city or region.

- The original IMM contained typos. Most were minor but in some cases two securities switched places from one month to another. In other cases, the figure in the total capital column could be the sum of multiple securities linked by brackets. To assign the whole amount to only one security or to repeat the same value for all securities inside the brackets would not be accurate. ${ }^{76}$

The identification of each security was the first step in cleaning and organizing the data. Using the capital column, which tends to be less volatile, each security name was tracked for intervals of five years using the IMM issues. ${ }^{77}$ For each security, if any information was added throughout the years, the name was modified only to the extent that the new information did not represent a drastic departure from

\footnotetext{
${ }^{75}$ For example, the Erie Company changed its name to New York, Lake Erie and Western company around 1879. In 1896, it became Erie Railroad again. While such name changes could have been associated with a change of management, the fact is that some securities survived the transitions. In some cases, the old securities with the new company name were wrongly listed as new securities.

${ }^{76}$ The technical appendix lists the procedures used to distinguish between some of these securities.

${ }^{77}$ These intervals ended in December of 1869, 1875, 1880, 1885, 1890, 1895, 1900, 1905, 1910 and June of 1914. If a security was not identified through those intervals (in the case of securities with a life shorter than 5 years falling between the thresholds), a month and year inside the interval of the life of the security was verified. It is necessary to attest that at some point in time the security existed alongside others, which excludes the possibility of classification of a security with a new name as a new security. Besides the SEY, supplementary sources such as Railway Times, The Banker's Magazine and Statistical Register, Moody's Manual of Corporation Securities, Commercial and Financial Chronicle, The Economist and annual reports from companies were used to check information not clear in the original data.
} 
the former name. If that was the case, a note was included and further investigation conducted.

Once each security was uniquely identified, time series were scanned for further problems. Most of the time, a note indicating a sudden change of name led to the conclusion of an inappropriate joining of two securities. Similarly, two securities with similar names are in most cases one security at different points in time. While the capital column was the starting point to identification, all information present in the other columns was used to check identification of securities (for example two securities with the same amount of capital and name would not be joined if this would imply in a sudden jump in prices). Also, caution was taken not to modify security movements that are the consequence of regular corporate finance operations, such as the exchange of one security for another or the merger and split of securities.

I use the following procedures to deal with gaps in the data. For the variable "total capital," gaps smaller than six months were linearly interpolated. This length avoids filling in observations that represent genuine breaks in the series but covers most cases of data missing in the original document. For the variable "price," the first step was to impute missing observations with values from "Last Business Done" ${ }^{78}$ After that, I filled the remaining gaps by linear interpolation independently of the length of the gap. I did not use extrapolation: gaps in the beginning or end of the series remained blank. For par value and capital share, simple linear interpolation was used.

\footnotetext{
${ }^{78}$ It is possible that intervals when prices are not quoted (prices are a blank space) represent periods of failure or restructuring of companies. This will be crosschecked in the future with the available list of defaults.
} 


\section{Variables Created}

The database includes new variables that facilitate the handling of information. These variables convey useful information (usually contained in the name of the security) to classify and summarize the data.

The variable Return contains the coupon rates of bond and preferred stocks. For some securities, the coupon rate decreased or increased over time. In those cases, the last coupon rate was registered in Return and the initial coupon rate was registered in the variable ReturnInitial. ${ }^{79}$

The variable FactorShare describes the factor by which prices should be divided in order to represent a "per cent" quotation, meaning the price an investor would pay to acquire an equivalent of 100 pounds (or 500 dollars) of the nominal value of the security. Since most prices quoted at the IMM already followed the "per cent" convention, the mode for this variable is 1 . Nonetheless, the variable is an important tool to correctly aggregate securities.

The variable Issued represents the issuance price when available and YearRed the year of redemption when available. Country is a three-letter code for the country of origin of the company or government that issued the security ${ }^{80}$ Type lists the sector of the security ("RR" for railways and "GOV" for sovereign - other sectors will be added).

\footnotetext{
${ }^{79}$ The ideal procedure would be to create time series of coupon rates for each security, but for simplicity I decided to adopt a cross-section classification. Nonetheless, there were only few cases of securities with varying coupon rates.

${ }^{80}$ Another variable (CountryName) containing the whole name of the country was utilized for government securities in order to include the name of the country in the name of the security. For example, "5\% 1878" became "Brazil 5\% 1878".
} 
Dummy variables assume only two values: zero or one. Six dummy variables were created: Stk, Pref, Curr, Sterling, Gold and JointK. Stk assumes value 1 when the security is equity (and zero if it is debt). Given that $S t k$ is 1 , Pref assumes value 1 if the share is preferred (and zero if it is common). Curr assumes value 1 if the capital of the security is not quoted in pounds. For railways, the great majority of cases refer to dollar securities. ${ }^{81}$ The symbol of identification of the security's currency is specified as a comment to the security. ${ }^{82}$

When Curr is one, Sterling and Gold assume value one in the presence of a sterling or gold clause. When the security has a gold or sterling clause, coupon payments are fixed in pounds and the investor is not exposed to exchange rate risk. As with emerging markets' sovereign debt in the twentieth century, this clause signaled investors' low trust in the currency. A dollar-denominated security with a sterling clause is identical to a security quoted in pounds (but dependent on the promise of the company).

Joint $K$ assumes value one if the security's capital is quoted jointly with another security (see the last point of the section Data Cleaning). If that is the case, a

\footnotetext{
${ }^{81}$ After the segregation of the section for American railways in 1895, the currency sign was explicitly listed, which facilitated the identification of the currency. Before that year, only securities with capital not quoted in pound sterling included the currency symbol. The IMM switched the currency of quotation of few securities for no apparent reason. The mistaken interpretation of a currency switch could lead to the calculation of large capital gains. The switches were identified by large movements in all prices (last, low and high) from one month to another. In the case of an American security for example, prices could jump from 100 (pounds) to 500 (dollars). All the cases were identified and corrected. The usual splicing technique was to convert the second part of the prices series to the currency of the first part according to the exchange rate of 5 dollars per pound.

${ }^{82}$ The following symbols were identified for sovereign bonds: Krona (Denmark), Fl (Netherlands), Mark (Germany), Kr (Austria-Hungary), Lire (Italy), Yen (Japan), Fcs (Rumania), Ruble (Russia), Peseta (Spain) and Francs (Switzerland). Some securities from India, Argentina and France almost surely were quoted in their national currencies. In the case of railways, besides the pervasive presence of the American dollar, some securities from other countries also carried the dollar sign. In the case of Chile for example it could mean Chilean dollars.
} 
comment is added to the security in order to identify the other security that shares the same value of capital. As is the case with the variable Return, it is possible that two securities only share the capital value for a limited period, assuming independent capital values afterwards. A comment is also included if that is the case, although the variable JointK is not a time series. It simply indicates that the security shared the capital value with another security at some point in time. Other relevant commentaries for each security are also included in the database.

\section{Dividends}

The IMM's dividends section is the least tractable part of the publication. An algorithm was created to extract all the information available from the several columns representing dividend payments. Dividends were contained in at least four columns, corresponding to the last four payments. In the algorithm, each operation is repeated four times and the outcome of each column can be verified with the other

three, since they represent the same time series with lags. ${ }^{83}$ A basic description of the procedure follows:

- The database was cleaned in order to eliminate typos and non-standard entries.

All dates were converted to a standard format.

- Dividends given in pence were converted to values representing the percentage of the capital considered as minimum amount (100 pounds or 500 dollars if the

\footnotetext{
${ }^{83}$ An example clarifies the procedure: If the column for the second to last payment of a security in the month of March 1897 contains an entry such as Jun1896 and payments of dividends are made two times a year in June and December, the Jun1896 entry would be in the column for the last payment until December 1896 (or January 1897 if there is a lag). In the case of this security, the column corresponding to the second to last payment is identical to the column of the last payment with a lag of six months and excluding the last dividend payment. The same is true for the third to the last payment and the fourth to the last payment.
} 
capital share or stock was above this value or the capital share or stock if it was below 100 pounds). The values in pence could be located in specific columns ("Dividends Last Four Pence"). If the values in pence were instead in the column “Dividends Last Four Rate Percent per Annum", they would be accompanied by the symbols " $\$$ " and " $£$ " or the words "cash" and "currency" would also be in the same entry. When dividends were written in the $\mathrm{p} / \mathrm{s} / \mathrm{d}$ format (pounds/shillings/pence), it was checked that they were also available in pence format, by using the conversion rate of 20 shillings per pound and 12 pence per shilling.

- When figures for dividends were available from the columns "Dividends Last Four Rate Percent per Annum" but months were in the format "Jun;Dec" or "Jan;Apr;Jul;Oct", it was considered that the payments were made according to those months, meaning that a payment was assigned to each month. Since there were four entries at each point in time, it was considered that the stream of payments was changed when a month arrived. For example: "Jan;Apr;Jul;Oct" was interpreted as “January/1900, April/1900, July/1900, October/1900” from October 1900 to December 1900. In January 1901, the stream would change to “April/1900, July/1900, October/1900, January/1901”. When the words "nil” or "deferred" appeared, no payment was assigned. A blank space in the column "Yield Investor at Latest Price" after May 1879 (the year the IMM started publishing these figures) was also considered as evidence of lack of payment.

- When figures for dividends were not available, the coupon rate contained in the name of the security was used, using the same procedure described above. This 
was possible for debt instruments and preferred shares.

- Other information contained in the dividend field was transformed to standard

format when it was possible to interpret it. For example "dividends from Oct 1904 paid in Dec 1906" were interpreted as a payment in December $1906{ }^{84}$

- The final step was to convert the dates and values represented in several columns into one series containing the coupon payments. A security with an entry like "6 6 66 Jan84 Aug94 Jan95 Aug95" would have entries of 6 in each of the months listed in the entry. This new series was called dividends. Duplicated entries were excluded.

- In order to aggregate and smooth series, dividend payments were averaged by year and the average was assigned to each month of the year. In calculating the average, I took in consideration the number of dividend payments per year (for example: two or four), since the IMM figures were already annualized.

\footnotetext{
${ }^{84}$ IMM seems to adopt the principle of assigning dividends to when they were $d u e$ and not to when they were paid. If a company pays dividends twice a year in the months of June and December and for some reason the payment of the second dividend happens in January, the IMM would in theory describe that payment as "December". The rule is not always followed. Some companies missed payments for many years, and it is highly unlikely that the original schedule of payments was followed after resumption of payments (those payments were probably never recovered by investors). In many cases, the original schedule was changed after some delays (for example "June and December" becomes "August and February" after a June payment was delayed until August). The problem of distinction between the two concepts was aggravated by ICF compilers' different interpretations of non-standard entries. For parsimony, I adopted the principle of assigning the payment to the date when it was made.
} 


\section{Chapter 6: Conclusions}

The main contributions of this work are threefold. By constructing estimates of the British net external position, as well as capital gains and dividend yields on the British net external position, I determined that Britain received a significant aggregate exorbitant privilege. The average net revenues of $13.4 \%$ of GDP over the period 1869-1914 represented an important part of Britain's economic structure. The country satisfied the necessary condition for the existence of an exorbitant privilege for most of the period.

The study also introduces another global reserve currency, the pound sterling, and brings another observation to the exorbitant privilege literature in the period 1870-1914. This important period is comparable in terms of integration of financial markets to the last quarter of the twentieth century. Since there was only one global reserve currency observation (the US dollar for the second half of the twentieth century) before this dissertation, every feature of the particular US case was associated with the general exorbitant privilege phenomenon. With the analysis of another global reserve currency, it is possible to isolate the idiosyncrasies of the US case. One example is the severance of the link between being a debtor country and enjoying exorbitant privilege.

The final main contribution is the new dataset encompassing almost $90 \%$ of the value of securities traded at the London Stock Exchange. The original source of the data has been used in the economic history literature, but I apply it in a novel way to build the net external asset position of Britain. The methodology presented here to transform the data into significant macroeconomic variables is an independent 
contribution that could be applied to other countries, including the modern United States.

Future steps with respect to the data are:

- Incorporation of remaining sectors. Although they represent only $12 \%$ of the value of securities traded at the LSE, some might bring additional insights to economic aspects of the period. Examples are commodities, industry, banks and local and municipal governments. Nonetheless, the main results should remain intact when the whole sample is incorporated.

- Refinements of the data and the assumptions. The incorporation of particularities of the period such as sinking funds and par values might increase the quality of the estimation of exorbitant privilege. A more comprehensive understanding of the conventions adopted by the IMM and an exhaustive analysis of the units of dividends and currency of securities would also improve measurement.

- A continuing effort to find and fix errors in the securities in the database.

- Evidence with respect to other British foreign investments besides portfolio, such as direct investment and bank loans.

A theoretical explanation of exorbitant privilege was beyond the scope of this work. Some of the sections try to assess preliminarily hypotheses with respect to the origins of the return differential. The most important controls I can think of, besides inflation, are default and devaluation risks, volatility and maturity. The inclusion of those factors can also be an important step in the direction of developing a more theoretically based measure of exorbitant privilege. A serious treatment of risk is the most pressing issue. The original literature indicates that the benefits enjoyed by the 
issuer of the global reserve currency derive in part from the perception that it is the safe asset. One of the many achievements of the literature on Britain's export of capital before WWI is the assessment of the mean-variance frontier of British external investments. This assessment could be readily applied to the US in the last quarter of the twentieth century if more disaggregated data on the securities that compose the US net external position become available to researchers. In this sense, an analysis of the role of the US as a global hedge fund or as a global insurance company is contingent on an accurate picture of the transformation of risk facilitated by the US external position. National statistical compilers should start publishing information on the risk of the components of countries' external assets and liabilities. The methodology of this paper can be directly applied to American microeconomic data in order to confirm or refute the results based on aggregate data from the international finance literature.

One important topic for future work is the analysis of the ascension of the dollar as the global reserve currency. In many of the charts presented in chapters 3, 4 and in the appendix on American Railroads a clear pattern arises: all the dollar related series suffer a structural break around 1895. A big share of the increment on British revenues in this period derives from a sudden increase of the market value of American securities in comparison to their issuance prices. It is possible that this break represents a shift in expectations with respect to devaluation risks. Markets for currency futures did not exist, but it might be possible to identify expectations of currency devaluations by using gold reserves variation as proxy. The devaluation risk 
can be disentangled from default risk by comparing movements in the prices of government and railroad securities.

Similarly to the US in the last quarter of the twentieth century, the main part of Britain's excess returns derived from British external assets receiving higher returns than were paid on external liabilities for each class of asset. On the other hand, the British invested mostly in debt, a type of security with low returns and low risk. Different from the US, Britain's international investment position did not resemble the one from an investment bank, short in safe assets and long in risky assets. The lack of a composition effect (less risky assets than liabilities) was a handicap to Britain in relation to the US when comparing total returns.

The low total excess return on its net external position meant that the exceptional revenues received by Britain from the rest of the world were more a consequence of the sheer size of its net creditor position, which reached around 180\% of GDP on the eve of the First World War. For most of the period analyzed and given the returns calculated above, Britain would not have received positive revenues from the rest of the word if it were a net debtor country. After 1900, returns (mostly derived from securities in other currencies) increased, which meant that Britain would have been able to become a debtor country while still receiving positive net revenues from the rest of the world. The First World War probably interrupted this process.

The results are interesting not only for Britain but also for the US, since they allow the parsing out of the differences between two issuers of the global reserve currency. At least partially, the United States currently enjoys an exorbitant privilege because it is the issuer of the global reserve currency and not because it possesses 
some other unique characteristic. This means that any country that is in the unique position of issuing the global reserve currency in the future will enjoy similar benefits in terms of investors demanding lower returns to hold its securities.

The analysis reveals the existence of different responses to the advantage presented by an exorbitant privilege, instead of taking as given the particular features of the American case. Britain was an exporter of capital, continuously increasing its gross asset position. Britain leveraged the benefit from exorbitant privilege in proportion to the size of its external assets. Since Britain invested mostly in safe assets (debt), the leveraging of a small returns differential by a large positive stock position was a fundamental component of the aggregate benefit. In the jargon of this dissertation, Britain derived an aggregate exorbitant privilege not from the existence of a significant weighted exorbitant privilege, but from the "grossing up" of a small weighted exorbitant privilege.

On the other hand, the United States would be caught in a bubble equilibrium in the absence of exorbitant privilege ${ }^{85}$ By balancing the current account deficit with revenues arising from the position of the dollar as global reserve currency, the country has gone deeper and deeper into negative territory with respect to its net external position. What seems to be unique with respect to the US is its propensity to invest in risky foreign securities. The distinct profiles of risk between American external assets and liabilities boost the return differential enjoyed by the US. The effect is strong enough to permit the US to be a net debtor country. These dynamics would not be possible without the special position occupied by the dollar in the

\footnotetext{
${ }^{85}$ In the sense of not fulfilling a transversality condition given by the stream of future current account surpluses and the return on the present stock of net external liabilities.
} 
international financial system. These two distinct outcomes for Britain and the US are stylized facts that ought to be incorporated in future theoretical formulations of the problem. The pattern of a creditor country investing in safe assets while a debtor country prefers to invest in securities with a higher profile of risk could be endogenous, and this hypothesis could only be suggested after the completion of this dissertation.

The results of this work are significant and will play an important part in our understanding of the international monetary system, the role of the global reserve currency, the advantages derived by Britain from the centrality of the pound sterling, as well as the dynamics of the modern US. It is also my hope that by exploiting further the dataset and the methodology presented here, the experiences of the past will help to shed light on the complexities of the future. 


\section{Appendices}

\section{$\underline{\text { Al American Railways }}$}

One important subset of the data used in this paper is US railroads. The US was the major destination of British capital during the period of study, receiving $20.5 \%$ of the total British capital called between 1865 and 1914 (Canada was in second place with $10.1 \%$, Stone 1999). The US was the top destination of British capital in all but two five year intervals- 1875-79 and 1885 - 1889 (and in these, it was number two respectively after Australia and Argentina, with only minor differences). Railways received $61.6 \%$ of the British capital destined to America from 1865 to 1914 , followed by industrial \& miscellaneous (10.8\%). In years like 1894, 1902 and 1903, railways received more than $90 \%$ of the British capital destined to the US. The US was the number one destination for British capital invested in railways for all 5-year periods after 1870. Figure 18, which presents the information of the middle panel of Figure 2 (railroads) by class of asset, shows that the US received the largest share of British investment for every railroads class of asset analyzed. 

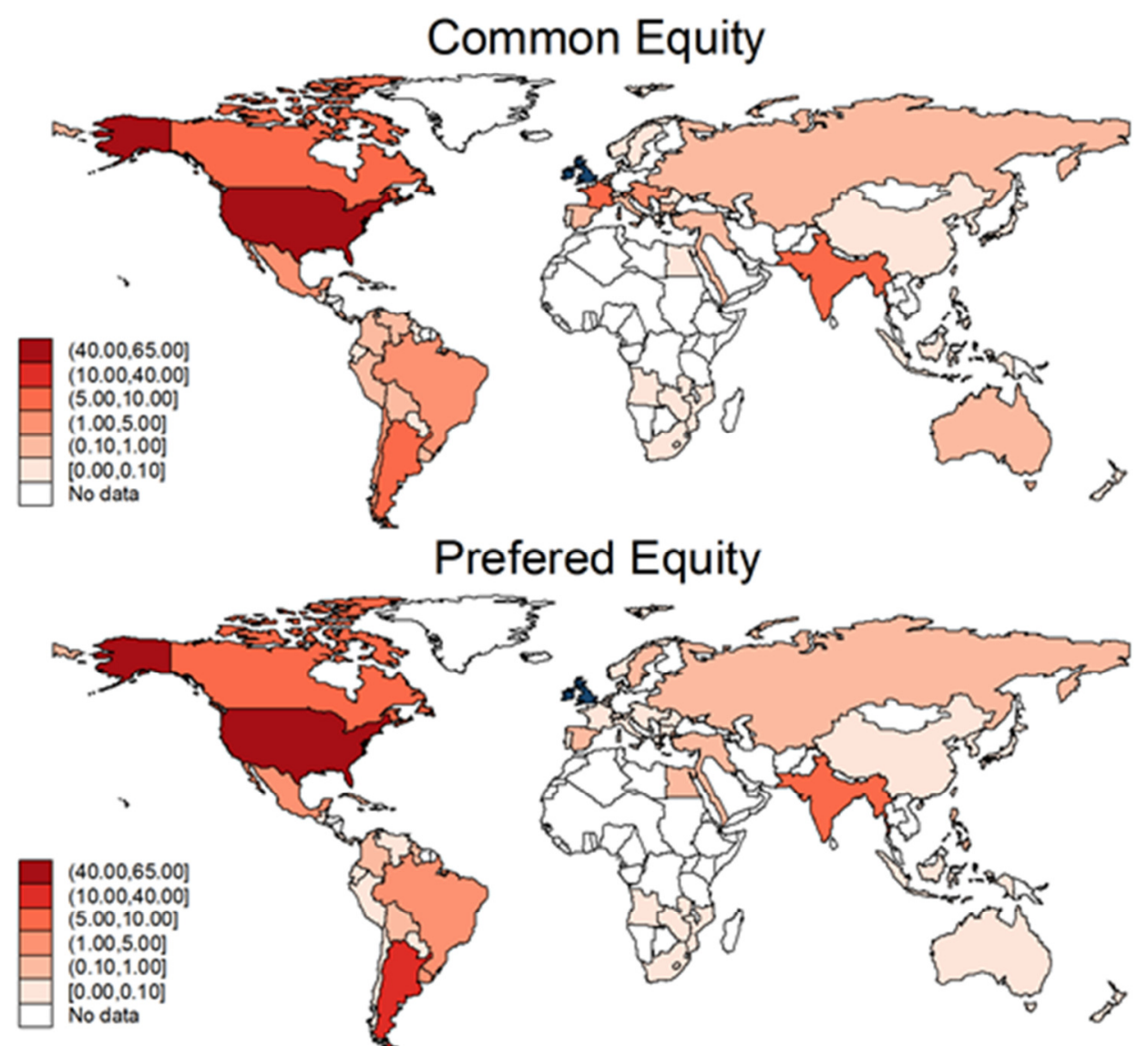

\section{Debt}

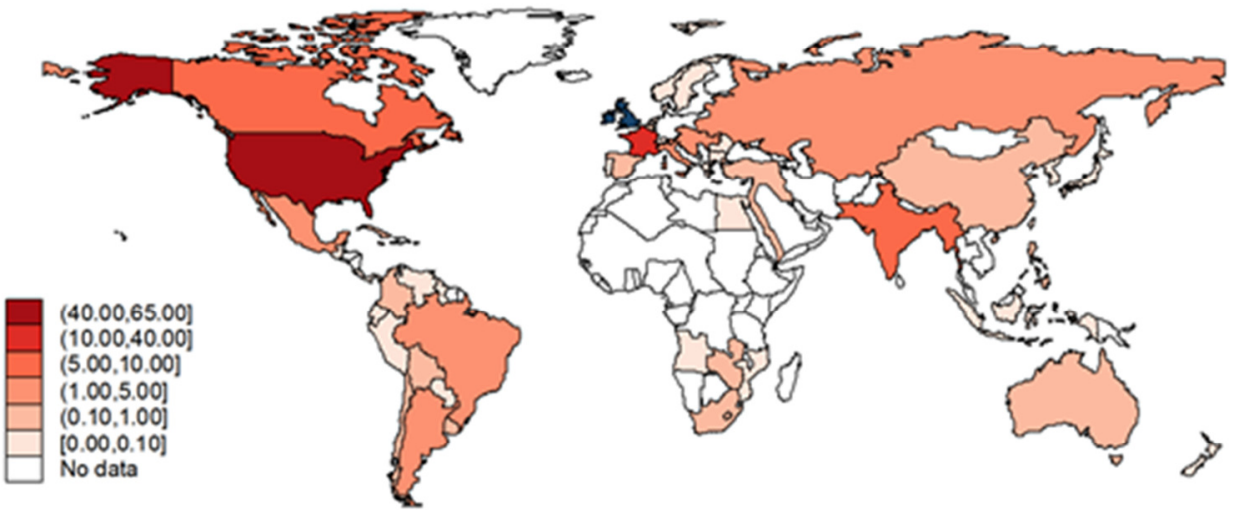

Figure 18: Share of each country in total British railroads investments (1869 - 1914) by class of investment (percentage)

The database contains 574 securities for American railroads, spanning January 1869 to July 1914 (with 87,067 observations for capital and 89,553 observations for 
prices). Based on the uniquely defined names of the securities and the currency in which capital is denominated, I created five groups of securities:

1) Total capital denominated in pound sterling. ${ }^{86}$

2) Total capital denominated in dollars and without any clauses.

3) Total capital denominated in dollars and including a gold clause.

4) Total capital denominated in dollars and including a sterling clause.

5) Common stocks. ${ }^{87}$

The top left panel of Figure 19 shows the number of securities listed by each type in each year. The number of securities denominated in dollars was similar to the number in pounds around 1875 and both remained stable until around 1895, when the number of securities denominated in dollars increased while the number of securities quoted in pounds slowly declined. The number of common stock shares seems to be constant. The major source of dynamics from the panel comes from the rapid expansion of the number of securities quoted in dollars with gold clauses. Between 1880 and 1895 , securities payable in dollars with gold clauses became the most important type being issued by railway companies at the London Stock Exchange. This might be related to the fear that silver would be added to the monetary base of the US at this time. After 1895, a decline occurs in securities with gold clauses, matched by an increase in dollar securities without gold clauses. The subsequent

\footnotetext{
${ }^{86}$ Some securities do not contain currency symbols. In some cases, it was possible to determine the currency by the denomination of the share - the total capital represented the number of shares. The IMM also started quoting some securities in dollars and switched to pounds after some time even if the value of capital did not change, which is clearly a mistake. The confusion may be caused by the fact that securities without symbols were by default in pounds before the creation of a special section for American railways. I attempted to determine the genuine currency of the quotation. See technical appendix for details.

${ }^{87}$ Only one security described as common share was denominated in pounds.
} 
reduction in American shares and dollar securities in London may be due to the ascension of the New York Stock Exchange.

The top right panel shows the total amount of capital for each group in millions of pounds sterling. A slightly different picture arises. A fast expansion of issuance of capital is detected, especially for dollar securities without gold or sterling clauses after $1895 .^{88}$ Until that period, the main form of railway financing was through common stocks (called "dollar stocks" in Figure 19). The value of common stocks and dollar denominated securities with gold clauses also expand after 1905. American railroad firms acquired British capital first by issuing common stock, then by dollar securities with gold clauses and finally by pure dollar securities, with a further expansion in common shares and more dollar denominated securities with gold clauses following 1905. Most types of railway bonds were mortgages backed by real assets and, hence, firms in possession of more land, miles of tracks and rolling stock could issue more debt. By comparing the number of securities (from the first panel) and the value of securities in the second panel, it is possible to conclude that common shares and dollar denominated securities without clauses had on average a higher unitary value. Since the number of securities was not expanding after 1900, this means that the average unitary value of securities was expanding.

\footnotetext{
${ }^{88}$ This may be a consequence of the 1896 US presidential election. Since the main issue of the election was whether the US would stick to gold or switch to bimetallism, the victory of William McKinley (the sound-money candidate favoring gold) against William Jennings Bryan (the populist candidate advocating the coinage of silver in order to generate inflation) may have been seen by international investors as a watershed event confirming the US' commitment to gold. Thanks to Professor John Shea for indicating this. Another possibility is described by Edelstein (1982): "Following considerable financial distress in the 1893 - 96 depression, the financial structures of many U.S. railway companies were radically reorganized and many companies disappeared through consolidation. By 1902, "morganization" had resulted in a much more concentrated industry with 70 percent of the U.S. trackage controlled by eight great railways systems and a shift of external financing arrangements into the hands of a few elite Wall Street firms." Also, "the new industrial giants issued equity and preferred stock in roughly equal amounts with debentures taking a very minor role."
} 
Finally, the two lower panels report the coupon yield for each category, with the exception of common shares. The lower left panel shows unweighted averages and the right-hand panel shows yields weighted by capital. The striking pattern is the reduction in yield for almost every category during this period. Pound securities yields are usually lower than those from pure dollar securities until 1890. Dollar denominated securities with gold or sterling clauses offer the lowest yields for almost the entire period. After 1900 yields on pure dollar and pound securities reach new lows. The presence of gold clauses reduced the yield to British investors for most of the period (making capital cheaper for American firms). At some points in time, the gap could be more than 0.5 percentage point. 


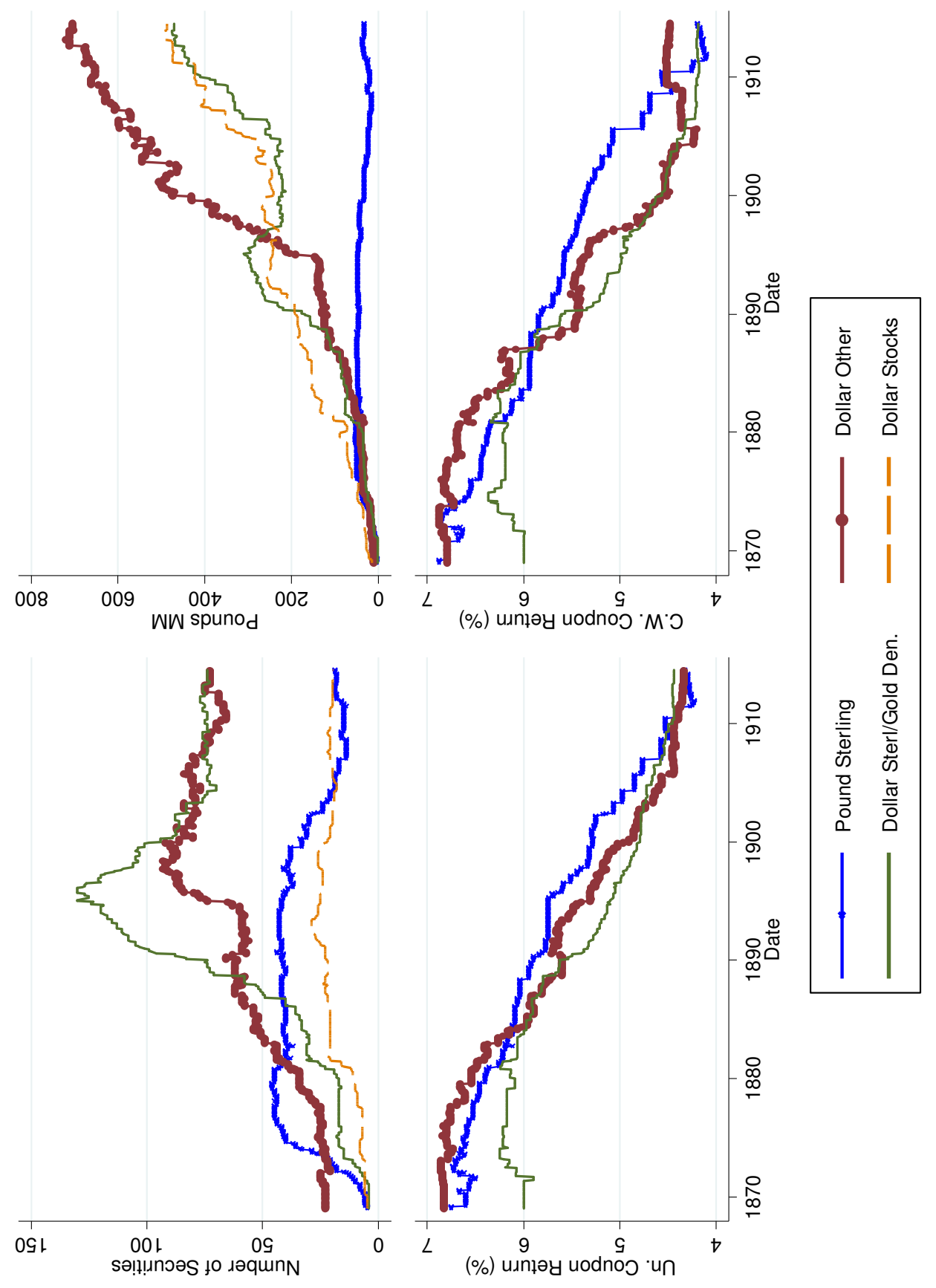

Figure 19: Characteristics of American railroad securities 


\section{A1.1 A New Measure of US External Liabilities before WWI}

Railway securities were the largest British investment in the US. Since Britain was the largest source of available capital, these securities constituted a large share of the US external liabilities for that time. A proxy for the dynamics of US external liabilities can be compiled by using the same techniques presented above for the UK external position.

Figure 20: New series for American International Liabilities. shows US external liabilities in market and issuance prices in millions of pounds sterling (top panel) and as a percentage of US GDP (bottom panel). ${ }^{89}$ Acknowledging that these series include only investment in railroads by British investors, this is the first monthly market value estimate at market prices of the external liabilities of the US for the period 1869-1914. External liabilities in terms of millions of sterling pounds increased steadily for almost the whole period and at a faster rate than GDP from 1869 to 1895 . Both series went from close to zero to around $20 \%$ of GDP by the year 1895. As a share of GDP, the issuance price series stops growing around 1895 and the market price series around 1900. The two series are close until the turn of the twentieth century with the issuance price series slightly above the market price series, which means that capital gains were slightly negative. ${ }^{90}$ This pattern changes after 1900, when the market price series grows at a faster rate than the issuance price series. By 1914, the issuance price series decreases to around 17\% of GDP, while the market price series increases to around 25\% of GDP. The stabilization after 1900 may

\footnotetext{
${ }^{89}$ Nominal GDP comes from series Ca184 of Carter et al. (2006). Since the original series was in pounds sterling, the GDP data was also converted to pounds.

90 This is consistent with Wilkins (2009): "in the mid-1890s, 60 to 70 percent of the capital stock of American railroads was paying no dividends, and key railroads were in receivership."
} 
be a consequence of the cooling of the American railway sector. Taking into account the whole period until 1900, capital gains were not large. After 1900 capital gains increase and reach a cumulative value of around 10\% of GDP by 1914 .

GR (2014) find that capital gains for US net external assets amount to close to 5\% of GDP in the period 2001-2010 (and much lower from 1970 to 2000). Although not stated directly by the authors, the increase in the importance of the valuation effect seems to be a direct consequence of the opening of financial markets that happened especially in the last quarter of the twentieth century, a reversal of the trend after the Great Depression. The relevance of valuation effects for the period before the First World War is a testimony to the degree of market integration at the beginning of the twentieth century. Valuation effects were already economically large for the US and UK, at least in terms of portfolio liabilities. The result is expected, in the sense that the US was an emerging market importing capital from Britain.

Figure 21 compares the market price series (both in levels and as a percentage of GDP) to the series compiled by Lane and Milesi-Ferretti (2007, starting from 1970) and to GR (2007, from 1952). US external liabilities as a percentage of GDP were actually higher in 1914 than in 1952 or 1970. Since two world wars and the ascension of the US as main global creditor marked the period between these years, the decrease of external liabilities seems adequate. Finally, Table 6: US External Liabilities (USD MM): Comparison to figures from Lewis (1975) compares the issuance price series with estimates from Lewis (1975), the only other existing source for the US external position during the pre-1914 period. ${ }^{91}$ The new estimates are

${ }^{91}$ Davis and Cull (2002) update Lewis' calculations, but the overall magnitude is similar. 
usually lower than the original source, which is natural, given that this section's sample only considers railway securities bought by British investors. Moreover, the numbers from Lewis (1975) prior to 1914 include direct investment (which amounted to one quarter of portfolio investment in 1914). ${ }^{92}$ Since the collection of data for the new series starts in 1869 , the figure for that year seems to be problematic.

\footnotetext{
${ }^{92} \mathrm{~A}$ further cross-check will be implemented by using the data regarding dividends and coupon payments for each security. A comparison with the income account of the US is possible. In this particular comparison, the issue of the IMM taking in account the total capital of American railways, and not only the capital traded in the LSE can be problematic.
} 

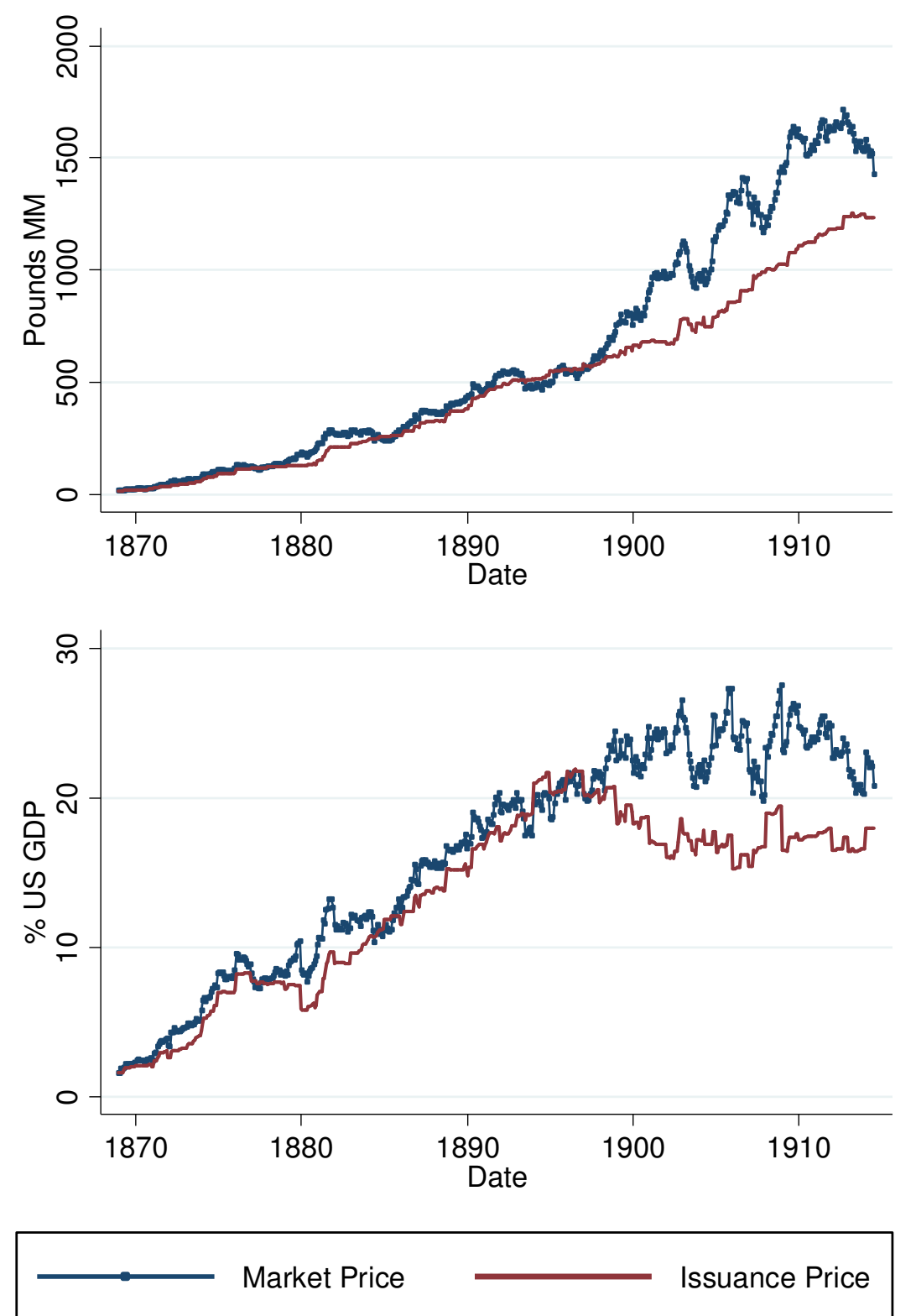

Figure 20: New series for American International Liabilities. 


\begin{tabular}{ccc}
\hline Year & Lewis (1975) & New Series \\
\hline 1869 & $1390 *$ & 137 \\
1897 & $3145 *$ & 2834 \\
1908 & $6000 *$ & 5000 \\
1914 (June 30) & 5440 & 7490 \\
\hline
\end{tabular}

Table 6: US External Liabilities (USD MM): Comparison to figures from Lewis (1975). Numbers with asterisks indicate that direct investment is included.

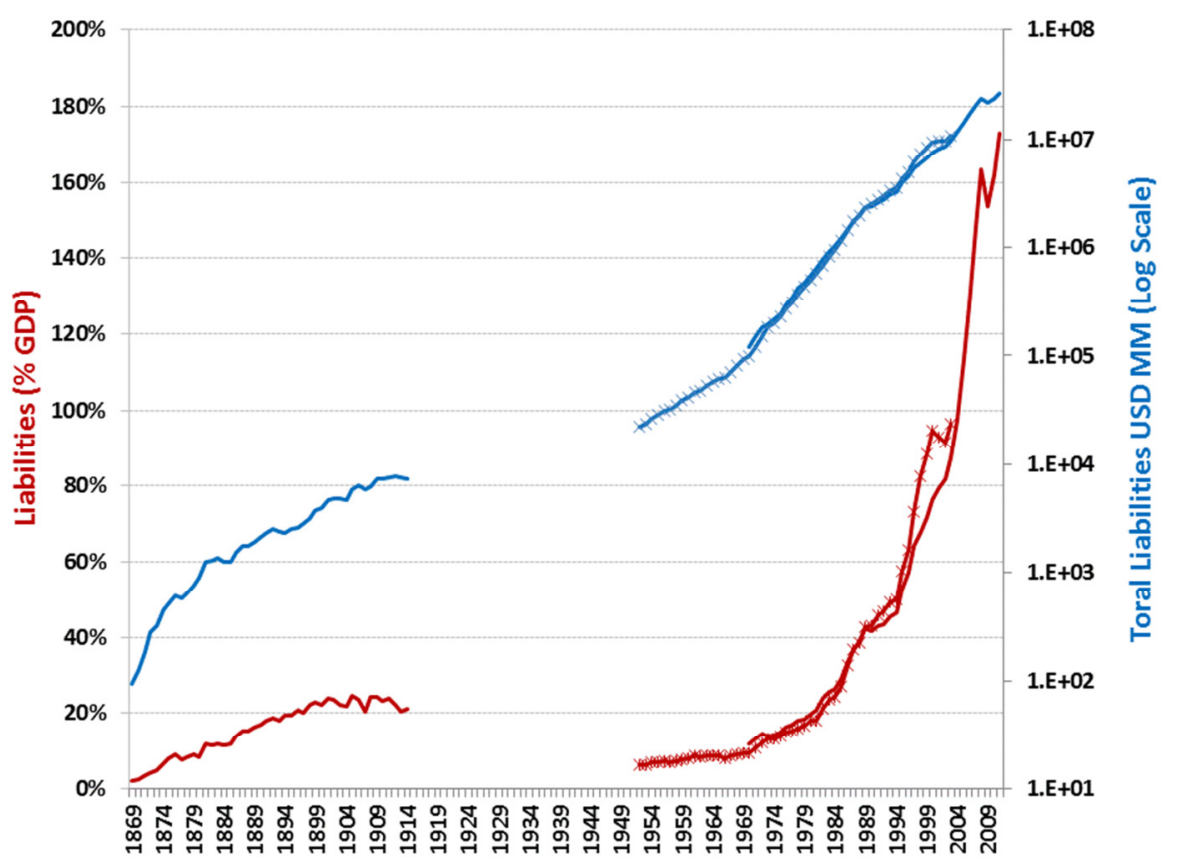

Figure 21: Comparison with series from Lane and Milesi-Ferretti (2007) and GR (2007). (In black and white charts, the right-hand side axis corresponds to the upper set of (interrupted) lines). 


\section{A.2 Technical Appendix}

A2.1 Series under the same amount of capital

Securities 30238 and 30241 had the capital value merged from March 1873 to November 1887. The original issuance of 30238 was GBP 800,000 and for 30241 was GBP 2 million, but these values decreased over time because of redemptions related to sinking funds. Both were sterling bonds from Baltimore and Ohio, but 30238 with maturity of 1895 and 30241 with maturity of 1902 . I split the values by using the values of the independent series after December 1887 and by making assumptions for the values before that. I also used the prices and paid values of 30238 to 30241 from March 1873 to April 1874. The information came from the Stock Exchange Year Book of 1883.

I used the values for February 1876 to backtrack the values of 33234, 33236, 33237 from January1869 to January 1876.

For 33750 and 33752, the value of USD 20MM from January 1869 to April 1871 referred to the whole amount of liabilities in the form of securities of the firm, including bonds detained by the State of Pennsylvania (USD 6,232,754.93) that probably were not negotiated in the market (The Economist, December 121868 Page 1436). The value of the series after May 1874 seems to be the most accurate one, but I adopted the USD 5MM as close enough.

For securities 32027, 32046 and 34676, the value of March 1870 was used as reference for April and May of 1870.

For securities 32780, 32801 and 32803, the value of August/1873 was used as reference to February to July of 1873 (since January/1873 in the case of 32801). 
I determined that series $30155,31479,31481,31482,32990$ and 35149 were of extraordinary nature and hence we considered only the companion securities. Respectively: 30153, 33267, 31477, 31477, 32991 and 30204.

\section{A2.2 Determination of currency}

\begin{tabular}{|l|l|}
\hline 30204 & Atlantic \& Gt. Westn. Do 7\% do (guar. By Erie) Pounds \\
\hline 30979 & $\begin{array}{l}\text { Chicago St Paul \& Kansas 1st mort. 5 \% bonds red. After 1896 at 105 } \\
\text { Dollars / Fall in June1893 is due to restructuring. See manual of Statistics } \\
1895, \text { page 58. }\end{array}$ \\
\hline 32199 & Illinois Central Railroad 5\% Sterling Sinking Fund Bond, before 1903 \\
\hline 32393 & $\begin{array}{l}\text { Lehigh Valley 6 \% Consolidated Mortgage "A". Pounds / IMM March } \\
1882 \text { and 1902 Moody's Manual of Corporation Securities Page 431 }\end{array}$ \\
\hline 33753 & $\begin{array}{l}\text { Pennsylvania Do general Mortgage 6 per cent. Sterling 1910 Dollars until } \\
\text { Dec. 1882, pounds after. The value is different because the mortgage was } \\
\text { split in 3 securities with the same total value (two of them probably went } \\
\text { to the US). The breakdown can be found at page 29 of the The } \\
\text { Pennsylvania Railroad Company Annual Report from 1902. }\end{array}$ \\
\hline 35039 & $\begin{array}{l}\text { Philadelphia and Erie Do 6\% General Mortgage, 1920 (issued at 87 1/2). } \\
\text { Pounds / After October 1895 dollars }\end{array}$ \\
\hline Allegheny Valley Rail. 6\% Gold or 7\% Currency Mort. 1910 Dollars / \\
\hline 3788
\end{tabular}


A2.3 Securities corrections

\begin{tabular}{|c|c|c|}
\hline Old Code & New Code & Period and Notes \\
\hline 31489 & 31490 & $\begin{array}{c}\text { December } 1907 \text { - July } \\
1914\end{array}$ \\
\hline 31490 & 31489 & $\begin{array}{c}\text { December } 1907 \text { - July } \\
1914\end{array}$ \\
\hline 33262 & 31471 & \\
\hline 33265 & 31477 & \\
\hline 35183 & 33266 & $\begin{array}{l}\text { March } 1879 / 33266 \text { is the } \\
\text { fusion of } 31476 \text { and } 31478\end{array}$ \\
\hline 35184 & 33270 & \\
\hline 33280 & 33266 & $\begin{array}{c}33266 \text { merges into } 33270 \\
\text { in August } 1883\end{array}$ \\
\hline 33268 & 31479 & \\
\hline 33663 & 33660 & March and April 1888 \\
\hline 33762 & 33751 & $\begin{array}{c}\text { December } 1887 \text { and } \\
\text { January } 88\end{array}$ \\
\hline 34520 & 34504 & \\
\hline 34518 & 34505 & \\
\hline 34515 & 34503 & \\
\hline 34446 & 34447 & April 1894 - May 1905 \\
\hline 30167 & 30166 & October 1911 - July 1914 \\
\hline 30211 & 30213 & $\begin{array}{c}\text { May } 1880 \text { - September } \\
1880\end{array}$ \\
\hline 31490 & 31477 & May 1900 - July 1914 \\
\hline 33271 & 31489 & April 1879 - April 1900 \\
\hline 31469 & 33272 & $\begin{array}{c}\text { January } 1883 \text { - March } \\
1896\end{array}$ \\
\hline 33272 & 31480 & April 1879 - March 1896 \\
\hline 30347 & 30247 & January 1894 - June 1894 \\
\hline 30483 & 30841 & $\begin{array}{c}\text { January } 1883 \text { - December } \\
1899 \\
\end{array}$ \\
\hline 30973 & 30958 & January 1912 - July 1914 \\
\hline 32230 & 32229 & $\begin{array}{c}\text { January } 1874 \text { - January } \\
1882 \text { / Indicated by Yale } \\
\text { ICF }\end{array}$ \\
\hline 33296 & 30187 & $\begin{array}{c}\text { November } 1880 \text { - June } \\
1881 \\
\end{array}$ \\
\hline 33291 & 30192 & $\begin{array}{c}\text { November } 1880 \text { - June } \\
1881\end{array}$ \\
\hline 33761 & 33755 & $\begin{array}{c}\text { Feb. } 1878 \text { - April } 81 \text { / Dec. } \\
81 \text { - Dec. } 82\end{array}$ \\
\hline 33755 & 33761 & $\begin{array}{l}\text { Oct. } 1870 \text { - Dec. } 75 \text { / Feb. } \\
78 \text { - April } 81 \text { / Dec. } 81 \text { - }\end{array}$ \\
\hline
\end{tabular}




\begin{tabular}{|c|c|c|}
\hline & & Dec 82 \\
\hline 32867 & 32714 & $\begin{array}{c}\text { September } 1871 \text { - July } \\
1891\end{array}$ \\
\hline 30423 & 31445 & $\begin{array}{l}\text { May } 1901 \text { - December } \\
1906 / \text { Eastern of } \\
\text { Massachusetts becomes } \\
\text { Boston and Maine }\end{array}$ \\
\hline 31616 & 31637 & Feb/1901 - Apr/01 \\
\hline 31652 & 31644 & Mar/02 \\
\hline 31649 & 31660 & Nov/01 - May/02 \\
\hline 33595 & 31645 & Apr/93 - Jan/94 \\
\hline 31652 & 31645 & Jan/03 - Jul/14 \\
\hline 31652 & 31644 & Oct/02 - Dec/02 \\
\hline 31617 & 31611 & Feb/94 - Jul/14 \\
\hline 31678 & 31674 & Jan/99 - Jul/14 (- May/99) \\
\hline 31813 & 31761 & Jan/03 - Jul/14 (- May/03) \\
\hline 31730 & 31791 & Jan/69 - Dec/79 \\
\hline 31807 & 31791 & Feb/87- Jul/14 \\
\hline 31802 & 31799 & Jan/83 - Jul/14 \\
\hline 31822 & 31809 & Jan/94 - Set/95 \\
\hline 31806 & 32363 & Aug/84 - Oct/84 \\
\hline 31082 & 31081 & Jan/Feb 95 \\
\hline 31113 & 31102 & $\mathrm{Jan} / 90-\mathrm{Jul} / 14$ \\
\hline 31114 & 31108 & Jan/90 - Set/08 \\
\hline 31192 & 31189 & May/99 - Jul/14 \\
\hline 31327 & 31324 & Set/72 - Dez/82 \\
\hline 31324 & 31327 & Nov/93 - Jun/08 \\
\hline 31467 & 31458 & Jan/08 - Jul/14 \\
\hline 31560 & 31549 & $\begin{array}{c}\text { Jan/74 - Jun/74 and Set/74 } \\
- \text { Apr/81 }\end{array}$ \\
\hline 31574 & 31547 & $\mathrm{Jan} / 83-\mathrm{Jul} / 14$ \\
\hline 30119 & 30111 & Feb/08 - Apr/08 \\
\hline 30111 & 30119 & Set/08 - Nov/08 \\
\hline 32382 & 30212 & May/1899 - Jan 1905 \\
\hline 30376 & 30375 & Jan/14 - Jul/14 \\
\hline 30375 & 30376 & Apr/14 - Jul/14 \\
\hline 30795 & 31040 & May - Jul/14 \\
\hline 31895 & 31859 & $\mathrm{Feb} / 82-\mathrm{Apr} / 82$ \\
\hline 31882 & 31872 & Dec/82 - Jul/14 \\
\hline 31891 & 31899 & Nov/89 - Sep/91 \\
\hline 31919 & 31951 & Feb/88 - Apr/88 \\
\hline 31951 & 31919 & Oct/88 - Nov/88 \\
\hline
\end{tabular}




\begin{tabular}{|c|c|c|}
\hline 31958 & 31950 & Jan/91 - Jun/91 \\
\hline 31907 & 31953 & Jan/69 - Dec/82 \\
\hline 31975 & 31992 & Apr/76 - Dec/82 \\
\hline 31976 & 31989 & Dec/12 - Jul/14 \\
\hline 31892 & 31893 & May/76 - Dec/87 \\
\hline 32107 & 32104 & Jan/93 - Jul/14 \\
\hline 32136 & 32137 & May/09 - Jul/14 \\
\hline 32180 & 32176 & Aug/90 - Jul/14 \\
\hline 32176 & 32180 & Aug/90 - Jul/14 \\
\hline 32176 & 32177 & Jun/82 - Jan/84 \\
\hline 32177 & 32176 & Jun/82 - Jan/84 \\
\hline 32373 & 32341 & Mar/95 - Apr/95 \\
\hline 32399 & 32404 & Jan/69 - Apr/76 \\
\hline 32410 & 32407 & Feb/98 - Apr/98 \\
\hline 32662 & 32647 & Sep/70 - Dec/82 \\
\hline 32650 & 32651 & $\begin{array}{c}\text { Jun/85 - Dec/85 and } \\
\text { Feb/86 - Aug/86 }\end{array}$ \\
\hline 32673 & 32678 & Jan/69 - Dec/82 \\
\hline 32675 & 32677 & Sep/76 - Dec/82 \\
\hline 32754 & 32753 & Feb/03 - Apr/03 \\
\hline 32753 & 32754 & $\mathrm{Feb} / 03-\mathrm{Apr} / 03$ \\
\hline 32749 & 32746 & Jul/72 - Dec/76 \\
\hline 32813 & 32784 & $\mathrm{Jan} / 77$ \\
\hline 32829 & 32823 & Feb/07 - Apr/07 \\
\hline 32868 & 32872 & Jul/84 - Jan/01 \\
\hline 32902 & 32904 & Aug/92 - Jun/93 \\
\hline 35017 & 32883 & Jan/79 - Aug/81 \\
\hline 32942 & 32932 & Oct/12 - Jul/14 \\
\hline 32944 & 32921 & $\begin{array}{c}\mathrm{Jan} / 13-\mathrm{Apr} / 14 \text { and } \\
\operatorname{Dec} / 13-\mathrm{Jul} / 14\end{array}$ \\
\hline 33045 & 33018 & Jan/89 - Apr/89 \\
\hline 33034 & 33029 & Mar/75 - Apr/86 \\
\hline 33050 & 33051 & Apr/98 \\
\hline 33051 & 33050 & Apr/98 \\
\hline 33044 & 33022 & Jan/83 - Sep/97 \\
\hline 33070 & 33063 & $\mathrm{Jan} / 83-\mathrm{Jul} / 14$ \\
\hline 35137 & 33100 & Jan/83 - Jun/83 \\
\hline 33184 & 33183 & Dec/85 - Jun/97 \\
\hline 33201 & 33200 & Jan/07 - Jul/14 \\
\hline 33349 & 33341 & Oct/04 - Jul/14 \\
\hline 33400 & 3451 & Sep/88 - Dec/94 \\
\hline 33457 & 33415 & Dec/95 - Mar/96 \\
\hline
\end{tabular}




\begin{tabular}{|c|c|c|}
\hline 33461 & 33435 & Jan/08 - Jul/14 \\
\hline 33433 & 33442 & Oct $/ 80-$ Dec/83 \\
\hline 33520 & 33525 and 33526 & Jan/83 \\
\hline 34690 & 33517 & $\mathrm{Feb} / 87-\mathrm{Jul} / 14$ \\
\hline 33565 & 33572 & Nov/95 - Jul/14 \\
\hline 35561 & 33564 & Jan/69 - Feb/73 \\
\hline 33599 & 35182 & Feb - Mar/76 \\
\hline 35182 & 31980 & Feb - Mar/76 \\
\hline 31980 & 33599 & Feb - Mar/76 \\
\hline 33690 & 33687 & $\begin{array}{c}\mathrm{Jan} / 81-\mathrm{Nov} / 95 \text { - (Jan/Apr } \\
95)\end{array}$ \\
\hline 33699 & 33687 & Jan/95 - Dec/99 \\
\hline 34693 & 33697 & $\begin{array}{c}\text { Feb/94 - Dec/99 - } \\
\text { (May/Nov 94) }\end{array}$ \\
\hline 33719 & 33711 & Jan/83 - Jan/89 \\
\hline 33746 & 33743 & May/82 - Nov/82 \\
\hline 33743 & 33746 & May/82 - Nov/82 \\
\hline 35110 & 33841 & $\begin{array}{c}\text { Jan/Mar/69 and May - } \\
\text { Aug/69 }\end{array}$ \\
\hline 33869 & 33867 & Jan - Apr/06 \\
\hline 33879 & 33877 & $\mathrm{Mar} / 10$ - Sep/12 \\
\hline 33985 & 33980 & Feb - Apr/74 \\
\hline 34011 & 34021 & Jan/69 - Dec/82 \\
\hline 35000 & 34059 & $\mathrm{Jan} / 86$ \\
\hline 34089 & 34088 & May - Nov/72 \\
\hline 34109 & 34114 & Jan/69 - Dec/82 \\
\hline 34198 & 34203 & Sep/82 - Dec/82 \\
\hline 34313 & 34312 & Mar - Apr/89 \\
\hline 34356 & 34346 & Jan/83 - Sep/88 \\
\hline 34456 & 34460 & Jan/1901 - Apr/1906 \\
\hline 34497 & 34495 & Feb, Apr / 95 \\
\hline 34495 & 34497 & Oct- Nov/95 \\
\hline 34547 & 34644 & Mar/1904 \\
\hline 34644 & 34547 & Mar/1904 \\
\hline 34601 & 34603 & Jan/95 - Jul/14 \\
\hline 35157 & 30546 & Dec/93 - Nov/94 \\
\hline 34657 & 30489 & Aug/96 - Feb/97 \\
\hline 35198 & 34660 & Dec/72 - Jan/73 \\
\hline 34660 & 30368 & $\mathrm{Dec} / 72-\mathrm{Feb} / 73$ \\
\hline 30623 & 35087 & Nov/82 \\
\hline 35107 & 31268 & Mar, May - Aug/69 \\
\hline 35086 & 31276 & Mar/72 - Dec/89 \\
\hline
\end{tabular}




\begin{tabular}{|c|c|c|}
\hline 31274 & 31276 & Jan/90 - Dec/06 \\
\hline 35100 & 31341 & Jan/69 - Nov/71 \\
\hline 31344 & 31342 & Jan/69 - Nov/71 \\
\hline 35103 & 31415 & Jan/69 - Dec/69 \\
\hline 31422 & 31415 & Jan/77 - Jul/84 \\
\hline 34653 & 31611 & Jan/69 - Dec/82 \\
\hline 31772 & 31750 & Apr/74 \\
\hline 32056 & 34676 & Jun/69 \\
\hline 34676 & 32056 & Jun/69 \\
\hline 35538 & $\mathrm{X}$ & \\
\hline 32335 & 32365 & Jan/69 - Dec/79 \\
\hline 35003 & 32800 & May/81 - Jun/83 \\
\hline 35105 & 32787 & Jan - Apr/73 \\
\hline $35203+35204$ & 32847 & Jan - Feb/69 \\
\hline 32814 & 31688 & From Aug/1897 \\
\hline 32813 & 31683 & From Aug/1897 \\
\hline 32808 & 31684 & From Aug/1897 \\
\hline 32803 & 31701 & From Aug/1897 \\
\hline 32801 & 31700 & From Aug/1897 \\
\hline 32800 & 31687 & From Aug/1897 \\
\hline 32798 & 31693 & From Aug/1897 \\
\hline 32799 & 31682 & From Aug/1897 \\
\hline 32790 & 31691 & From Aug/1897 \\
\hline 32789 & 31690 & From Aug/1897 \\
\hline 32788 & 31681 & From Aug/1897 \\
\hline 32786 & 31702 & From Aug/1897 \\
\hline 32782 & 31692 & From Aug/1897 \\
\hline 32780 & 31699 & From Aug/1897 \\
\hline 32777 & 31697 & From Aug/1897 \\
\hline 32775 & 31689 & From Aug/1897 \\
\hline 32766 & 31698 & From Aug/1897 \\
\hline 32765 & 31696 & From Aug/1897 \\
\hline 32809 & 31685 & From Aug/1897 \\
\hline 32816 & 31686 & From Aug/1897 \\
\hline 32818 & 31694 & From Aug/1897 \\
\hline 32818 & 31694 & From Aug/1897 \\
\hline 32796 & 31695 & From Aug/1897 \\
\hline 32819 & 31724 & From Aug/1897 \\
\hline 32817 & 31723 & From Aug/1897 \\
\hline 35167 & 33199 & May / Jun 02 \\
\hline 34540 & 30172 & Jan/83 - Sep/89 \\
\hline
\end{tabular}




\begin{tabular}{|c|c|c|}
\hline 30524 & 30815 & Aug/02 - Oct/08 \\
\hline 30807 & 30809 & Aug/02 - Oct/08 \\
\hline 30525 & 30799 & $\mathrm{Aug} / 02$ - Oct/08 \\
\hline 30808 & 30513 & Nov/08 - Jul/14 \\
\hline 31257 & 31292 & Jan/07 - Jul/14 \\
\hline 31155 & 32140 & Oct/98 - Feb/02 \\
\hline 31411 & 32728 & Jul/82 - Apr/88 \\
\hline 31409 & 32727 & Aug/81 - Apr/83 \\
\hline 31410 & 32729 & $\mathrm{Dec} / 82-\mathrm{Apr} / 83$ \\
\hline 31503 & 33439 & Jan/69 - Dec/82 \\
\hline 31504 & 33440 & Jan/69 - Dec/82 \\
\hline 32076 & 32065 & Jun/89 - Jul/14 \\
\hline 30051 & 30052 & Oct/91 - Dec/91 \\
\hline 30052 & 30051 & Oct/91 - Dec/91 \\
\hline 30095 & 30669 & Jan/69 - Dec/82 \\
\hline 30306 & 30309 & May/95 - Jul/14 \\
\hline 30720 & 30704 & Jan/85 - Sep/85 \\
\hline 31075 & 31071 & Dec/09 \\
\hline 31293 & 31277 & Mar/00 - Dec/06 \\
\hline 31302 & 31305 & Jan/73 - Oct/80 \\
\hline 31417 & 31414 & Jan/69 - Dec/70 \\
\hline 33695 & 33691 & Feb/88 - Dec/99 \\
\hline 35127 & 33841 & May/76 - Set/76 \\
\hline 31983 & 33840 & May/76 - Feb/92 \\
\hline 31998 & 33843 & May/76 - Feb/92 \\
\hline 31477 & 31822 & Aug/77 - Jan/92 \\
\hline 32456 & 31780 & $\begin{array}{c}\mathrm{Jan} / 69-\mathrm{Dec} / 71 \\
\mathrm{Feb} / 92-\mathrm{Jul} / 14\end{array}$ \\
\hline 32457 & 31764 & $\begin{array}{c}\mathrm{Jan} / 69-\mathrm{Dec} / 71 \\
\mathrm{Feb} / 92-\mathrm{Jul} / 14\end{array}$ \\
\hline 32458 & $\mathrm{X}$ & \\
\hline 35164 & $\mathrm{X}$ & \\
\hline 35185 & 33484 & Mar/79 \\
\hline 33486 & 33502 & May/71 - Jul/71 \\
\hline 33473 & 33502 & Mar/71 - Apr/71 \\
\hline 35182 & 32001 & Jan/76 - Apr/76 \\
\hline 31266 & 31989 & Jan/69 - Feb/75 \\
\hline 31267 & 31977 & Sep/69- Feb/75 \\
\hline 31265 & 31997 & $\mathrm{Jan} / 69-\mathrm{Feb} / 75$ \\
\hline 33599 & 31997 & Mar/75 - Apr/76 \\
\hline 33598 & 31264 & Mar/75 - May/76 \\
\hline 31264 & 31992 & Jan/69 - Mar/76 \\
\hline
\end{tabular}




\begin{tabular}{|c|c|c|}
\hline & & (Apr, May discarded) \\
\hline 34363 & 34364 & Dec/79 \\
\hline 35205 & 34359 & Jan/69 \\
\hline 30513 & 30519 & Jun/89 - Jul/14 \\
\hline 31094 & 34663 & $\mathrm{Feb} / 13-\mathrm{Jul} / 14$ \\
\hline 31595 & 31580 & Jan/98 - Feb/99 (Prices) \\
\hline 31580 & 31595 & Jan/98 - Feb/99 (Prices) \\
\hline 31699 & 32776 & $\mathrm{Jan} / 73$ \\
\hline 31730 & 31791 & Jan/69 - Feb/69 \\
\hline 35177 and 35178 & 33151 & Jan/69 - Mar/69 \\
\hline 33331 & 33329 & Dec/87-May/90 \\
\hline 11029 & 11028 & Jan/69 - Dec/70 \\
\hline 10912 & 10909 & May/88 - Dec/02 \\
\hline 11072 & 11071 & Oct/10 - Dec/11 \\
\hline 11069 & 11071 & Jan/13 - Jul/14 \\
\hline 32553 & 32547 & Feb/Mar 94 \\
\hline 32558 & 32553 & Apr/94 - Jul/14 \\
\hline 32553 & 32558 & Apr/94 - Jul/14 \\
\hline 10224 & 10229 & Mar/1878 - Out/1902 \\
\hline 10014 & 10231 & Mar/86 - Feb/96 \\
\hline 10232 & 10014 & Jan/83 - Feb/86 \\
\hline 10566 & 10523 & Feb/02 - Out/02 \\
\hline 10820 & 10821 & Jan/96 - Oct/98 \\
\hline 10264 & 10014 & Mar/86 - Jun/10 \\
\hline 10671 & 10601 & Jan/92 - Jul/14 \\
\hline 10806 & 10794 & Feb/88 - Dec/05 \\
\hline 11007 & 10930 & Dec/07 - Sep/10 \\
\hline 11005 & 10930 & Oct $/ 10-$ Sep/13 \\
\hline 11421 & 11420 & Nov/11 - Dec/90 \\
\hline 11441 & 11450 & Jan/77 - Dec/77 \\
\hline 11520 & 11512 & Jan/69 - Dec/70 \\
\hline 11527 & 11526 & $\operatorname{Jan} / 71-\operatorname{Dec} / 72$ \\
\hline 11533 & 11534 & Jan/84 - Jan/97 \\
\hline 11530 & 11529 & Jan/07 - Jul/14 \\
\hline 11557 & 11555 & $\mathrm{Feb} / 11-\mathrm{Dec} / 12$ \\
\hline 11647 & 11618 & Jan/77 - Dec/83 \\
\hline 11643 & 11612 & Jan/77 - Jan/91 \\
\hline 11642 & 11638 & Jan/79- Dec/87 \\
\hline 11669 & 11662 & Jan/69 - Dec/70 \\
\hline 11820 & 11813 & Sep/1906 - Dec/07 \\
\hline 11848 & 11855 & Jan/97 - Jul/97 \\
\hline
\end{tabular}




\begin{tabular}{|c|c|c|}
\hline 10011 & 10007 & Jan/69- Dec/70 \\
\hline 10012 & 10005 & Jan/69 - Dec/70 \\
\hline 11877 & 10006 & Jan/69 - Dec/70 \\
\hline 11890 & 11888 & Feb/88 - Jul/88 \\
\hline 11889 & 11907 & Sep/88 - Jan/89 \\
\hline 12243 & 12232 & Jan/69 - Aug/71 \\
\hline 12385 & 12383 & Apr/74 - Dec/78 \\
\hline 12319 & 12302 & Aug/90 - Dec/90 \\
\hline 12297 & 12319 & Aug/90 - Jan/03 \\
\hline 12496 & 12333 & Jan/79 - Jun/94 \\
\hline 12509 & 12331 & Mar/83 - Oct/89 \\
\hline 12329 & 12336 & Jan/71 - Jan/73 \\
\hline 11918 & 12456 & Nov/71 - Dec/71 \\
\hline 11917 & 11919 & Jan/69 - Dec/70 \\
\hline 12426 & 12408 & Jan/69 - Dec/70 \\
\hline 12428 & 12410 & Feb/69 - Dec/70 \\
\hline 12403 & 12411 & Jan/69 - Dec/70 \\
\hline 12427 & 12403 & Apr/69 - Dec/70 \\
\hline 12412 & 11537 & Feb/71 - Jul/78 \\
\hline 12443 & 12442 & Aug/90 \\
\hline 10906 & 11338 & Sep/88 - Aug/89 \\
\hline 11278 & 11348 & Jan/69 - Dec/71 \\
\hline 11984 & 11365 & Jan/07 - Jul/14 \\
\hline 11336 & 10902 & Sep/89-Apr/94 \\
\hline 12074 & 12868 & Dec/69 - Jan/74 \\
\hline 10188 & $\mathrm{X}$ & \\
\hline & & \\
\hline & & \\
\hline
\end{tabular}




\section{A3 Robustness for Calculation of Exorbitant Privilege}

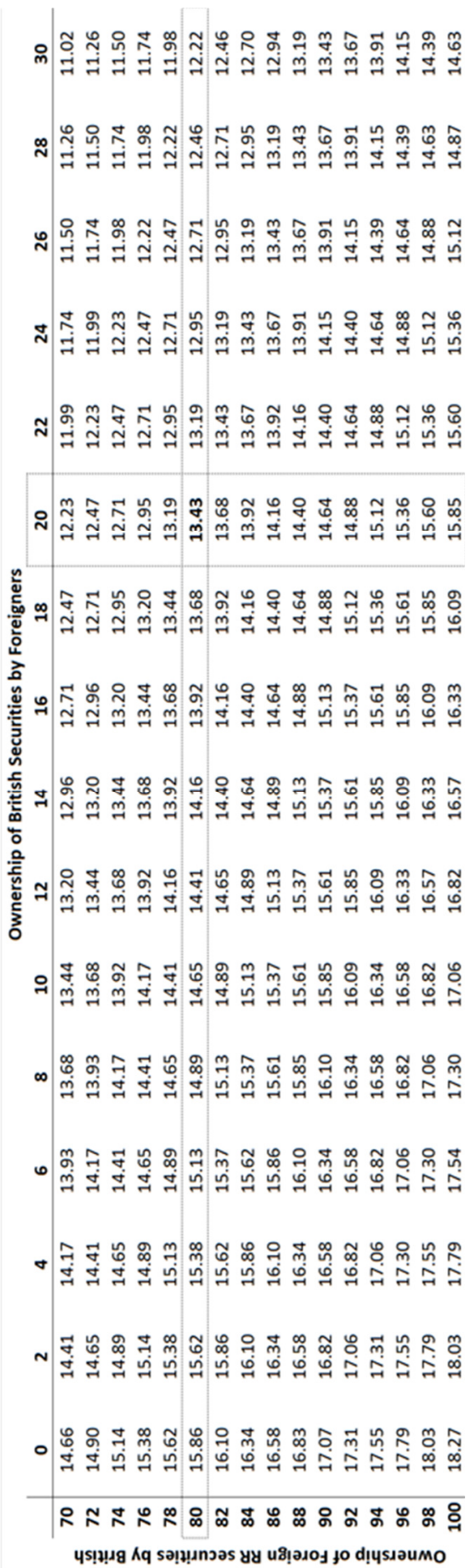

Table 7: Exorbitant Privilege for the period 1869-1914 (\% of GDP): Variation in the ratio of ownership of British and Foreign securities. 


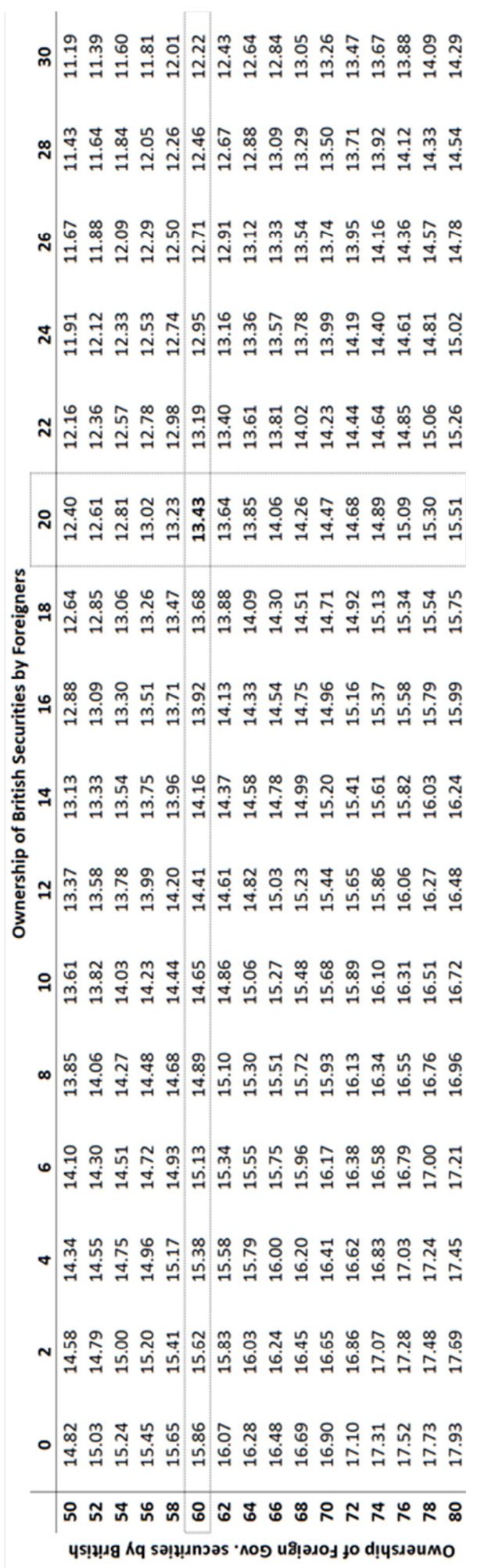

Table 8: Exorbitant Privilege for the period 1869-1914 (\% of GDP): Variation in the ratio of ownership of British and Foreign securities. 


\section{Bibliography}

Abreu, Marcelo de Paiva. 2006. "Brazil as a debtor, 1824--19311." The Economic History Review (Wiley Online Library) 59 (4): 765-787.

Abreu, Marcelo de Paiva. 2000. "British business in Brazil: maturity and demise (1850-1950)." Revista Brasileira de Economia (SciELO Brasil) 54 (4): 383413.

Araujo, Juliana Dutra, David Antonio, Carlos van Hombeck, and Chris Papageorgiou. 2015. "Non-FDI Capital Inflows in Low-Income Developing Countries: Catching the Wave?" IMF Working Paper No. 15/86, International Monetary Fund.

Borio, Claudio, and Piti Disyatat. 2015. "Capital flows and the current account: Taking financing (more) seriously." BIS Working Paper No. 525, Bank for International Settlements.

Carter, Susan B, Scott Sigmund Gartner, Michael R Haines, Alan L Olmstead, Richard Sutch, and Gavin Wright. 2006. Historical statistics of the United States. Cambridge University Press New York.

Chabot, Benjamin R, and Christopher J Kurz. 2010. "That's Where The Money Was: Foreign Bias and English Investment Abroad, 1866--1907." The Economic Journal (Wiley Online Library) 120 (547): 1056-1079.

Crafts, Nicholas FR. 1979. "Victorian Britain did fail." The Economic History Review (Wiley Online Library) 32 (4): 533-537.

Curcuru, Stephanie E, Charles P Thomas, and Francis E Warnock. 2008. "Current Account Sustainability and Relative Reliability." NBER International Seminar on Macroeconomics. 67-109.

Curcuru, Stephanie E, Charles P Thomas, and Francis E Warnock. 2013. "On returns differentials." Journal of International Money and Finance (Elsevier) 36: 125.

Curcuru, Stephanie E, Tomas Dvorak, Francis E Warnock, and others. 2008. "CrossBorder Returns Differentials." The Quarterly Journal of Economics (MIT Press) 123 (4): 1495-1530.

Davis, Lance Edwin, and Robert A Huttenback. 1986. Mammon and the pursuit of Empire: The political economy of British imperialism, 1860-1912. Cambridge University Press.

Davis, Lance Edwin, and Robert E Gallman. 2001. Evolving Financial Markets and International Capital Flows: Britain, the Americas, and Australia, 1865-1914. Cambridge University Press. 
Davis, Lance Edwin, and Robert J Cull. 2002. International capital markets and American economic growth, 1820-1914. Cambridge University Press.

Dimsdale, N, S Hills, and R Thomas . 2015. "Three Centuries of Data - Version 2.1." Bank of England.

Edelstein, Michael. 1982. Overseas investment in the age of high imperialism: the United Kingdom, 1850-1914. Columbia University Press New York.

Edlinger, Cécile, Maxime Merli, and Antoine Parent. 2013. "An Optimal World Portfolio on the Eve of World War I: Was There a Bias to Investing in the New World Rather Than in Europe?" The Journal of Economic History (Cambridge Univ Press) 73 (02): 498-530.

Eichengreen, Barry J. 1998. Globalizing capital: a history of the international monetary system. Princeton University Press.

Eichengreen, Barry, Ricardo Hausmann, and Ugo Panizza. 2007. "Currency mismatches, debt intolerance, and the original sin: Why they are not the same and why it matters." In Capital controls and capital flows in emerging economies: Policies, practices and consequences, 121-170. University of Chicago Press.

Forbes, Kristin J. 2010. "Why do foreigners invest in the United States?" Journal of International Economics (Elsevier) 80 (1): 3-21.

Foreman-Peck, James. 1989. "Foreign Investment and Imperial Exploitation: Balance of Payments Reconstruction for Nineteenth-Century Britain and India." The Economic History Review (Wiley on behalf of the Economic History Society) 42 (3): 354-374.

Goetzmann, William N, and Andrey D Ukhov. 2006. "British investment overseas 1870--1913: a modern portfolio theory approach." Review of Finance (Oxford University Press) 10 (2): 261-300.

Gohrband, Christopher A, and Kristy L Howell. 2015. "US International Financial Flows and the US Net Investment Position." Measuring Wealth and Financial Intermediation and Their Links to the Real Economy (University of Chicago Press) 73: 231.

Gourinchas, Pierre-Olivier, and Hélene Rey. 2014. External Adjustment, Global Imbalances, Valuation Effects. Vol. 4, chap. 10 in Handbook of International Economics, edited by Kenneth Rogoff Elhanan Helpman and Gita Gopinath, 585-645. Elsevier.

Gourinchas, Pierre-Olivier, and Hélene Rey. 2007. "From world banker to world venture capitalist: US external adjustment and the exorbitant privilege." In $G 7$ 
Current Account Imbalances: Sustainability and Adjustment, 11-66. University of Chicago Press.

Gourinchas, Pierre-Olivier, Hélene Rey, and Nicolas Govillot. 2010. "Exorbitant Privilege and Exorbitant Duty."

Grossman, Richard S. 2002. "New indices of British equity prices, 1870--1913." The Journal of Economic History (Cambridge Univ Press) 62 (01): 121-146.

Grossman, Richard S. 2015. "Bloody foreigners! Overseas equity on the London Stock Exchange, 1869-1929." The Economic History Review (Wiley Online Library) 68 (2): 471--521.

Habib, Maurizio. 2010. Excess returns on net foreign assets: the exorbitant privilege from a global perspective. ECB Working Paper No. 1158, Frankfurt:

European Central Bank.

Hausmann, Ricardo, and Eduardo Fernandez-Arias. 2000. "Foreign Direct Investment: Good Cholesterol?" Tech. rep., Inter-American Development Bank, Research Department.

Hausmann, Ricardo, and Federico Sturzenegger. 2006. "Global Imbalances or Bad Accounting? The Missing Dark Matter in the Wealth of Nations." Tech. rep., Harvard University, John F. Kennedy School of Government.

Hume, David. 1752. "Of the balance of trade." The gold standard in theory and history 330-341.

Imlah, Albert Henry. 1958. Economic Elements in the Pax Britannica: Studies in British Foreign Trade in the Nineteenth Century. Harvard University Press Cambridge, MA.

Jones, Matthew T, and Maurice Obstfeld. 2004. "Saving, Investment, and Gold: A Reassessment of Historical Current Account Data." Money, Capital Mobility, and Trade: Essays in Honor of Robert A. Mundell (MIT Press) 303.

Kennedy, William P. 1974. "Foreign investment, trade and growth in the United Kingdom, 1870--1913." Explorations in economic history (Elsevier) 11 (4): 415-444.

Keynes, John Maynard. 2004. The economic consequences of the peace. Courier Dover Publications.

Kindersley, Robert. 1929. "A New Study of British Foreign Investments." The Economic Journal (JSTOR) 8-24.

Lane, Philip R, and Gian Maria Milesi-Ferretti. 2007. "A global perspective on external positions." In $G 7$ current account imbalances: sustainability and adjustment, 67-102. University of Chicago Press. 
Lane, Philip R, and Gian Maria Milesi-Ferretti. 2007. "The external wealth of nations mark II: Revised and extended estimates of foreign assets and liabilities, 1970--2004." Journal of international Economics (Elsevier) 73 (2): 223-250.

Lane, Philip R, and Gian Maria Milesi-Ferretti. 2001. "The external wealth of nations: measures of foreign assets and liabilities for industrial and developing countries." Journal of international Economics (Elsevier) 55 (2): 263-294.

Lane, Philip R, and Gian Maria Milesi-Ferretti. 2009. "Where did all the borrowing go? A forensic analysis of the US external position." Journal of the Japanese and international Economies (Elsevier) 23 (2): 177-199.

Lewis, Cleona. 1975. "America's Stake in International Investments (Washington, DC: Brookings Institution, 1938)." I63-I64 45-46.

Lindert, Peter H. 1969. Key currencies and gold, 1900-1913. International Finance Section, Princeton University.

McCauley, Robert N. 2015. "Does the US dollar confer an exorbitant privilege?" Journal of International Money and Finance (Elsevier) 57: 1-14.

McCloskey, Donald N. 1970. "Did Victorian Britain Fail?" The Economic History Review (Wiley Online Library) 23 (3): 446-459.

Meissner, Christopher M, and Alan M Taylor. 2008. "Losing our marbles in the new century? The great rebalancing in historical perspective." In Global Imbalances and the Evolving World Economy. Federal Reserve Bank of Boston.

Mitchell, B R. 1988. British Historical Statistics. Cambridge: Cambridge University Press.

Obstfeld, Maurice, and Kenneth S Rogoff. 2005. "Global current account imbalances and exchange rate adjustments." Brookings papers on economic activity (Brookings Institution Press) 2005 (1): 67-146.

Platt, Desmond Christopher Martin. 1986. Britain's investment overseas on the eve of the First World War: the use and abuse of numbers. Macmillan Basingstoke.

Rogoff, Kenneth S., and Takeshi Tashiro. 2015. "Japan's exorbitant privilege." Journal of the Japanese and International Economies 35: 43-61.

Stone, Irving. 1977. "British direct and portfolio investment in Latin America before 1914." The Journal of Economic History (Cambridge Univ Press) 37 (03): 690-722.

- 1999. The global export of capital from Great Britain, 1865-1914: a statistical survey. Macmillan. 
Wilkins, Mira. 2009. The history of foreign investment in the United States, 19141945. Vol. 43. Harvard University Press. 